I N T ER N ATIONAL MONETARY FUND

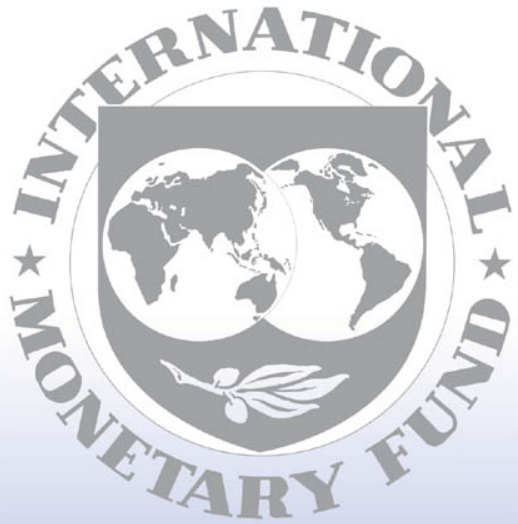

Staff

Country

Reports 


\title{
Georgia: Seventh and Eighth Reviews Under the Stand-By Arrangement, and Requests for Waivers of Nonobservance of Performance Criteria and Rephasing of Purchases- Staff Report; Staff Statement; Press Release on the Executive Board Discussion; and Statement by the Executive Director for Georgia.
}

In the context of the seventh and eighth reviews under the stand-by arrangement, and requests for waivers of nonobservance of performance criteria and rephasing of purchases, the following documents have been released and are included in this package:

- $\quad$ The staff report for the Seventh and Eighth Reviews Under the Stand-By Arrangement, and Requests for Waivers of Nonobservance of Performance Criteria and Rephasing of Purchases, prepared by a staff team of the IMF, following discussions that ended on November 10, 2010, with the officials of Georgia on economic developments and policies. Based on information available at the time of these discussions, the staff report was completed on December 23, 2010. The views expressed in the staff report are those of the staff team and do not necessarily reflect the views of the Executive Board of the IMF.

- $\quad$ A staff statement of January 12, 2011.

- $\quad$ A Press Release summarizing the views of the Executive Board as expressed during its January 12, 2011 discussion of the staff report.

- $\quad$ A statement by the Executive Director for Georgia.

The documents listed below have been or will be separately released.

Letter of Intent sent to the IMF by the authorities of Georgia*

Technical Memorandum of Understanding*

*Also included in Staff Report

The policy of publication of staff reports and other documents allows for the deletion of market-sensitive information.

Copies of this report are available to the public from

International Monetary Fund • Publication Services

$70019^{\text {th }}$ Street, N.W. • Washington, D.C. 20431

Telephone: (202) 623-7430 • Telefax: (202) 623-7201

E-mail: publications@imf.org Internet: http://www.imf.org

\author{
International Monetary Fund \\ Washington, D.C.
}




\title{
INTERNATIONAL MONETARY FUND
}

\section{GEORGIA}

\section{Seventh and Eighth Reviews Under the Stand-By Arrangement, and Requests for Waivers of Nonobservance of Performance Criteria and Rephasing of Purchases}

\author{
Prepared by the Middle East and Central Asia Department \\ (In consultation with other departments)
}

Approved by David Owen (MCD) and Dominique Desruelle (SPR)

December 23, 2010

- Background: The Sixth Review under the Stand-By Arrangement (SBA) was concluded on July 9, 2010. Access under the SBA is SDR 747.1 million (497.1 percent of quota), of which SDR 577.1 million has been disbursed. The arrangement expires June 14, 2011.

- Program Strategy: With the economic recovery gaining ground, policy targets for 2011 emphasize fiscal adjustment and an increase in Net International Reserves (NIR), in order to bolster the exit strategy.

- Team: E. Gardner (head and Senior Resident Representative), E. Martin, A. Luca (all MCD), L. Eyraud (FAD), I. Halikias (SPR), and N. Sharashidze (Resident Representative Office).

- Exchange Rate Regime: The regime is classified as "floating." A multiple currency practice (MCP), which preceded the program, arises from the fact that the official exchange rate used by the government may differ by more than 2 percent from freely determined market rates. In practice, the official and market rates have never differed by more than 2 percent since the introduction of foreign exchange auctions in March 2009, when the market rate became more flexible.

- Statistics: Economic data are broadly adequate for surveillance and program monitoring. Georgia participates in the GDDS and subscribed to the SDDS in May 2010. 
Executive Summary

I. Program Performance

II. Recent Developments.

III. Policies for 2011 and the Exit Strategy...

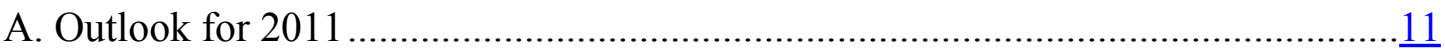

B. Fiscal Policy ........................................................................................... $\frac{12}{15}$

C. Monetary and Exchange Rate Policy ........................................................ 15

D. Financial Sector Policies ........................................................................... $\frac{16}{17}$

E. The Exit Strategy and Risks ..................................................................

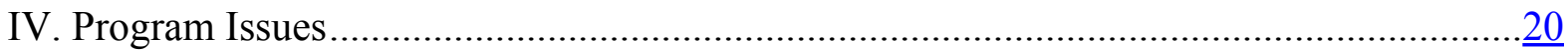

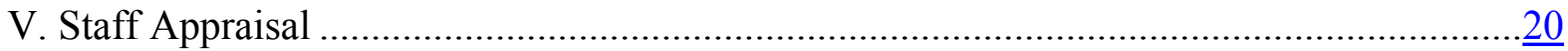

Tables

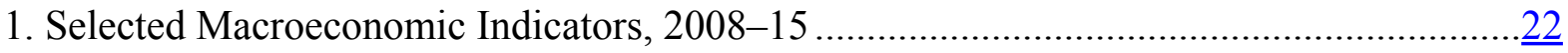

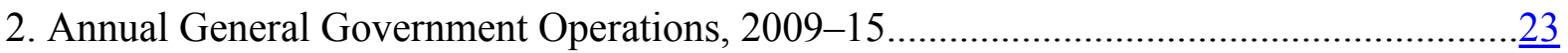

3. Quarterly General Government Operations, 2009-11 .................................................24

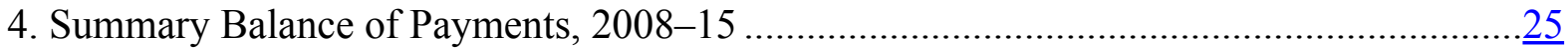

5. Accounts of the National Bank of Georgia, 2009-11 ................................................... 26

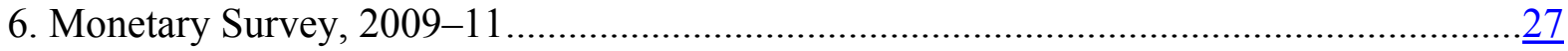

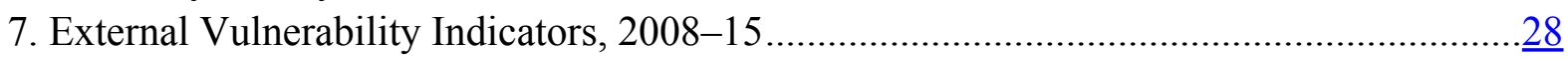

8. Indicators of Fund Credit, 2008-17 ......................................................................29

9. Schedule of Prospective Reviews and Purchases ....................................................... $\underline{30}$

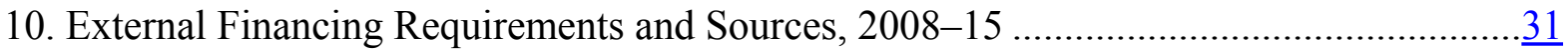

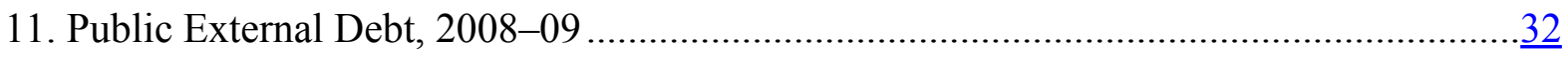

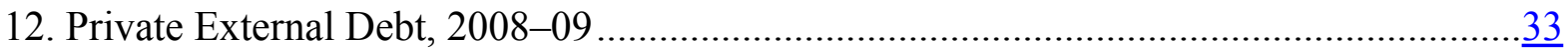

13a. External Debt Sustainability Framework, Baseline Scenario, 2007-2030 .................... 34

13b. Sensitivity Analysis for Key Indicators of Public and Publicly-Guaranteed External Debt, 2010-2030 ................................................................................................ $\frac{35}{37}$

14a. Public Sector Debt Sustainability Framework, Baseline Scenario, 2007-2030 ..............

14b. Sensitivity Analysis for Key Indicators of Public Debt, 2010-2030 .............................

Figures

1a. Indicators of Public and Publicly-Guaranteed External Debt under Alternatives Scenarios,

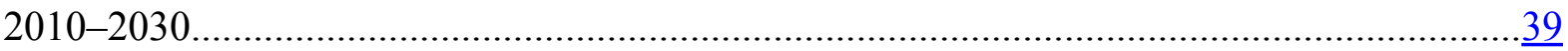

1b. Indicators of Public Debt under Alternative Scenarios, 2010-2030.............................. 40 
Box

Alternative Scenario with Lower FDI

Attachments

I. Letter of Intent

II. Revised Technical Memorandum of Understanding ..................................................... 


\section{EXeCUTIVE SUMmaRY}

Real GDP growth for 2010 has been revised up to 6.3 percent and annual CPI inflation has increased to around 10 percent, reflecting a surge in food prices. External developments have been better than expected. Since June, the lari has regained some of the ground it lost to the U.S. dollar in the first half of the year. Banks' balance sheets have strengthened further.

End-December performance criteria (PCs) are expected to be met, with the exception of the fiscal deficit and general government expenditure targets owing to the late disbursement of budget grants and disbursements under a project loan on-lent by the government, which came in earlier than the authorities anticipated. The loan disbursements by KfW-EBRD-EIB ( 0.5 percent of GDP) finance a power project, and were on-lent by the government to the responsible state enterprise. Excluding such net lending, government spending would be in line with the program. The government deficit target is similarly expected to be pushed above the program ceiling by this early loan disbursement, but also by the delay (from 2010 to 2011) in the disbursement of budget grants equivalent to 0.3 percent of GDP. The abatement of exchange rate pressures has enabled the central bank to build NIR well above program targets.

Sizeable fiscal consolidation will continue in 2011 on the back of ongoing strong growth. Real GDP is projected to grow by 4.5 percent in 2011, supported by private demand and higher private capital inflows (including FDI). The 2011 budget provides for a reduction of the deficit to 4.3 percent of GDP, from 6.8 percent in 2010, based essentially on expenditure restraint. Tax revenues would be lower relative to GDP than previously envisaged, reflecting lower estimated yields and the partial withdrawal of planned VAT measures.

Monetary policy in 2011 will aim at supporting disinflation, increasing NIR, and promoting dedollarization. The monetary program envisages an acceleration of credit and deposits growth, reflecting a resumption of financial deepening, and an increase in NIR. While the monetary program and the recent hikes in policy rates appear consistent with the objective of bringing back inflation toward 6 percent by end-2011, the authorities stand ready to tighten monetary policy further if warranted by inflation, exchange rate, and monetary developments.

Significant risks remain. Risks to growth appear balanced and are mainly related to the pace of private capital inflows, notably FDI. There are risks that balance of payment gaps could reemerge over the medium term as the result of lower-than-expected FDI, an inadequate supply response to the recovery of demand, or debt rollover pressures. Staff considers that faster fiscal adjustment in 2011 could be targeted in view of the favorable cyclical conditions and remaining risks. 


\section{Program Performance}

Georgia: Quantitative Performance Criteria (PC) and Indicative Targets, 2010

\begin{tabular}{|c|c|c|c|c|c|}
\hline \multirow[b]{2}{*}{ Performance Criteria } & \multicolumn{3}{|c|}{ Sep-10 } & \multicolumn{2}{|c|}{ Dec-10 } \\
\hline & $\mathrm{PC}$ & Adjusted PC & Actual & $\mathrm{PC}$ & Proj. \\
\hline & \multicolumn{5}{|c|}{ (Cumulative change since the beginning of 2010 , in millions of lari) } \\
\hline Ceiling on cash deficit of the general government & 867 & & 773 & 1,241 & 1,397 \\
\hline \multirow[t]{2}{*}{ Ceiling on the general government expenditures } & 5,023 & & 5,009 & 7,106 & 7,206 \\
\hline & \multicolumn{5}{|c|}{ (End-period stock, in millions of lari) } \\
\hline \multirow[t]{2}{*}{ Ceiling on net domestic assets (NDA) of the NBG $1 /$} & 506 & 564 & 513 & 714 & 470 \\
\hline & \multicolumn{5}{|c|}{ (End-period stock, in millions of U.S. dollars) } \\
\hline \multirow[t]{2}{*}{ Floor on net international reserves (NIR) of the NBG $1 /$} & 740 & 705 & 708 & 721 & 825 \\
\hline & \multicolumn{5}{|c|}{ (Cumulative change since the beginning of 2010 , in millions of U.S. dollars) } \\
\hline Ceiling on accumulation of external arrears $2 /$ & 0 & & 0 & 0 & 0 \\
\hline \multirow[t]{2}{*}{ Indicative target } & Ind. Target & & Actual & Ind. Target & Proj. \\
\hline & \multicolumn{5}{|c|}{ (Cumulative change since the beginning of 2010 , in millions of U.S. dollars) } \\
\hline $\begin{array}{l}\text { Ceiling on contracting or guaranteeing of new total external debt } \\
\text { by the public sector }\end{array}$ & 1,000 & & 646 & 1,000 & 692 \\
\hline
\end{tabular}

1. All end-September PCs were met and end-December PCs are expected to be met, with the exception of the fiscal deficit and general government expenditure targets:

- The end-December PCs on NIR and NDA are expected to be observed by wide margins, owing to lower-than-programmed foreign exchange intervention since June, and lower reserve money growth in the case of NDA; their status will be reported separately by January 6.

- The end-December PCs on the government deficit and general government expenditures are expected to be missed, owing to a delay (from 2010 to 2011) in the disbursement of budget grants amounting to GEL 56 million ( 0.3 percent of GDP) and disbursements by KfW-EBRD-EIB of a GEL100 million loan ( 0.5 percent of GDP), which came in earlier than the authorities anticipated. ${ }^{1}$ These disbursements relate to a power project loan, which is on-lent by the government to a state enterprise. Waivers of nonobservance are requested (LOI I 29) on account of these two developments, although the authorities consider that higher other revenues might compensate for the shortfall in grant disbursements.

- No offsetting action is deemed necessary to offset the increase in net lending in 2010, since the lending operation simply rephases disbursements under an existing

\footnotetext{
${ }^{1}$ While these disbursements were in line with contractual obligations, the authorities had anticipated some delays, which did not fully materialize, in meeting all the conditions attached to these loans.
} 
loan agreement, which benefits a state enterprise under commercial terms.

Furthermore, the timing of disbursements is not controlled by the government. In essence, government on-lending is equivalent to guaranteeing the external loan to the state enterprise, but, because it is channeled through the budget, it affects the deficit as measured under the program. The power project involves the construction of a high-voltage power transmission line that would enable Georgia to sell electricity to Turkey, and the commercial return from the project is expected to enable full repayment by the state enterprise.

- The end-December indicative target on the contracting and guaranteeing of external debt is expected to be met.

\section{Structural benchmarks under the program have been completed.}

\begin{tabular}{|l|c|c|c|}
\hline \multicolumn{1}{|c|}{ Georgia: Structural Benchmarks for 2010 } & \multicolumn{1}{|c|}{$\begin{array}{c}\text { Type of } \\
\text { Structural Benchmark }\end{array}$} & Time Frame & Status \\
\hline $\begin{array}{l}\text { Cabinet approval of a new medium-term } \\
\text { expenditure framework (Basic Data and Directions) } \\
\text { that includes expenditure ceilings applicable to the } \\
2011 \text { budget. }\end{array}$ & July 31, 2010 & $\begin{array}{c}\text { Structural } \\
\text { Benchmark }\end{array}$ & Observed \\
\hline $\begin{array}{l}\text { Cabinet approval of guidelines for pilot ministries to } \\
\text { introduce a programmatic approach to budgeting, in } \\
\text { line with the recommendations of the IMF technical } \\
\text { assistance report “Georgia-Advancing Program } \\
\text { Budgeting," by D. Radev, S. Flynn, L. Eyraud, and } \\
\text { S. Gurr, May 2010. }\end{array}$ & September 30, 2010 & $\begin{array}{c}\text { Structural } \\
\text { Benchmark }\end{array}$ & $\begin{array}{c}\text { Implemented } \\
\text { with delay } \\
\text { on October } \\
13 .\end{array}$ \\
\hline
\end{tabular}

\section{RECENT DEVELOPMENTS}

\section{Parliament approved a change in} the constitution that redistributes powers from the presidency to parliament and the prime minister, effective in 2013.

Parliamentary and presidential elections are scheduled for 2012 and 2013, respectively.

\section{Real GDP growth for $\mathbf{2 0 1 0}$ has been} revised up to 6.3 percent, on the back of very strong growth in the first half of the year, moderating somewhat in the second half.

While there are no reliable measures of capacity utilization, the authorities consider that the economy may be operating near

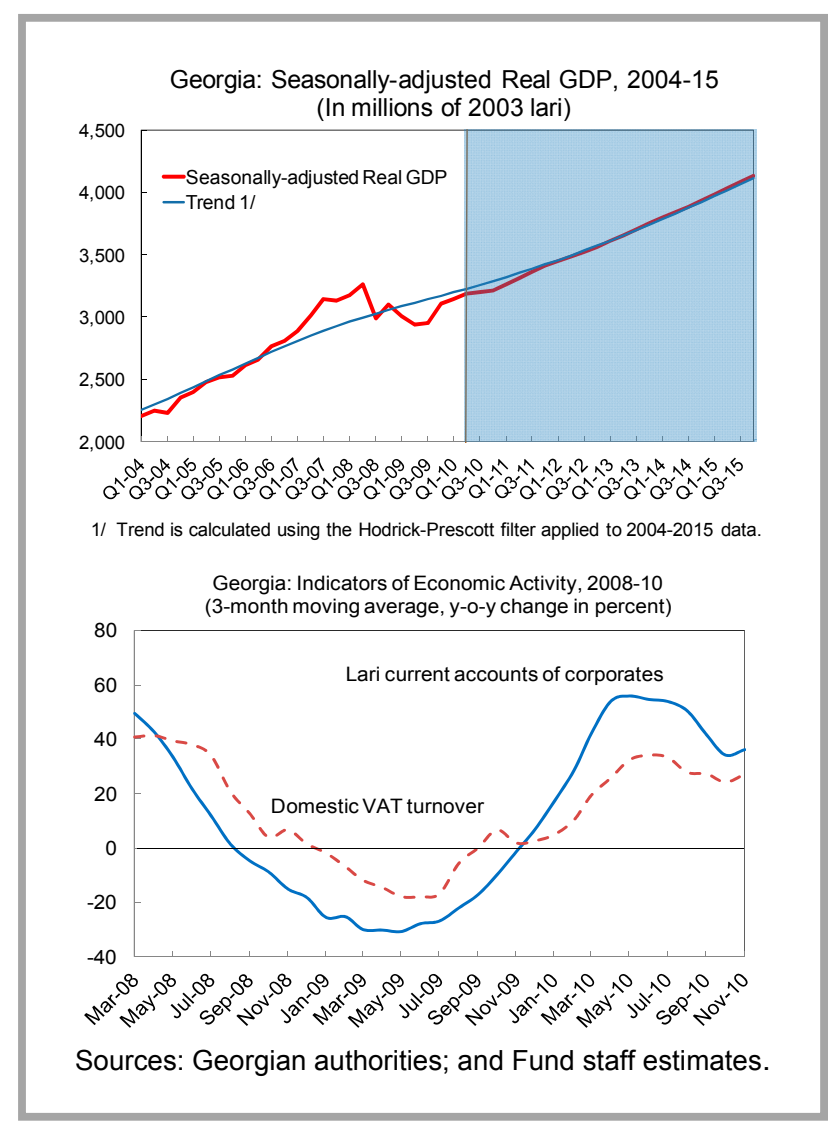

CInternational Monetary Fund. Not for Redistribution 
capacity in some sectors, when taking into account the lack of new investment during the last two years.

\section{Annual CPI inflation has surged} to around 10 percent, owing to rising food prices. This large increase in inflation reflects the heavy weight of food in the CPI basket (43 percent). Evidence of inflation in other sectors is mixed: nonfood price inflation remains very low, consistent with regional trends, while the industrial PPI has risen sharply. There is no reliable information on wages to gauge labor market pressures, but unemployment remains high (15 percent).

\section{Deposit and lending rates have} declined further, but the growth of monetary and credit aggregates has slowed. The authorities have continued to tighten monetary policy in response to higher inflation - the policy (refinancing) rate has been raised by 250 bps since June. The disconnect between the (rising) policy rate and the (declining) deposit and lending rates has reflected the lack of traction of the policy rate in a context of ample liquidity and high dollarization.

\section{The overall deficit in the $\mathbf{2 0 1 0}$} balance of payments has been revised down (by $\$ 159$ million) relative to the Sixth Review. The trade deficit is wider than expected, but the current account deficit is projected to be marginally lower

on the heels of buoyant tourism receipts (up 18 percent since 2009). Foreign exchange market developments since June (see below) point to a strong rebound of private capital inflows in the second half of the year, following a disappointing first half. The rebound of private capital inflows includes a \$250 million Georgian Railway Eurobond issue in July, but is also likely to reflect a recovery of FDI inflows - projected at around $\$ 600$ million for the year. These inflows should more than offset banking sector net flows, which are now 
estimated to be strongly negative in 2010 , owing to substantial debt prepayments and the impact of central bank liquidity injections in the first half of the year.

\section{The lari has appreciated relative to} the U.S. dollar by 6.5 percent since mid-June. Since the turnaround in foreign exchange market conditions after June, the central bank has only intervened to purchase dollars in the face of occasionally strong appreciation pressures vis-à-vis the U.S. dollar, linked in part to the weakness of the latter vis-à-vis other currencies. The projected overperformance of NIR relative to the end-December target reflects this change in the direction of intervention.

\section{Banks' balance sheets continue to}

\section{strengthen, but high NPLs and exposure to} currency-induced credit risk remain as

vulnerabilities. Banks' reliance on wholesale

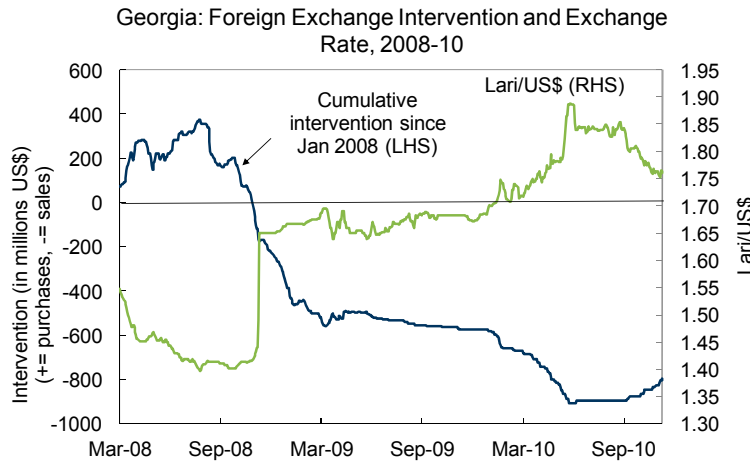

Georgia: Sources of Bank Funding, 2006-10 (In percent)

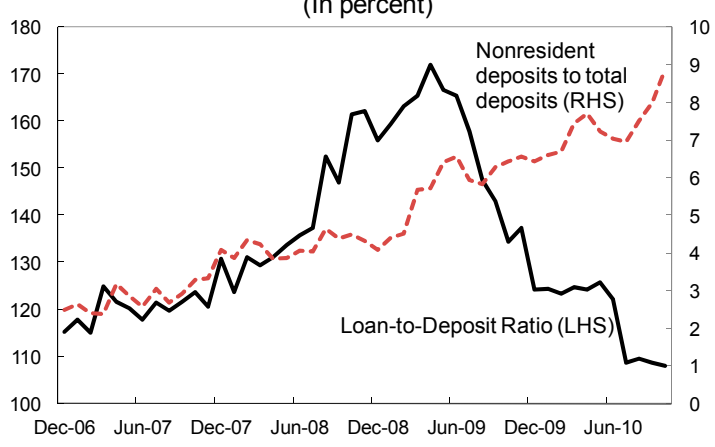

Sources: Georgian authorities; and Fund staff estimates. external funding has declined significantly since mid-2009, but the decline has been offset in part by increases of nonresident deposits, which now account for about 10 percent of total deposits. Although still high, NPLs have been declining since May owing to an improved environment, write-offs, and repossessed assets.

Georgia: Selected Monetary and Financial Soundness Indicators, 2008-10

\begin{tabular}{|c|c|c|c|c|c|c|c|c|c|c|c|c|}
\hline & \multicolumn{4}{|c|}{2008} & \multicolumn{4}{|c|}{2009} & \multicolumn{4}{|c|}{2010} \\
\hline & Mar. & Jun. & Sep. & Dec. & Mar. & Jun. & Sep. & Dec. & Mar. & Jun. & Sep. & Oct. \\
\hline Deposit dollarization (in percent) & 60.9 & 60.0 & 61.7 & 75.7 & 75.2 & 73.2 & 72.6 & 73.2 & 71.0 & 71.4 & 71.8 & 70.9 \\
\hline Loan-to-deposit ratio (in percent) & 129.4 & 135.7 & 147.0 & 155.9 & 165.3 & 165.4 & 143.0 & 124.2 & 124.7 & 122.2 & 108.7 & 108.0 \\
\hline Credit-to-GDP ratio (in percent) & 28.5 & 30.0 & 29.2 & 31.9 & 30.7 & 30.2 & 29.6 & 29.3 & 29.6 & 30.6 & 29.8 & 29.4 \\
\hline Capital adequacy ratio (in percent) $1 /$ & 17.5 & 15.7 & 17.0 & 13.9 & 15.2 & 17.6 & 20.2 & 19.1 & 18.3 & 17.4 & 18.2 & 18.5 \\
\hline Capital adequacy ratio (in percent) $2 /$ & & & & 24.0 & 23.6 & 27.1 & 27.4 & 25.6 & 24.6 & 23.3 & 24.4 & 24.7 \\
\hline Liquidity ratio (in percent) 3 / & 36.8 & 33.3 & 30.4 & 28.3 & 30.8 & 31.4 & 40.6 & 39.1 & 41.6 & 37.5 & 37.3 & 38.8 \\
\hline Nonperforming loans (in percent of total loans) 4/ & 3.0 & 3.4 & 9.9 & 12.8 & 15.2 & 18.8 & 18.2 & 17.9 & 17.1 & 16.3 & 15.1 & 14.9 \\
\hline Nonperforming loans (in percent of total loans) 5 / & & & & 4.1 & 5.4 & 7.1 & 8.3 & 6.3 & 6.6 & 6.9 & 7.8 & 6.8 \\
\hline Loans collateralized by real estate (in percent of total loans) & 43.6 & 40.5 & 41.6 & 43.6 & 46.4 & 48.0 & 49.1 & 55.5 & 55.5 & 54.1 & 52.3 & 52.6 \\
\hline Loans in foreign exchange (in percent of total loans) & 65.9 & 64.9 & 67.5 & 72.8 & 75.3 & 77.3 & 77.6 & 76.9 & 75.9 & 73.7 & 72.8 & 72.5 \\
\hline Specific provisions (in percent of total loans) & 1.9 & 2.2 & 4.7 & 6.0 & 7.5 & 9.4 & 10.2 & 9.7 & 9.4 & 8.9 & 8.3 & 8.1 \\
\hline Net foreign assets (in percent of total assets) & -17.2 & -20.2 & -21.6 & -19.6 & -22.5 & -24.4 & -18.4 & -14.9 & -15.1 & -12.4 & -6.2 & -6.3 \\
\hline Net open foreign exchange position (in percent of regulatory capital) & 3.5 & 1.5 & 1.5 & 1.7 & 9.1 & 8.8 & 10.4 & 1.8 & 4.3 & 5.3 & 3.3 & 2.7 \\
\hline Return on equity (cumulative through the year, annualized) $6 /$ & 10.2 & 8.9 & -2.9 & -12.6 & -7.6 & -8.4 & -7.3 & -4.3 & 4.0 & 4.8 & 8.0 & 9.1 \\
\hline
\end{tabular}

Sources: National Bank of Georgia; and Fund staff estimates.

1/ National definition. Risk weight to forex loans was reduced from 200 to 175 percent in September 2008, and to 150 percent in August 2009.

2/ Basel I definition.

3/ Ratio of liquid assets to 6-month and shorter maturity liabilities.

4/ National definition: NPLs are defined as loans in substandard, doubtful, and loss loan categories.

$5 /$ IMF definition.

6/ Pre tax. 


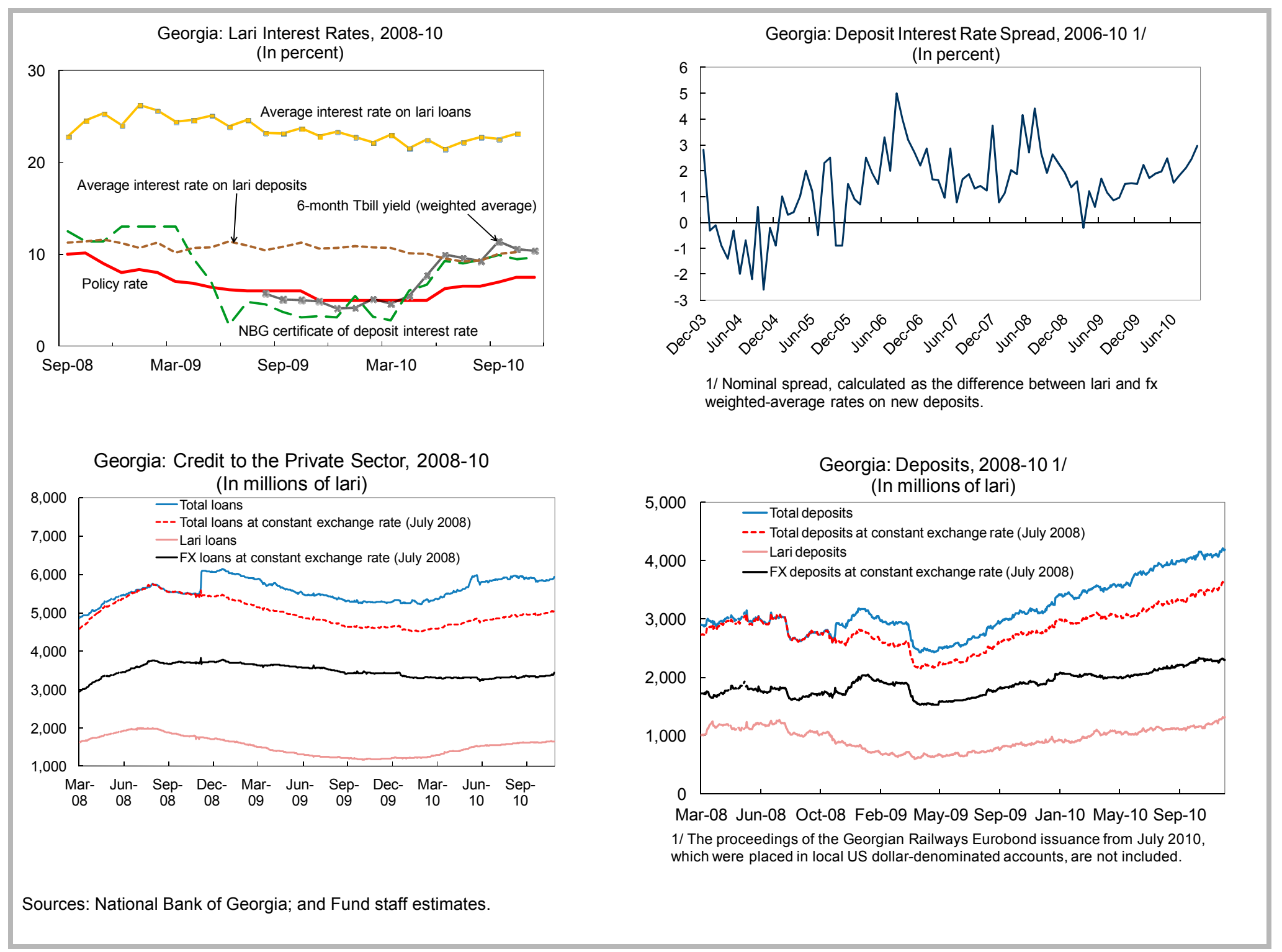

\section{CInternational Monetary Fund. Not for Redistribution}




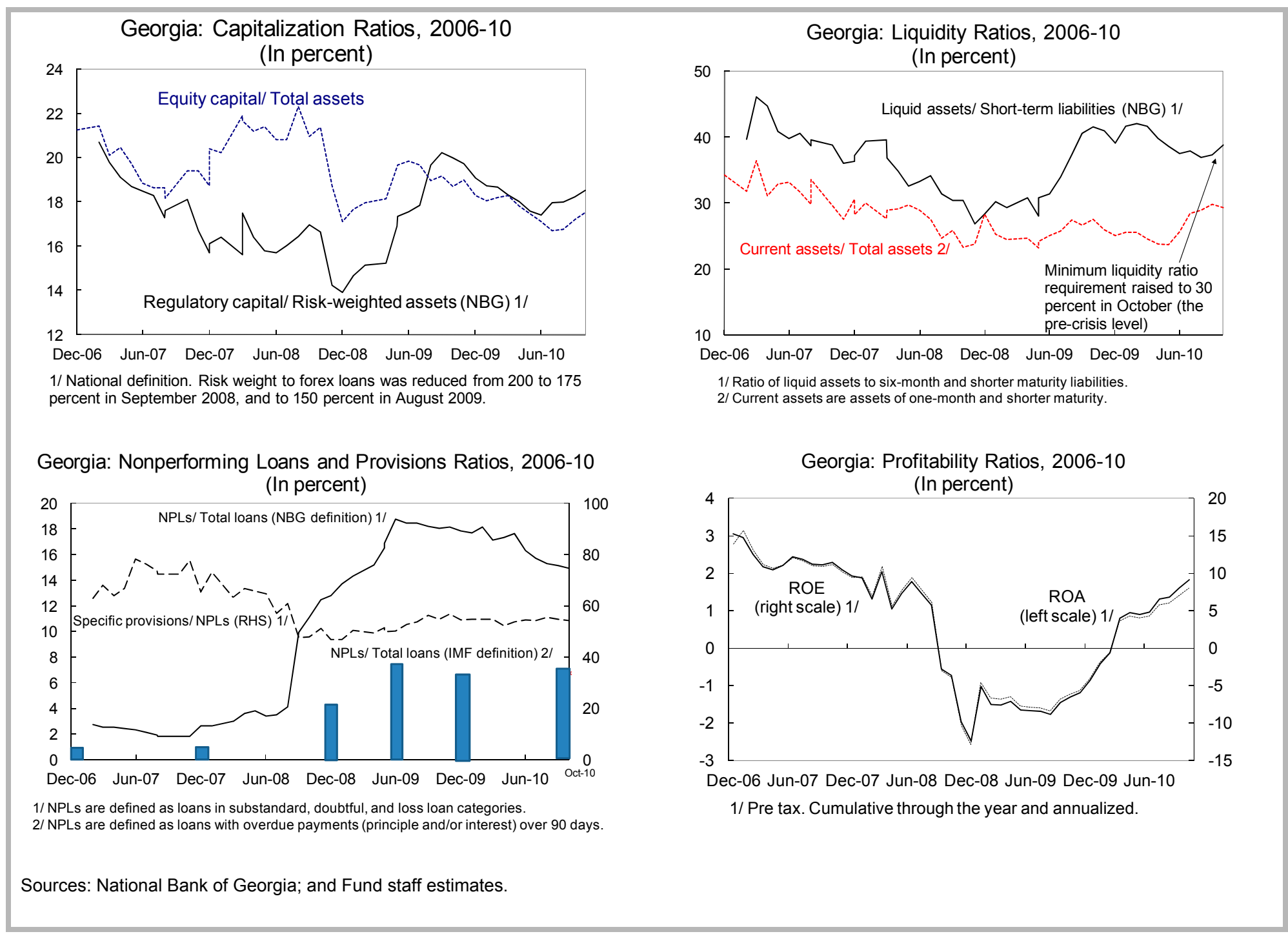

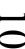




\section{Policies FOR 2011 AND The EXIT STRATEGY}

Based on the strength of the economic recovery, discussions focused on:

- The pace of fiscal adjustment;

- the stance of monetary policy, following its recent tightening;

- NIR buildup and exchange rate policy; and

- financial regulation in the post-crisis environment.

\section{A. Outlook for 2011}

10. Real GDP is projected to grow by 4.5 percent in 2011 , based on the expectation that private sector demand will strengthen as the fiscal stimulus is withdrawn. The transition from public to private-led growth is not yet firmly established, however, and the recovery of private investment in particular will depend on continued credit growth and private capital inflows, including FDI.

\section{Risks to short-term growth,} which were previously perceived to lie mostly on the downside, are now more evenly balanced around the central scenario. A failure of private capital inflows to pick up as projected, or inadequate credit growth, could still cause growth to falter. On the upside, growth could exceed 5 percent, particularly if fueled by stronger capital inflows.

\section{Inflation is projected to decline} (to around 6 percent) by end-2011, with risks mostly on the upside. The projected decline in inflation is based on monetary and fiscal policies remaining sufficiently restrained. The upside risk reflects the narrowing of the output gap and the possible emergence of capacity constraints. The projection is subject to considerable uncertainty given observed

Georgia: Current Account Balance and its Financing, 2006-15 (In percent of GDP)

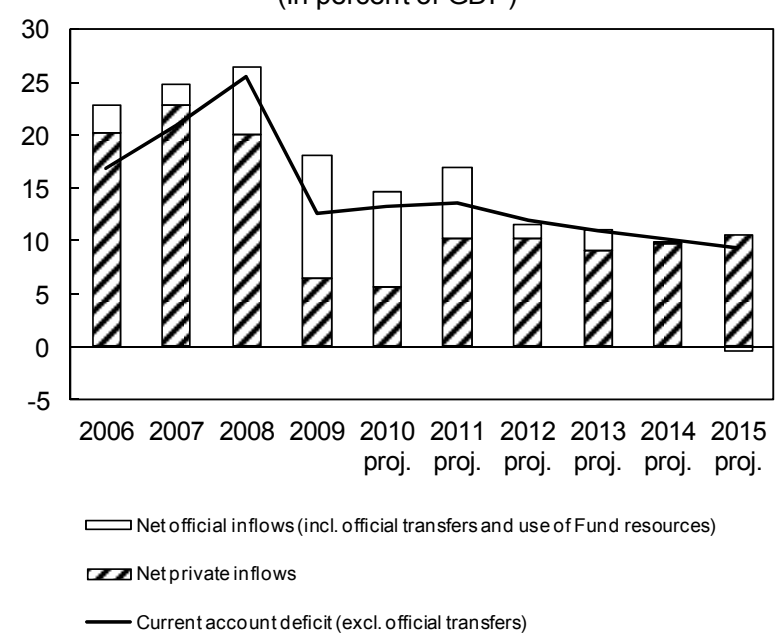

Georgia: Saving-Investment Balances, 2003-15

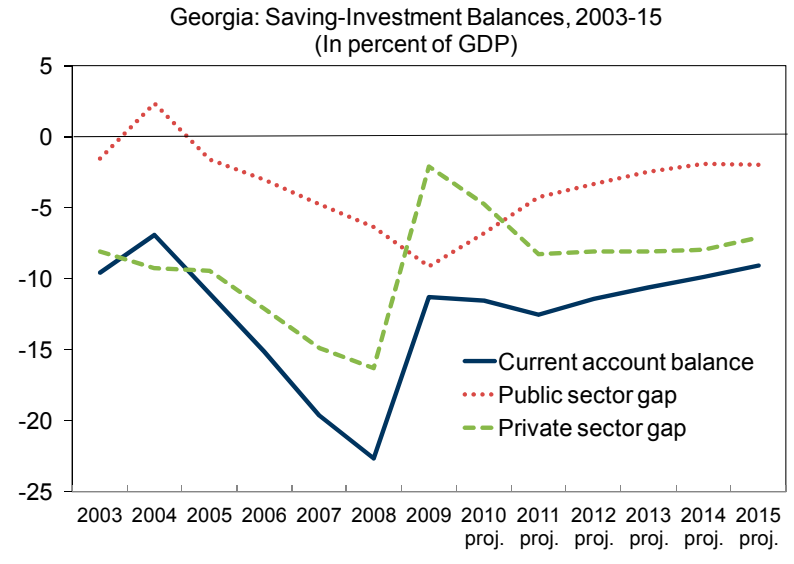

Source: Georgian authorities; and Fund staff estimates. 
volatility in inflation and the unknown impact of recent price hikes on expected inflation and wages.

13. The balance of payments is projected to improve in 2011 (from an overall deficit of $\$ 113$ million in 2010 to an overall surplus of \$213 million), owing essentially to the expected recovery of private capital inflows, which also remains the main risk factor. The current account deficit (in percent of GDP) is projected to widen temporarily owing to a worsening transfer and income balance, but would still be lower than expected at the time of the Sixth Review. On current trends, the deficit should decline steadily over the medium term, reflecting parallel improvements in the fiscal balance and in the private savinginvestment balance.

\section{B. Fiscal Policy}

14. Riding on higher-thanexpected economic growth, the authorities target a lower 2011 fiscal deficit (4.3 percent of GDP) than projected at the time of the Sixth Review. However, the structural adjustment from 2009 to 2011 would be somewhat lower, owing to tax revenue shortfalls. Still, two-thirds of the structural adjustment envisioned from 2009 to 2013 will be achieved in the first two years of the consolidation period.

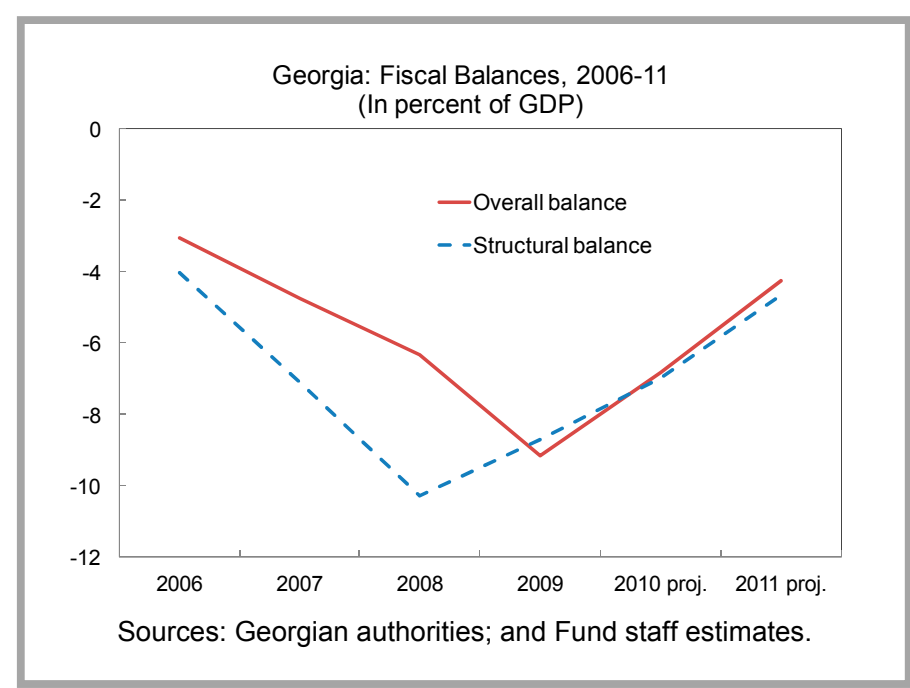

Georgia: Overall and Structural Deficits, 2009-11

(In percent of GDP)

\begin{tabular}{lccccc}
\hline & 2009 & & 2010 & \multicolumn{2}{c}{2011} \\
\cline { 2 - 6 } & & 6th Rev. & Proj. & 6th Rev. & Proj. \\
\hline \multirow{2}{*}{ Overall deficit } & -9.2 & -6.3 & -6.8 & -4.8 & -4.3 \\
Structural deficit 1/ & -8.7 & -6.1 & -7.0 & -4.4 & -4.7 \\
\hline
\end{tabular}

Sources: Ministry of Finance; and Fund staff estimates.

1/ Based on identical potential GDPs for the sixth and seventh reviews.

15. Adjustment in $\mathbf{2 0 1 1}$ is based essentially on expenditure containment. The authorities are committed to capping expenditure in order to allocate possible gains on the revenue front toward deficit reduction. Staff discussed with the authorities various revenue and expenditure measures consistent with the envisaged fiscal consolidation. The authorities consider that focusing their consolidation efforts on curbing current spending is more 
growth-enhancing and thereby ultimately more favorable to improving social conditions. Expenditure containment will reduce social spending in real terms, but the authorities argued that the impact was mitigated by the economic recovery and that social coverage of the most vulnerable was already quite extensive and has been improved through efficiency gains in the health insurance sector. The revenue measures that were supposed to be introduced in 2010 were taken as expected. However, the tax-to-GDP ratio
Georgia: Government Revenues and Expenditures, 2003-15

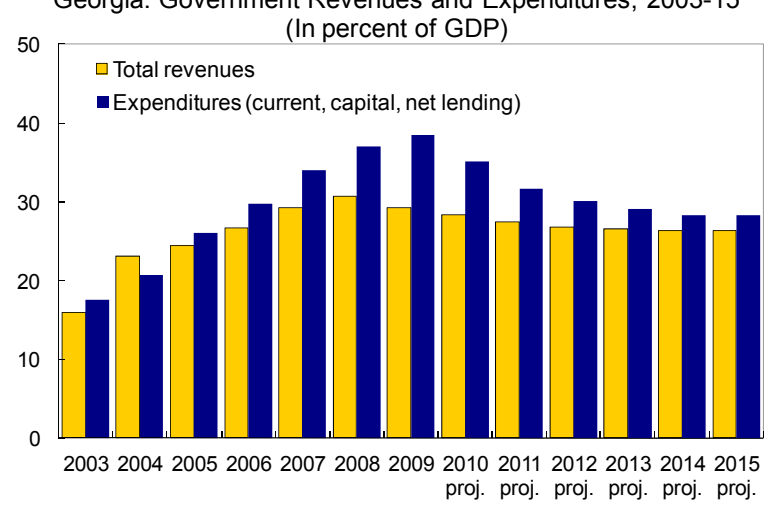

Sources: Georgian authorities; and Fund staff estimates.

(for both 2010 and 2011) is lower than anticipated at the time of the Sixth Review. In large part, this reflects a lower yield of all taxes (including new ones), ${ }^{1}$ one-off factors, but also the withdrawal of the VAT measures on private health and private education that were to be introduced in 2011 - VAT on public health services will, however, come into effect in 2011.

Georgia: 2011 Budget

\begin{tabular}{ccc}
\hline Change & Comments \\
$2010-11$ & \\
\hline
\end{tabular}

(In percent of GDP)

\begin{tabular}{|c|c|c|}
\hline Increase in revenues & -0.9 & \\
\hline Tax revenues & 0.5 & $\begin{array}{l}\text { New excises on beer, spirit, telecommunications (From August and September 2010), } \\
\text { harmonization of personal income tax rates, VAT on public healthcare (2011) }\end{array}$ \\
\hline Other revenues & -0.2 & Loss of railway company dividends, no adjustment in penalties and fees \\
\hline Grants & -1.2 & Decrease in project grants (termination of USAID Millennium Challenge Corporation) \\
\hline Decrease in expenditures & 3.5 & \\
\hline Current spending & 2.3 & \\
\hline Compensation for employees & 0.4 & No new hiring, no indexation of public wages to inflation \\
\hline Use of goods and services & 0.8 & Reduction of ministry of defense budget by $11 \%$ \\
\hline Subsidies & 0.2 & No nominal increase in services provided by local governments \\
\hline Social expenses & 0.8 & No pension increase, no change in thresholds of social assistance schemes \\
\hline Other expenses & 0.3 & Education spending stable in nominal terms \\
\hline Interest & -0.2 & Higher cost of external debt \\
\hline Capital spending & 1.1 & \\
\hline Domestically financed & 0.6 & Less domestically-financed capital projects \\
\hline Externally financed & 0.5 & \\
\hline Net lending & 0.1 & $\begin{array}{l}\text { Lower onlending (reflecting lower disbursements by KFW, EBRD, and EIB to finance electricity } \\
\text { project) }\end{array}$ \\
\hline Reduction in fiscal deficit & 2.5 & \\
\hline
\end{tabular}

Sources: Ministry of Finance; and Fund staff estimates.

\footnotetext{
${ }^{1}$ Lower-than-anticipated tax yields reflect mainly low personal income tax receipts resulting from the lagged response of wages to higher GDP, and lower-than-expected proceeds from the new telecommunication turnover tax, owing to a one-month implementation delay and the lowering of the tax base as private operators cut telecommunication prices.
} 
In light of the already significant adjustment being targeted, the authorities considered that taking additional compensatory revenue measures would threaten the recovery. They also stressed that the tax-to-GDP ratio, corrected for one-offs, ${ }^{2}$ is still expected to increase by 0.3 percent in 2010 and 0.5 percent in 2011 .

16. The medium-term fiscal framework adopted by the government in July 2010 targets a reduction of the deficit to $2-\mathbf{3}$ percent of GDP by 2013. The debt-to-GDP ratio is expected to peak at 43.6 percent of GDP in 2011, declining to 35.9 percent of GDP by 2015 . The mission questioned the sustainability of expenditure containment over the medium term, noting in particular that the spending cuts implemented in 2010 and envisaged in 2011 entail a significant real revenue reduction for public wageearners and social system beneficiaries. The authorities deemed that, if pressures to reverse these cuts were to emerge, there would be sufficient room to decrease the capital budget further. The World Bank has begun exploring ways in which social spending, half of which is accounted for by pensions, could be better targeted to enhance the effectiveness of social safety nets through the consolidation process. The
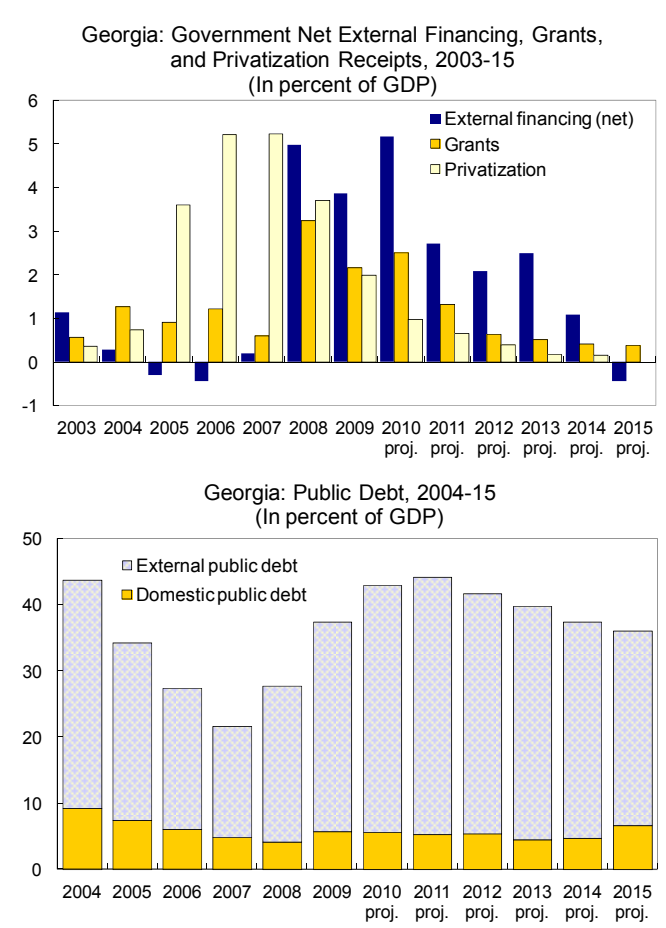

Sources: Georgian authorities; and Fund staff estimates. constitutional amendment requiring that tax increases be subject to referendums was adopted on December 15, 2010. Recognizing the need to preserve adequate policy flexibility in the event of adverse economic developments, the authorities have introduced an escape clause in the referendum requirement. The specific circumstances under which the referendum requirement would be suspended will be specified separately in the Economic Freedom Act, which will also set deficit and debt limits.

\footnotetext{
${ }^{2}$ In particular, 2009 taxes are inflated by the arrears clearance paid by a line ministry, equivalent to 0.9 percent of GDP.
} 
Georgia: Social Expenditures (General Government), 2008-11

\begin{tabular}{lcccc}
\hline & 2008 & 2009 & 2010 & 2011 \\
\hline & \multicolumn{4}{c}{ (In percent of GDP) } \\
Health programs & 1.2 & 1.6 & 1.7 & 1.5 \\
Pensions & 4.0 & 4.7 & 4.3 & 3.9 \\
Social assistance 1/ & 1.1 & 1.4 & 1.2 & 1.1 \\
Other & 0.9 & 0.7 & 0.7 & 0.6 \\
Total & 7.2 & 8.4 & 7.9 & 7.1 \\
\hline
\end{tabular}

Sources: Ministry of Finance; and Fund staff estimates.

$1 /$ Includes assistance to internally displaced persons (IDPs).

17. The authorities plan to move to program budgeting by 2012. Next steps include conducting training for the ministry of finance and pilot ministries and designing measurable indicators.

\section{Monetary and Exchange Rate Policy}

18. Monetary policy in 2011 will be guided by three objectives:

- $\quad$ Supporting gradual disinflation back toward 6 percent by end-2011;

- $\quad$ increasing the level of NIR to reinforce the exit strategy; and

- $\quad$ raising the credibility of the local currency to promote dedollarization.

19. Calibrating monetary policy in pursuit of these objectives is difficult owing to weaknesses in the transmission mechanism, stemming from:

- $\quad$ The high degree of dollarization, and the limited leverage the authorities have over the on-shore dollar interest rate. The authorities are concerned that an excessive increase in local currency interest rates would cause banks to shift to cheaper dollar lending, sourced from abroad.

- $\quad$ The uncertain transmission of policy interest rate changes. The policy rate is expected to regain traction on market rates (including longer-term rates) following the normalization of liquidity and credit conditions, and the April reforms of the central bank refinancing window and standing facilities. Evidence of that can be seen in the parallel movements of the policy rate and the lari deposit rate in the last few months. The extension of the yield curve should also facilitate stronger transmission of policy rates to lending rates.

- $\quad$ Uncertainty about the inflation process and the impact of monetary policy on economic activity. With technical assistance from the Fund, the National Bank of Georgia (NBG) is building up its modeling capacity with a view to better inform policy decisions. 


\section{Subject to these constraints, the authorities stand ready to tighten monetary} policy further to meet their objectives. They indicated that they are considering complementing the recent increase in the policy rate, which contributed to a significant increase in $\mathrm{CD}$ and T-bill rates, with an increase in reserve requirements on foreign exchange deposits. Prudential measures recently adopted and planned (see next section) are also effectively tightening the monetary stance. The NBG's current inflation forecast model suggests that the monetary program is consistent with the projected disinflation. Monetary policy decisions will continue to be informed by changes in projected inflation, and developments in monetary aggregates and the exchange rate. The authorities will in particular monitor closely price developments to avoid the emergence of second round effects.

21. The 2011 monetary program's credit and deposit growth projections are in line with projected economic growth and resumption of financial deepening. The authorities and staff agreed that credit growth in the 15-20 percent range, which would raise the creditto-GDP ratio to the pre-crisis level of 30 percent, would not be inflationary.

22. Consistent with the exit strategy, the authorities are targeting an increase in NIR in 2011. This increase would begin to reverse the decline observed since 2007, which financed part of the balance of payments gap opened by the war and subsequent financial crisis.

\section{Financial Sector Policies}

\section{Stability concerns have abated, and the authorities are in the process of} adjusting the regulatory framework following the normalization of credit market conditions. The central bank has raised the liquidity ratio back to 30 percent (pre-crisis level) from 20 percent, effective October 1. It is also considering raising the risk weights on foreign exchange loans to unhedged borrowers, which were lowered in the wake of the crisis. ${ }^{3}$ Some bankers consider that the combination of monetary and regulatory tightening is premature and could thwart the desired growth in credit, but the NBG projects that the recapitalization needs created by an increase in the capital risk weight of foreign exchange loans would be limited. ${ }^{4}$ The relatively large intermediation margins of the Georgian banking sector reflect, in part, the cost of carrying high capital and liquidity buffers. To address this problem, the

\footnotetext{
${ }^{3}$ The risk weight to foreign exchange loans was reduced from 200 to 175 percent in September 2008, and to 150 percent in August 2009.

${ }^{4}$ If the risk weights on foreign exchange loans are raised to 175 from 150 percent, recapitalization needs stemming from satisfying the CAR requirement, assuming a 15 percent credit growth and a constant credit dollarization ratio, would amount to GEL 15 million (about $\$ 8$ million), i.e., an increase in regulatory capital of less than 1 percent. The increase would be even less if taking into account potential capital increases from retained profits going forward.
} 
authorities are preparing for a gradual move to differentiated risk-based prudential requirements, which would make supervision more efficient and less costly.

24. The authorities are considering alternative schemes for distressed asset management (DAM), but lack of demand and urgency from banks to sell assets at depressed prices are major impediments. The authorities consider that specialized firms would manage distressed assets more efficiently than banks, and are evaluating, jointly with IFIs, alternative DAM schemes and regulatory changes. Apart from the lack of interest from banks, however, this initiative is constrained by limited domestic capacity to absorb these assets, and limited interest from foreign investors owing to the small size of the distressed assets pool.

\section{E. The Exit Strategy and Risks}

25. Balance of payments risks remain elevated over the medium term. The program was built on the expectation that a steady recovery of private capital inflows (mainly FDI) would enable Georgia to return to a path of privately financed high economic growth, and that, as of 2012, external financing needs would be covered entirely by private sector inflows and regular official financing. While the improvement in the overall balance of payments since June 2010 is consistent with this scenario, there are risks that balance of payments gaps could reemerge, in which case the adjustment process may have to be prolonged. Such an outcome could be triggered by:

- $\quad$ A failure of FDI to rebound as projected. The strength of the balance of payments since the summer would be consistent with increased private capital inflows. However, these flows have proven to be volatile. A shortfall in FDI would not only open a balance of payments gap, but could also adversely affect GDP growth and widen the fiscal deficit, as illustrated in the downside scenario (Box 1).

- $\quad$ An inadequate supply response to the recovery of demand growth. The resulting overheating and loss of competitiveness would create new external imbalances down the road. 


\section{Box 1. Georgia: Alternative Scenario with Lower FDI}

The scenario illustrates the risks associated with a failure of FDI to rebound as projected. The alternative scenario assumes a stabilization of FDI at 5 percent of GDP, slightly below the 2010 level. Assuming an unchanged productivity of capital, but a loss of export competitiveness, real GDP growth would decline to about $3 \frac{1}{2}$ percent on average over the next 5 years. The current account deficit would narrow quite sizably, but the balance of payments would deteriorate (relative to the baseline scenario) by the equivalent of 0.9 percent of GDP on average over the period 2011-15, and to 1.1 percent of GDP in 2015; the associated loss of international reserves would come to US\$625 million by 2015 .

An imbalance would also appear in the fiscal accounts. Based on the same fiscal policy of the baseline scenario (same level of real expenditure and same tax-to-GDP ratio), the deficit would begin to rise again and reach 3.8 percent of GDP by 2015. The primary fiscal balance would exceed the debt-stabilizing level by 1.1 percentage point of GDP.

\begin{tabular}{|c|c|c|c|c|}
\hline \multicolumn{5}{|c|}{ Georgia: Alternative Medium-Term Scenarios (2011-15) } \\
\hline & \multicolumn{2}{|c|}{ 2011-15 average } & \multicolumn{2}{|c|}{2015} \\
\hline & central & low case & central & low case \\
\hline Real GDP growth & 4.9 & 3.6 & 5.0 & 3.3 \\
\hline Investment rate (in percent of GDP) & 19.8 & 19.3 & 21.3 & 21.3 \\
\hline \multicolumn{5}{|l|}{ General government (in percent of GDP) } \\
\hline Revenues & 26.7 & 26.7 & 26.3 & 26.4 \\
\hline Tax revenue & 24.2 & 24.2 & 24.2 & 24.2 \\
\hline Current expenditure & 22.8 & 23.7 & 22.2 & 23.7 \\
\hline Capital expenditure & 6.6 & 6.8 & 6.1 & 6.4 \\
\hline Balance & -2.8 & -3.8 & -2.0 & -3.8 \\
\hline Total Public Debt & 39.6 & 42.8 & 35.9 & 42.7 \\
\hline \multicolumn{5}{|l|}{ Investment and saving (in percent of GDP) } \\
\hline Investment $1 /$ & 19.8 & 19.3 & 21.3 & 21.3 \\
\hline Public & 6.0 & 6.2 & 6.0 & 6.2 \\
\hline Private & 13.8 & 13.2 & 15.3 & 15.1 \\
\hline Gross national saving & 9.1 & 10.1 & 12.2 & 13.9 \\
\hline Public & 3.8 & 3.0 & 4.1 & 2.6 \\
\hline Private & 5.2 & 7.0 & 8.1 & 11.2 \\
\hline Saving-investment balance $=$ current account balance & -10.7 & -9.3 & -9.1 & -7.4 \\
\hline \multicolumn{5}{|l|}{ External sector } \\
\hline Exports of goods and services (percent of GDP) & 34.1 & 33.9 & 34.7 & 33.7 \\
\hline volume, percentage change & 7.8 & 5.9 & 7.3 & 3.9 \\
\hline percent change in volume/percent real GDP growth 2/ & 1.6 & 1.6 & $\ldots$ & $\ldots$ \\
\hline Imports of goods and services (percent of GDP) & 49.9 & 33.9 & 48.4 & 33.7 \\
\hline volume, percentage change & 5.7 & 3.4 & 5.7 & 3.4 \\
\hline percent change in volume/ percent real GDP growth $2 /$ & 1.2 & 1.0 & $\ldots$ & $\ldots$ \\
\hline Gross international reserves (in millions of US $\$$ ) & 2,547 & 2,195 & 2,566 & 1,940 \\
\hline Gross international reserves (in percent of total external debt) & 29 & 25 & 28 & 21 \\
\hline Foreign direct investment (percent of GDP) & 7.4 & 5.0 & 7.8 & 5.0 \\
\hline
\end{tabular}



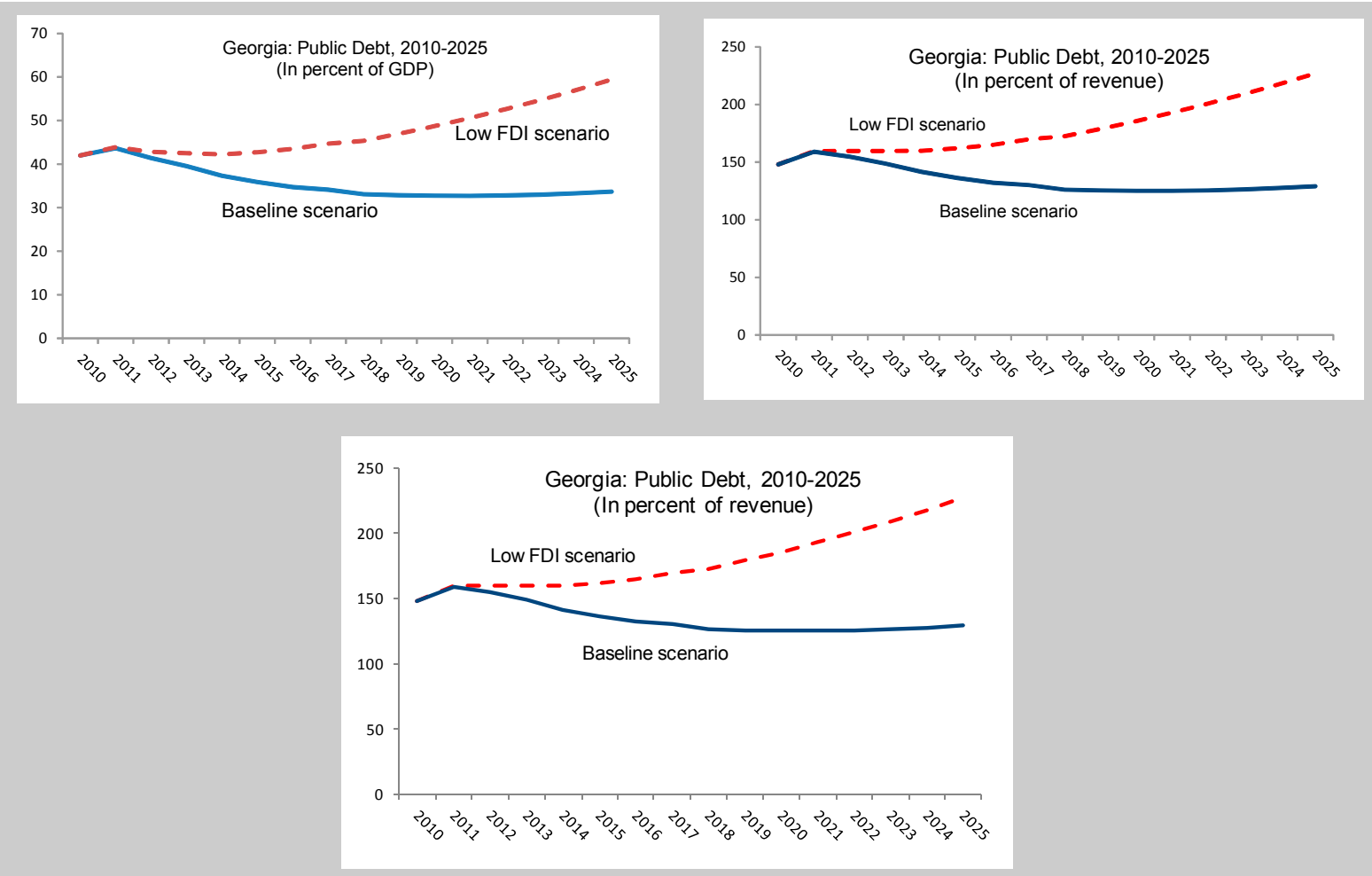

Sources: Georgian authorities; and Fund staff estimates and projections.

- Debt rollover. The Debt

Sustainability Analysis (DSA) points to low solvency risks, but high rollover risks in 2013 linked to high Fund and Eurobond repayment obligations. Recent rating upgrades should facilitate market rollover, but the amounts involved still pose risks. Although the resilience of the Georgian sovereign bond yield to the recent turbulence in the European markets is encouraging, contagion risks remain.

\section{To mitigate these risks, the}

authorities have expressed interest in a successor Fund arrangement. Discussions could begin in April, based on the conclusions of the Article IV consultation (scheduled for March) and the Ex-Post Assessment Update (under preparation).

\section{Meanwhile, the authorities stand ready to tighten policies should foreign} exchange depreciation pressures reemerge, beyond seasonal factors. While continuing to 
rely on exchange rate adjustment, the authorities also indicated that they could aim for a lower fiscal deficit.

\section{Program Issues}

28. Rephasing of purchases by combining the final two purchases into one purchase upon completion of the Ninth and final Review is requested owing to the delay in completing the Seventh and Eighth Reviews. The delay stems from the additional time needed to assess exchange rate developments in November-December prior to setting NIR targets for 2011. The rephasing would combine the last two purchases under the program into a single purchase of SDR 70 million, which would become available upon completion of the last review scheduled for early June.

\section{Staff Appraisal}

29. Policies are on track and have broadly delivered on program objectives. The economic recovery appears to be on a relatively solid footing, substantial progress has been made toward reestablishing fiscal sustainability, and banking sector indicators have improved markedly. However, net international reserves are still relatively low, which, together with remaining external risks, creates vulnerabilities for the exit strategy.

30. Fiscal adjustment is largely in line with program objectives, but could have been accelerated in $\mathbf{2 0 1 1}$ in view of the favorable cyclical conditions and remaining risks. The commitment to cap expenditure in 2011 is welcome and provides reassurances that fiscal policy will be countercyclical, and that the deficit would decline further under an upside growth scenario. Faster fiscal adjustment in 2011, ahead of two election years, could have strengthened the exit strategy against external risks without undermining the recovery. Over the medium term, the relatively high share of capital spending in total government spending creates room for additional expenditure compression. However, revenue measures should also be considered if necessary to achieve the medium-term deficit objectives. In this regard, the introduction of an escape clause in the constitutional amendment subjecting tax increases to a referendum is welcome as it increases policy flexibility.

\section{While a pause in monetary tightening through the policy rate is appropriate at} this juncture, the authorities should remain ready to tighten monetary policy should inflationary pressures persist. The gap between the policy rate and the deposit rate has narrowed significantly. This should contribute to strengthen the traction of monetary policy going forward, as evidenced by the recent increase in local currency deposit rates in response to the earlier hikes in the policy rate. Given the uncertain lags in the transmission mechanism of monetary policy, further rate increases should be conditioned on evidence that inflation is not abating as expected. At the same time, reserve requirements on dollar deposits and foreign loans should be increased to complement the increase in domestic interest rates. 
32. Exchange rate flexibility should remain an essential instrument of adjustment in the event of less favorable external developments; moreover, the need to rebuild international reserves will limit considerably the room for intervention. The program's international reserve target for 2011 also calls for more aggressive purchases of foreign exchange in the market, as those recently conducted by the NBG, when opportunities present themselves. Looking ahead, and consistent with preserving exchange rate flexibility, foreign exchange purchases could be undertaken on a pre-established calendar.

33. An adjustment in financial regulations, which were loosened during the crisis, is warranted. Given the impact of higher capital buffers on intermediation margins, ongoing capacity building toward risk-based supervision is welcome, as it will increase the efficiency of the banking system.

34. In light of the authorities' commitment to reduce the 2011 fiscal deficit by more than envisaged at the time of the Sixth Review, staff supports the authorities' requests for completing the Seventh and Eighth Reviews, for waivers of nonobservance of performance criteria, the establishment of end-March 2011 PCs, and rephasing of purchases as specified in the LOI ( $₫ 29)$. 
Table 1. Georgia: Selected Macroeconomic Indicators, 2008-15

\begin{tabular}{|c|c|c|c|c|c|c|c|c|}
\hline & $\begin{array}{r}2008 \\
\text { Act. }\end{array}$ & $\begin{array}{r}2009 \\
\text { Prel. }\end{array}$ & $\begin{array}{r}2010 \\
\text { Proj. }\end{array}$ & $\begin{array}{r}2011 \\
\text { Proj. }\end{array}$ & $\begin{array}{r}2012 \\
\text { Proj. }\end{array}$ & $\begin{array}{r}2013 \\
\text { Proj. }\end{array}$ & $\begin{array}{r}2014 \\
\text { Proj. }\end{array}$ & $\begin{array}{r}2015 \\
\text { Proj. }\end{array}$ \\
\hline & \multicolumn{8}{|c|}{ (Annual percentage change, unless otherwise indicated) } \\
\hline \multicolumn{9}{|l|}{ National accounts } \\
\hline Nominal GDP (in million lari) & 19,075 & 17,986 & 20,490 & 23,018 & 25,619 & 28,514 & 31,737 & 35,323 \\
\hline Real GDP growth & 2.3 & -3.8 & 6.3 & 4.5 & 5.0 & 5.0 & 5.0 & 5.0 \\
\hline Population (in million) 1/ & 4.4 & 4.4 & 4.4 & 4.4 & 4.4 & 4.4 & 4.4 & 4.4 \\
\hline GDP deflator, period average & 9.7 & -2.0 & 7.2 & 7.5 & 6.0 & 6.0 & 6.0 & 6.0 \\
\hline Consumer price index, period average & 10.0 & 1.7 & 7.0 & 8.8 & 6.0 & 6.0 & 6.0 & 6.0 \\
\hline Consumer price index, end-of-period & 5.5 & 3.0 & 10.5 & 6.0 & 6.0 & 6.0 & 6.0 & 6.0 \\
\hline GDP per capita (in US\$) & 2,937 & 2,455 & 2,618 & 2,880 & 3,089 & 3,338 & 3,607 & 3,898 \\
\hline \multirow[t]{2}{*}{ Unemployment rate (in percent) } & 16.5 & 16.9 & $\ldots$ & $\ldots$ & $\ldots$ & $\ldots$ & $\ldots$ & $\ldots$ \\
\hline & \multicolumn{8}{|c|}{ (In percent of GDP) } \\
\hline \multicolumn{9}{|l|}{ Investment and saving } \\
\hline Investment 2/ & 21.5 & 14.4 & 15.0 & 17.2 & 18.9 & 20.3 & 21.2 & 21.3 \\
\hline Public & 4.3 & 6.9 & 7.2 & 6.4 & 6.1 & 5.8 & 5.8 & 6.0 \\
\hline Private & 17.2 & 7.6 & 7.8 & 10.8 & 12.8 & 14.5 & 15.4 & 15.3 \\
\hline Gross national saving & -1.2 & 3.1 & 3.4 & 4.6 & 7.5 & 9.7 & 11.3 & 12.2 \\
\hline Public & 2.2 & -0.8 & 1.9 & 3.3 & 3.6 & 4.0 & 4.2 & 4.1 \\
\hline Private & -3.4 & 3.9 & 1.5 & 1.3 & 3.9 & 5.7 & 7.1 & 8.1 \\
\hline Saving-investment balance & -22.7 & -11.3 & -11.6 & -12.6 & -11.4 & -10.6 & -9.9 & -9.1 \\
\hline \multicolumn{9}{|l|}{ Consolidated government operations } \\
\hline Total government debt & 25.0 & 37.0 & 42.0 & 43.6 & 41.4 & 39.5 & 37.3 & 35.9 \\
\hline Of which : foreign-currency denominated & 20.9 & 31.4 & 36.4 & 38.4 & 36.1 & 35.1 & 32.7 & 29.3 \\
\hline Revenue $3 /$ & 30.7 & 29.3 & 28.4 & 27.4 & 26.8 & 26.6 & 26.4 & 26.3 \\
\hline Expenses & 28.5 & 30.1 & 26.4 & 24.1 & 23.2 & 22.6 & 22.2 & 22.2 \\
\hline Operating balance & 2.2 & -0.8 & 1.9 & 3.3 & 3.6 & 4.0 & 4.2 & 4.1 \\
\hline Capital spending and net lending & 8.6 & 8.4 & 8.8 & 7.6 & 6.9 & 6.5 & 6.1 & 6.1 \\
\hline Overall balance & -6.3 & -9.2 & -6.8 & -4.3 & -3.3 & -2.5 & -1.9 & -2.0 \\
\hline Statistical discrepancy & 0.0 & 0.0 & 0.0 & 0.0 & 0.0 & 0.0 & 0.0 & 0.0 \\
\hline Total financing & 6.3 & 9.2 & 6.8 & 4.3 & 3.3 & 2.5 & 1.9 & 2.0 \\
\hline Domestic & -2.3 & 3.3 & 0.2 & 0.9 & 0.8 & -0.2 & 0.7 & 2.4 \\
\hline External & 5.0 & 3.9 & 5.6 & 2.7 & 2.1 & 2.5 & 1.1 & -0.4 \\
\hline Privatization receipts & 3.7 & 2.0 & 1.0 & 0.7 & 0.4 & 0.2 & 0.2 & 0.0 \\
\hline & \multicolumn{8}{|c|}{ (Annual percentage change, unless otherwise indicated) } \\
\hline \multicolumn{9}{|l|}{ Monetary sector } \\
\hline Reserve money & -4.5 & 21.8 & 5.9 & 6.1 & $\ldots$ & $\ldots$ & $\ldots$ & $\ldots$ \\
\hline Broad money (including fx deposits) 4/ & 7.0 & 8.1 & 22.0 & 20.0 & $\ldots$ & $\ldots$ & $\ldots$ & $\ldots$ \\
\hline Bank credit to the private sector & 28.2 & -13.5 & 12.9 & 16.4 & $\ldots$ & $\ldots$ & $\ldots$ & $\ldots$ \\
\hline Deposit interest rate (annual weighted average on flows) & 9.5 & 9.8 & $\ldots$ & $\ldots$ & $\ldots$ & $\ldots$ & $\ldots$ & $\ldots$ \\
\hline Lending interest rate (annual weighted average on flows) & 21.9 & 22.4 & $\ldots$ & $\ldots$ & $\ldots$ & $\ldots$ & $\ldots$ & $\ldots$ \\
\hline \multicolumn{9}{|l|}{ External sector } \\
\hline Exports of goods and services (percent of GDP) & 28.7 & 29.7 & 33.0 & 33.4 & 33.8 & 34.2 & 34.4 & 34.7 \\
\hline Annual percentage change & 15.9 & -13.2 & 18.5 & 11.5 & 8.5 & 9.2 & 8.9 & 9.1 \\
\hline Imports of goods and services (percent of GDP) & 58.3 & 48.9 & 52.4 & 52.0 & 50.6 & 49.4 & 48.9 & 48.4 \\
\hline Annual percentage change & 26.7 & -29.8 & 14.3 & 9.2 & 4.5 & 5.6 & 7.0 & 7.0 \\
\hline Net imports of oil (in US\$) & 762 & 555 & 631 & 679 & 742 & 802 & 847 & 892 \\
\hline Current account balance (in millions of US\$) & $-2,915$ & $-1,216$ & $-1,329$ & $-1,587$ & $-1,551$ & $-1,556$ & $-1,566$ & $-1,559$ \\
\hline In percent of GDP & -22.7 & -11.3 & -11.6 & -12.6 & -11.4 & -10.6 & -9.9 & -9.1 \\
\hline Gross international reserves (in millions of US\$) & 1,480 & 2,111 & 2,202 & 2,615 & 2,545 & 2,545 & 2,465 & 2,566 \\
\hline In months of next year's imports of goods and services & 3.4 & 4.2 & 4.0 & 4.6 & 4.2 & 3.9 & 3.6 & 3.5 \\
\hline Foreign direct investment (percent of GDP) & 12.2 & 6.1 & 5.2 & 6.6 & 7.1 & 7.5 & 7.8 & 7.8 \\
\hline Average exchange rate (lari per US\$) & 1.48 & 1.67 & $\ldots$ & $\ldots$ & $\ldots$ & $\ldots$ & $\ldots$ & $\ldots$ \\
\hline
\end{tabular}

Sources: Georgian authorities; and Fund staff estimates.

1/ Excludes Abkhazia residents.

$2 /$ Investment is measured on a net basis (acquisitions minus disposals of nonfinancial assets).

$3 /$ Includes grants.

4/ The proceeds of the Georgian Railway eurobond issuance from July 2010, which were deposited in accounts with Georgian commercial banks that placed them abroad are not included in broad money. 
Table 2. Georgia: Annual General Government Operations, 2009-15 1/

\begin{tabular}{|c|c|c|c|c|c|c|c|c|c|c|c|c|c|c|c|c|c|c|}
\hline & \multirow{2}{*}{2009} & \multicolumn{2}{|c|}{2010} & \multicolumn{2}{|c|}{2011} & \multirow{2}{*}{$\begin{array}{l}2012 \\
\text { Proj. }\end{array}$} & \multirow{2}{*}{$\begin{array}{l}2013 \\
\text { Proj. }\end{array}$} & \multirow{2}{*}{$\begin{array}{l}2014 \\
\text { Proj. }\end{array}$} & \multirow{2}{*}{$\begin{array}{l}2015 \\
\text { Proj. }\end{array}$} & \multirow{2}{*}{2009} & \multicolumn{2}{|c|}{2010} & \multicolumn{2}{|c|}{2011} & \multirow{2}{*}{$\begin{array}{l}2012 \\
\text { Proj. }\end{array}$} & \multirow{2}{*}{$\begin{array}{l}2013 \\
\text { Proj. }\end{array}$} & \multirow{2}{*}{$\begin{array}{l}2014 \\
\text { Proj. }\end{array}$} & \multirow{2}{*}{$\begin{array}{l}2015 \\
\text { Proj. }\end{array}$} \\
\hline & & 6 Rev. & Proj. & 6 Rev. & Proj. & & & & & & 6 Rev. & Proj. & 6 Rev. & Proj. & & & & \\
\hline & \multicolumn{9}{|c|}{ (In millions of lari) } & \multicolumn{9}{|c|}{ (In percent of GDP) } \\
\hline Revenues & 5,264 & 5,865 & 5,809 & 6,238 & 6,315 & 6,861 & 7,575 & 8,367 & 9,299 & 29.3 & 29.8 & 28.4 & 29.1 & 27.4 & 26.8 & 26.6 & 26.4 & 26.3 \\
\hline Taxes & 4,389 & 4,859 & 4,860 & 5,500 & 5,571 & 6,201 & 6,902 & 7,681 & 8,549 & 24.4 & 24.7 & 23.7 & 25.6 & 24.2 & 24.2 & 24.2 & 24.2 & 24.2 \\
\hline Other revenues & 487 & 440 & 440 & 440 & 440 & 500 & 527 & 555 & 618 & 2.7 & 2.2 & 2.1 & 2.0 & 1.9 & 1.9 & 1.8 & 1.7 & 1.7 \\
\hline Grants & 389 & 566 & 510 & 297 & 304 & 160.4 & 146 & 130 & 131 & 2.2 & 2.9 & 2.5 & 1.4 & 1.3 & 0.6 & 0.5 & 0.4 & 0.4 \\
\hline Current expenditures & 5,407 & 5,441 & 5,413 & 5,695 & 5,550 & 5,938 & 6,435 & 7,033 & 7,843 & 30.1 & 27.7 & 26.4 & 26.5 & 24.1 & 23.2 & 22.6 & 22.2 & 22.2 \\
\hline Compensation of employees & 1,048 & 1,151 & 1,151 & 1,209 & 1,208 & 1,280 & 1,410 & 1,540 & 1,714 & 5.8 & 5.9 & 5.6 & 5.6 & 5.2 & 5.0 & 4.9 & 4.9 & 4.9 \\
\hline Use of goods and services & 1,105 & 1,062 & 1,062 & 1,100 & 1,016 & 1,130 & 1,220 & 1,370 & 1,525 & 6.1 & 5.4 & 5.2 & 5.1 & 4.4 & 4.4 & 4.3 & 4.3 & 4.3 \\
\hline Subsidies & 420 & 384 & 384 & 380 & 380 & 380 & 390 & 430 & 479 & 2.3 & 2.0 & 1.9 & 1.8 & 1.6 & 1.5 & 1.4 & 1.4 & 1.4 \\
\hline Grants & 14 & 12 & 12 & 19 & 12 & 20 & 22 & 24 & 27 & 0.1 & 0.1 & 0.1 & 0.1 & 0.1 & 0.1 & 0.1 & 0.1 & 0.1 \\
\hline Social expenses & 1,506 & 1,611 & 1,611 & 1,717 & 1,631 & 1,820 & 2,020 & 2,220 & 2,471 & 8.4 & 8.2 & 7.9 & 8.0 & 7.1 & 7.1 & 7.1 & 7.0 & 7.0 \\
\hline Other expenses & 1,142 & 969 & 969 & 967 & 1,013 & 970 & 940 & 1,030 & 1,146 & 6.3 & 4.9 & 4.7 & 4.5 & 4.4 & 3.8 & 3.3 & 3.2 & 3.2 \\
\hline Interest & 171 & 252 & 224 & 303 & 292 & 338 & 433 & 419 & 481 & 1.0 & 1.3 & 1.1 & 1.4 & 1.3 & 1.3 & 1.5 & 1.3 & 1.4 \\
\hline To nonresidents & 113 & 171 & 160 & 184 & 191 & 184 & 275 & 254 & 254 & 0.6 & 0.9 & 0.8 & 0.9 & 0.8 & 0.7 & 1.0 & 0.8 & 0.7 \\
\hline To residents & 58 & 81 & 64 & 119 & 101 & 154 & 158 & 165 & 228 & 0.3 & 0.4 & 0.3 & 0.6 & 0.4 & 0.6 & 0.6 & 0.5 & 0.6 \\
\hline Operating balance & -143 & 424 & 397 & 542 & 765 & 923 & 1,140 & 1,334 & 1,456 & -0.8 & 2.2 & 1.9 & 2.5 & 3.3 & 3.6 & 4.0 & 4.2 & 4.1 \\
\hline Capital spending and net lending & 1,506 & 1,664 & 1,794 & 1,580 & 1,748 & 1,770 & 1,850 & 1,940 & 2,159 & 8.4 & 8.5 & 8.8 & 7.4 & 7.6 & 6.9 & 6.5 & 6.1 & 6.1 \\
\hline Capital & 1,444 & 1,702 & 1,674 & 1,580 & 1,630 & 1,660 & 1,690 & 1,890 & 2,104 & 8.0 & 8.7 & 8.2 & 7.4 & 7.1 & 6.5 & 5.9 & 6.0 & 6.0 \\
\hline Net lending & 62 & -37 & 120 & 0 & 118 & 110 & 160 & 50 & 56 & 0.3 & -0.2 & 0.6 & 0.0 & 0.5 & 0.4 & 0.6 & 0.2 & 0.2 \\
\hline Overall balance & $-1,648$ & $-1,241$ & $-1,397$ & $-1,038$ & -983 & -847 & -710 & -606 & -703 & -9.2 & -6.3 & -6.8 & -4.8 & -4.3 & -3.3 & -2.5 & -1.9 & -2.0 \\
\hline Statistical discrepancy & 0 & 0 & 0 & 0 & 0 & 0 & 0 & 0 & 0 & 0.0 & 0.0 & 0.0 & 0.0 & 0.0 & 0.0 & 0.0 & 0.0 & 0.0 \\
\hline Total financing & 1,648 & 1,241 & 1,397 & 1,038 & 983 & 847 & 710 & 606 & 703 & 9.2 & 6.3 & 6.8 & 4.8 & 4.3 & 3.3 & 2.5 & 1.9 & 2.0 \\
\hline Domestic & 596 & -62 & 42 & 378 & 209 & 216 & -49 & 213 & 856 & 3.3 & -0.3 & 0.2 & 1.8 & 0.9 & 0.8 & -0.2 & 0.7 & 2.4 \\
\hline Net T-bill issuance & 260 & 100 & 171 & 293 & 100 & 251 & -14 & 248 & 891 & 1.4 & 0.5 & 0.8 & 1.4 & 0.4 & 1.0 & 0.0 & 0.8 & 2.5 \\
\hline Amortization 21 & -37 & -35 & -39 & -42 & -35 & -35 & -35 & -35 & -35 & -0.2 & -0.2 & -0.2 & -0.2 & -0.2 & -0.1 & -0.1 & -0.1 & -0.1 \\
\hline Use of deposits at the NBG and banks & 373 & -127 & -91 & 127 & 144 & 0 & 0 & 0 & 0 & 2.1 & -0.6 & -0.4 & 0.6 & 0.6 & 0.0 & 0.0 & 0.0 & 0.0 \\
\hline External & 694 & 1,093 & 1,155 & 510 & 624 & 531 & 709 & 343 & -152 & 3.9 & 5.6 & 5.6 & 2.4 & 2.7 & 2.1 & 2.5 & 1.1 & -0.4 \\
\hline Borrowing & 787 & 1,241 & 1,291 & 644 & 761 & 651 & 2,220 & 672 & 697 & 4.4 & 6.3 & 6.3 & 3.0 & 3.3 & 2.5 & 7.8 & 2.1 & 2.0 \\
\hline of which: IMF & 170 & 524 & 523 & & 0 & & & & & 0.9 & 2.7 & 2.6 & 0.0 & 0.0 & 0.0 & 0.0 & 0.0 & 0.0 \\
\hline Amortization & -133 & -148 & -136 & -134 & -137 & -120 & $-1,511$ & -329 & -849 & -0.7 & -0.8 & -0.7 & -0.6 & -0.6 & -0.5 & -5.3 & -1.0 & -2.4 \\
\hline Use of Sovereign Wealth Fund resources & 40 & 0 & 0 & 0 & 0 & 0 & 0 & 0 & 0 & 0.2 & 0.0 & 0.0 & 0.0 & 0.0 & 0.0 & 0.0 & 0.0 & 0.0 \\
\hline Privatization receipts & 358 & 210 & 200 & 150 & 150 & 100 & 50 & 50 & 0 & 2.0 & 1.1 & 1.0 & 0.7 & 0.7 & 0.4 & 0.2 & 0.2 & 0.0 \\
\hline \multicolumn{19}{|l|}{ Memorandum items: } \\
\hline Nominal GDP & 17,986 & 19,657 & 20,490 & 21,465 & 23,018 & 25,619 & 28,514 & 31,737 & 35,323 & & & & & & & & & \\
\hline Fiscal deficit excluding grants & 2,037 & 1,807 & 1,907 & 1,335 & 1,287 & 1,008 & 856 & 736 & 834 & 11.3 & 9.2 & 9.3 & 6.2 & 5.6 & 3.9 & 3.0 & 2.3 & 2.4 \\
\hline Total expenditures (current prices) 3/ & 6,913 & 7,106 & 7,206 & 7,275 & 7,298 & 7,708 & 8,285 & 8,973 & 10,002 & 38.4 & 36.1 & 35.2 & 33.9 & 31.7 & 30.1 & 29.1 & 28.3 & 28.3 \\
\hline Total expenditures (constant 2008 prices) & 7,055 & & 6,859 & & 6,461 & 6,438 & 6,528 & 6,670 & 7,014 & & & & & & & & & \\
\hline
\end{tabular}


Table 3. Georgia: Quarterly General Government Operations, 2009-11 1/

\begin{tabular}{|c|c|c|c|c|c|c|c|c|c|c|c|c|c|c|c|}
\hline & \multicolumn{5}{|c|}{2009} & \multicolumn{5}{|c|}{2010} & \multicolumn{5}{|c|}{2011} \\
\hline & $\begin{array}{r}\text { Q1 } \\
\text { Act. }\end{array}$ & $\begin{array}{r}\text { Q2 } \\
\text { Act. }\end{array}$ & $\begin{array}{r}\text { Q3 } \\
\text { Act. }\end{array}$ & $\begin{array}{r}\text { Q4 } \\
\text { Act. }\end{array}$ & $\begin{array}{c}\text { Annual } \\
\text { Act. }\end{array}$ & $\begin{array}{r}\text { Q1 } \\
\text { Act. }\end{array}$ & $\begin{array}{r}\text { Q2 } \\
\text { Act. }\end{array}$ & $\begin{array}{r}\text { Q3 } \\
\text { Act. }\end{array}$ & $\begin{array}{c}\text { Q4 } \\
\text { Proj. }\end{array}$ & $\begin{array}{c}\text { Annual } \\
\text { Proj. }\end{array}$ & $\begin{array}{c}\text { Q1 } \\
\text { Proj. }\end{array}$ & $\begin{array}{c}\text { Q2 } \\
\text { Proj. }\end{array}$ & $\begin{array}{c}\text { Q3 } \\
\text { Proj. }\end{array}$ & $\begin{array}{c}\text { Q4 } \\
\text { Proj. }\end{array}$ & $\begin{array}{c}\text { Annual } \\
\text { Proj. }\end{array}$ \\
\hline & \multicolumn{15}{|c|}{ (In millions of lari) } \\
\hline Revenues & 1,267 & 1,118 & 1,292 & 1,588 & 5,264 & 1,318 & 1,436 & 1,481 & 1,574 & 5,809 & 1,383 & 1,550 & 1,624 & 1,758 & 6,315 \\
\hline Taxes & 1,139 & 996 & 1,094 & 1,159 & 4,389 & 1,130 & 1,229 & 1,229 & 1,273 & 4,860 & 1,247 & 1,395 & 1,449 & 1,480 & 5,571 \\
\hline Direct & 458 & 452 & 475 & 473 & 1,858 & 511 & 515 & 479 & 500 & 2,004 & 532 & 569 & 586 & 567 & 2,253 \\
\hline Indirect & 681 & 544 & 619 & 687 & 2,531 & 619 & 714 & 750 & 773 & 2,856 & 715 & 826 & 863 & 913 & 3,318 \\
\hline Other revenues & 79 & 84 & 107 & 217 & 487 & 97 & 147 & 120 & 76 & 440 & 71 & 81 & 99 & 189 & 440 \\
\hline Grants & 48 & 38 & 90 & 212 & 389 & 92 & 60 & 133 & 225 & 510 & 65 & 73 & 77 & 89 & 304 \\
\hline Current expenditures & 1,296 & 1,300 & 1,282 & 1,529 & 5,407 & 1,208 & 1,380 & 1,343 & 1,481 & 5,413 & 1,254 & 1,379 & 1,411 & 1,506 & 5,550 \\
\hline Employee compensation & 248 & 260 & 251 & 289 & 1,048 & 263 & 288 & 268 & 333 & 1,151 & 270 & 290 & 295 & 353 & 1,208 \\
\hline Use of goods and services & 207 & 273 & 260 & 365 & 1,105 & 203 & 273 & 286 & 300 & 1,062 & 202 & 248 & 275 & 291 & 1,016 \\
\hline Subsidies & 87 & 105 & 104 & 125 & 420 & 85 & 99 & 90 & 110 & 384 & 90 & 95 & 97 & 98 & 380 \\
\hline Grants & 7 & 3 & 2 & 3 & 14 & 5 & 2 & 3 & 2 & 12 & 3 & 3 & 3 & 3 & 12 \\
\hline Social expenses & 352 & 377 & 377 & 400 & 1,506 & 399 & 408 & 402 & 402 & 1,611 & 408 & 408 & 408 & 408 & 1,631 \\
\hline Other expenses & 370 & 226 & 259 & 288 & 1,142 & 220 & 246 & 256 & 248 & 969 & 225 & 248 & 273 & 267 & 1,013 \\
\hline Interest & 26 & 56 & 30 & 59 & 171 & 33 & 65 & 39 & 87 & 224 & 56 & 87 & 60 & 88 & 292 \\
\hline To nonresidents & 13 & 40 & 16 & 45 & 113 & 17 & 48 & 21 & 74 & 160 & 33 & 60 & 33 & 65 & 191 \\
\hline To residents & 13 & 16 & 14 & 15 & 58 & 16 & 18 & 18 & 13 & 64 & 23 & 28 & 28 & 23 & 101 \\
\hline Operating balance & -30 & -182 & 9 & 59 & -143 & 110 & 56 & 138 & 93 & 397 & 129 & 171 & 213 & 252 & 765 \\
\hline Capital spending and net lending & 199 & 338 & 474 & 495 & 1,506 & 206 & 412 & 459 & 717 & 1,794 & 299 & 441 & 461 & 547 & 1,748 \\
\hline Capital & 169 & 333 & 452 & 490 & 1444 & 233 & 422 & 402 & 619 & 1,674 & 256 & 413 & 441 & 521 & 1,630 \\
\hline Net lending & 30 & 5 & 22 & 5 & 62 & -27 & -10 & 57 & 98 & 120 & 43 & 28 & 21 & 26 & 118 \\
\hline Overall balance & -228 & -520 & -464 & -436 & $-1,648$ & -96 & -356 & -321 & -624 & $-1,397$ & -170 & -270 & -248 & -295 & -983 \\
\hline Statistical discrepancy & 0 & 0 & 0 & 0 & 0 & 0 & 0 & 0 & 0 & 0 & 0 & 0 & 0 & 0 & 0 \\
\hline Total financing & 228 & 520 & 464 & 436 & 1,648 & 96 & 356 & 321 & 624 & 1,397 & 170 & 270 & 248 & 295 & 983 \\
\hline Domestic & 63 & 375 & 103 & 55 & 596 & -348 & 283 & -60 & 167 & 42 & 72 & 153 & 35 & -51 & 209 \\
\hline Net T-Bill issuance & 0 & 0 & 68 & 192 & 260 & 67 & 41 & 63 & 0 & 171 & 9 & 9 & 38 & 45 & 100 \\
\hline Amortization 2/ & -9 & -11 & -12 & -5 & -37 & -12 & -14 & -9 & -4 & -39 & -5 & -12 & -10 & -8 & -35 \\
\hline Use of deposits at the NBG and banks & 72 & 386 & 48 & -132 & 373 & -403 & 255 & -115 & 172 & -91 & 69 & 156 & 7 & -88 & 144 \\
\hline External & 64 & 40 & 301 & 289 & 694 & 411 & 45 & 304 & 396 & 1,155 & 71 & 91 & 170 & 292 & 624 \\
\hline Borrowing & 37 & 60 & 377 & 313 & 787 & 424 & 65 & 370 & 431 & 1,291 & 94 & 117 & 225 & 324 & 761 \\
\hline Of which: IMF & 0 & 0 & 0 & 170 & 170 & 385 & 0 & 138 & 0 & 523 & 0 & 0 & 0 & 0 & 0 \\
\hline Amortization & -13 & -20 & -76 & -24 & -133 & -13 & -20 & -67 & -36 & -136 & -23 & -27 & -56 & -31 & -137 \\
\hline Use of Sovereign Wealth Fund resources & 40 & 0 & 0 & 0 & 40 & 0 & 0 & 0 & 0 & 0 & 0 & 0 & 0 & 0 & 0 \\
\hline Privatization receipts & 101 & 106 & 60 & 91 & 358 & 33 & 29 & 78 & 61 & 200 & 26 & 27 & 43 & 54 & 150 \\
\hline \multicolumn{16}{|l|}{ Memorandum items: } \\
\hline Nominal GDP & 3,971 & 4,275 & 4,590 & 5,149 & 17,986 & 4,294 & 5,044 & 5,429 & 5,723 & 20,490 & 4,862 & 5,647 & 5,991 & 6,519 & 23,018 \\
\hline Total expenditures $3 /$ & 1,495 & 1,638 & 1,756 & 2,024 & 6,913 & 1,414 & 1,792 & 1,802 & 2,198 & 7,206 & 1,553 & 1,820 & 1,872 & 2,053 & 7,298 \\
\hline
\end{tabular}

Sources: Ministry of Finance; and Fund staff estimates.

1/ General government includes central and local governments and the Sovereign Wealth Funds.

2/ Excluding arrears clearance, provisions and T-bill repayment.

$3 /$ Including net lending. 
Table 4. Georgia: Summary Balance of Payments, 2008-15 (In millions of U.S. dollars)

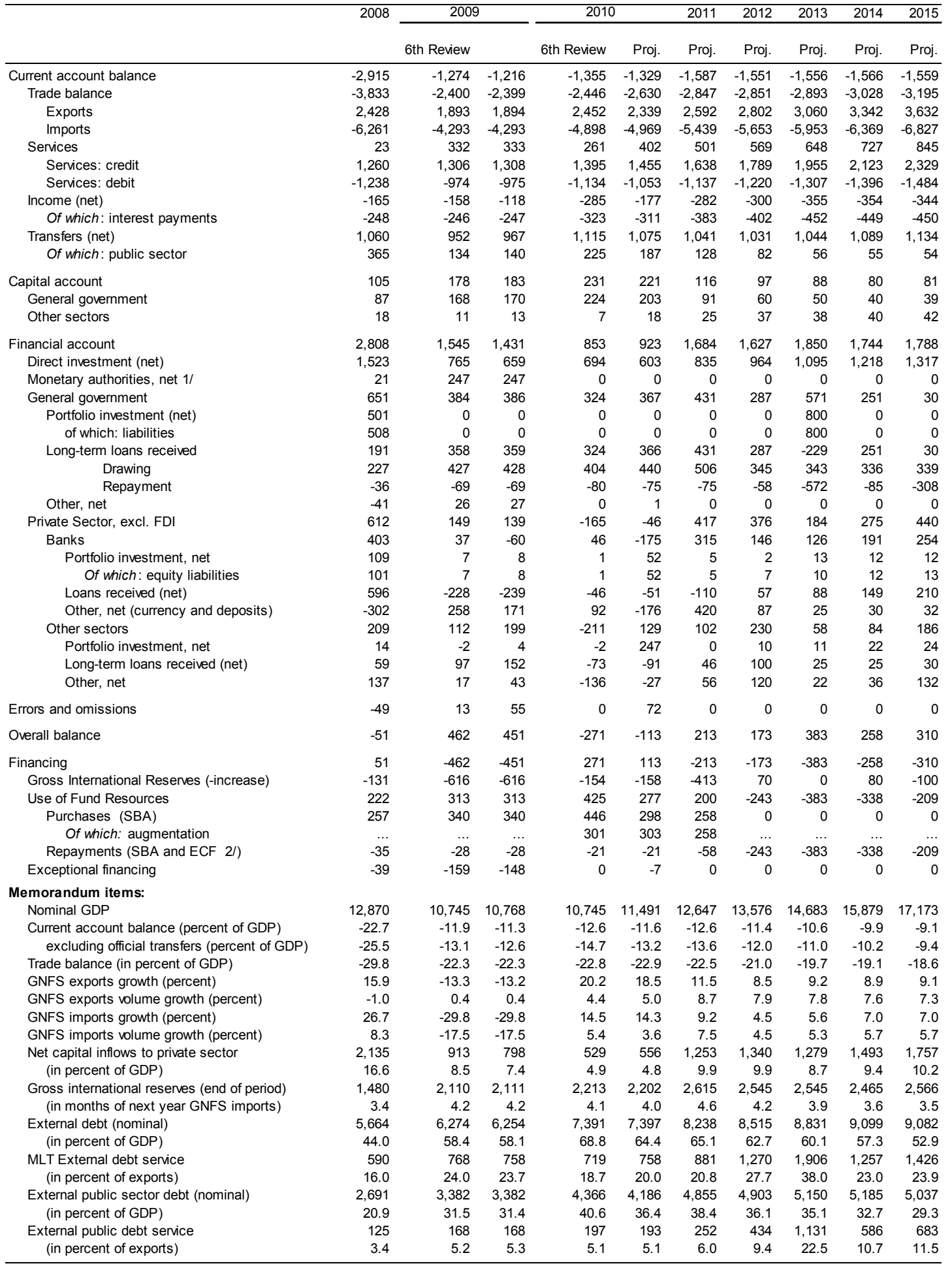

Sources: National Bank of Georgia, Ministry of Finance, and Fund staff estimates.

1/ SDR allocation included under monetary authorities' long-term liabilities.

2/ Following the Low Income Countries (LIC) reforms, effective January 7 2010, the PRGF arrangements were renamed Extended Credit Facility (ECF) arrangements. 
Table 5. Georgia: Accounts of the National Bank of Georgia, 2009-11

\begin{tabular}{|c|c|c|c|c|c|c|c|c|c|c|c|c|}
\hline & \multicolumn{4}{|c|}{2009} & \multicolumn{4}{|c|}{2010} & \multicolumn{4}{|c|}{2011} \\
\hline & $\begin{array}{l}\text { Mar. } \\
\text { Act. }\end{array}$ & $\begin{array}{l}\text { Jun. } \\
\text { Act. }\end{array}$ & $\begin{array}{l}\text { Sep. } \\
\text { Act. }\end{array}$ & $\begin{array}{l}\text { Dec. } \\
\text { Act. }\end{array}$ & $\begin{array}{l}\text { Mar. } \\
\text { Act. }\end{array}$ & $\begin{array}{l}\text { Jun. } \\
\text { Act. } \\
\end{array}$ & $\begin{array}{l}\text { Sep. } \\
\text { Act. }\end{array}$ & $\begin{array}{l}\text { Dec. } \\
\text { Proj. }\end{array}$ & $\begin{array}{l}\text { Mar. } \\
\text { Proj. }\end{array}$ & $\begin{array}{l}\text { Jun. } \\
\text { Proj. } \\
\end{array}$ & $\begin{array}{l}\text { Sep. } \\
\text { Proj. }\end{array}$ & $\begin{array}{l}\text { Dec. } \\
\text { Proj. }\end{array}$ \\
\hline & \multicolumn{12}{|c|}{ (In millions of lari) } \\
\hline Net foreign exchange position & 1,313 & 1,303 & 1,489 & 1,842 & 2,117 & 1,698 & 1,961 & 2,124 & 2,027 & 2,068 & 2,143 & 2,321 \\
\hline Gross International Reserves & 2,493 & 2,517 & 3,371 & 3,558 & 3,847 & 3,438 & 3,812 & 3,920 & 4,340 & 4,606 & 4,711 & 4,865 \\
\hline Other foreign assets & 35 & 14 & 15 & 5 & 6 & 5 & 5 & 5 & 5 & 5 & 5 & 5 \\
\hline Foreign currency liabilities & $-1,215$ & $-1,228$ & $-1,896$ & $-1,722$ & $-1,736$ & $-1,746$ & $-1,856$ & $-1,801$ & $-2,318$ & $-2,543$ & $-2,572$ & $-2,549$ \\
\hline Of which: use of Fund resources & $-1,040$ & $-1,068$ & $-1,330$ & $-1,149$ & $-1,143$ & $-1,165$ & $-1,186$ & $-1,142$ & $-1,410$ & $-1,614$ & $-1,618$ & $-1,568$ \\
\hline Of which: compulsory reserves in USD & -125 & -109 & -122 & -127 & -142 & -148 & -242 & -247 & -491 & -508 & -529 & -550 \\
\hline Of which: swap liabilities & 0 & -30 & -61 & -61 & -63 & -33 & 0 & 0 & 0 & 0 & 0 & 0 \\
\hline Net domestic assets & -47 & 226 & 201 & -98 & -484 & -37 & -265 & -277 & -245 & -232 & -277 & -361 \\
\hline Net claims on general government & -34 & 398 & 441 & 173 & -194 & 52 & -73 & 36 & 82 & 175 & 116 & -19 \\
\hline Claims on general government (incl. T-bills) & 777 & 778 & 764 & 758 & 746 & 733 & 718 & 711 & 704 & 699 & 687 & 677 \\
\hline Nontradable govt. debt & 641 & 641 & 641 & 641 & 601 & 601 & 601 & 601 & 553 & 553 & 553 & 553 \\
\hline Securitized debt (marketable) & 136 & 137 & 123 & 118 & 146 & 132 & 117 & 110 & 151 & 146 & 134 & 124 \\
\hline Deposits & -812 & -380 & -323 & -585 & -940 & -681 & -790 & -674 & -621 & -523 & -570 & -695 \\
\hline Claims on rest of economy & 4 & 4 & 4 & 3 & 3 & 3 & 2 & 2 & 2 & 2 & 2 & 2 \\
\hline Claims on banks & 90 & -17 & -41 & -114 & -89 & 57 & -7 & -127 & -117 & -174 & -136 & -62 \\
\hline Bank refinancing & 204 & 102 & 45 & 45 & 45 & 217 & 185 & 185 & 185 & 185 & 185 & 185 \\
\hline Certificates of deposits and bonds & -114 & -148 & -146 & -219 & -194 & -190 & -192 & -312 & -302 & -359 & -321 & -247 \\
\hline Other items, net & -106 & -160 & -203 & -160 & -204 & -149 & -188 & -189 & -213 & -236 & -259 & -283 \\
\hline Reserve money & 1,267 & 1,529 & 1,691 & 1,744 & 1,633 & 1,661 & 1,696 & 1,848 & 1,781 & 1,836 & 1,866 & 1,959 \\
\hline Currency in circulation & 1,141 & 1,201 & 1,286 & 1,458 & 1,399 & 1,460 & 1,501 & 1,650 & 1,575 & 1,625 & 1,650 & 1,750 \\
\hline Bank lari reserves $1 /$ & 126 & 328 & 405 & 286 & 235 & 127 & 150 & 152 & 161 & 166 & 171 & 164 \\
\hline \multirow[t]{2}{*}{ Overnight deposits } & 0 & 0 & 0 & 0 & 0 & 74 & 45 & 45 & 45 & 45 & 45 & 45 \\
\hline & \multicolumn{12}{|c|}{ (Percent contribution, compared to reserve money at the end of previous year) } \\
\hline Net foreign exchange position & -15.0 & -15.7 & -2.7 & 21.9 & 15.8 & -8.2 & 6.8 & 16.2 & -5.3 & -3.0 & 1.0 & 10.6 \\
\hline Net domestic assets & 3.4 & 22.5 & 20.8 & -0.1 & -22.2 & 3.5 & -9.6 & -10.3 & 1.7 & 2.4 & 0.0 & -4.6 \\
\hline Net claims on general government & 4.8 & 35.0 & 38.0 & 19.3 & -21.1 & -7.0 & -14.1 & -7.8 & 2.5 & 7.5 & 4.3 & -3.0 \\
\hline Claims on rest of economy & 0.0 & 0.0 & 0.0 & 0.0 & 0.0 & 0.0 & 0.0 & 0.0 & 0.0 & 0.0 & 0.0 & 0.0 \\
\hline Claims on banks & -2.9 & -10.4 & -12.1 & -17.2 & 1.4 & 9.8 & 6.1 & -0.7 & 0.5 & -2.6 & -0.5 & 3.5 \\
\hline \multirow[t]{2}{*}{ Other items, net } & 1.6 & -2.2 & -5.1 & -2.2 & -2.5 & 0.7 & -1.6 & -1.7 & -1.3 & -2.5 & -3.8 & -5.1 \\
\hline & \multicolumn{12}{|c|}{ (Percentage change, relative to end of previous year) } \\
\hline Reserve money & -11.5 & 6.8 & 18.1 & 21.8 & -6.3 & -4.8 & -2.8 & 5.9 & -3.6 & -0.6 & 1.0 & 6.1 \\
\hline Currency in circulation & -11.6 & -6.9 & -0.4 & 13.0 & -4.1 & 0.2 & 2.9 & 13.2 & -4.5 & -1.5 & 0.0 & 6.1 \\
\hline Bank lari reserves $1 /$ & -11.0 & 132.0 & 186.9 & 102.5 & -18.0 & -55.8 & -47.7 & -46.7 & 5.8 & 8.9 & 12.1 & 7.8 \\
\hline \multirow{2}{*}{\multicolumn{13}{|c|}{$\begin{array}{l}\text { Memorandum items: } \\
\text { Net international reserves }\end{array}$}} \\
\hline & & & & & & & & & & & & \\
\hline (in millions of USD, at prog. exchange rates) $2 /$ & 777 & 775 & 876 & 987 & 897 & 647 & 708 & 825 & 757 & 771 & 805 & 885 \\
\hline Net domestic assets (in millions of lari, at prog. exchange rate) 2/ & -66 & 189 & 228 & 95 & 135 & 579 & 513 & 470 & 516 & 548 & 521 & 481 \\
\hline Reserve money (in percent, 12-month growth) & -10.4 & -4.5 & -2.5 & 21.8 & 28.9 & 8.6 & 0.3 & 5.9 & 9.1 & 8.5 & 12.4 & 6.1 \\
\hline
\end{tabular}

Sources: National Bank of Georgia; and Fund staff estimates

$1 /$ Comprises required and excess reserves on lari-denominated deposits.

2/ Based on program definition as defined in the TMU. 
Table 6. Georgia: Monetary Survey, 2009-11

\begin{tabular}{|c|c|c|c|c|c|c|c|c|c|c|c|c|}
\hline & \multicolumn{4}{|c|}{2009} & \multicolumn{4}{|c|}{2010} & \multicolumn{4}{|c|}{2011} \\
\hline & $\begin{array}{l}\text { Mar. } \\
\text { Act. }\end{array}$ & $\begin{array}{l}\text { Jun. } \\
\text { Act. }\end{array}$ & $\begin{array}{l}\text { Sep. } \\
\text { Act. }\end{array}$ & $\begin{array}{l}\text { Dec. } \\
\text { Act. }\end{array}$ & $\begin{array}{l}\text { Mar. } \\
\text { Act. }\end{array}$ & $\begin{array}{l}\text { Jun. } \\
\text { Act. }\end{array}$ & $\begin{array}{l}\text { Sep. } \\
\text { Act. }\end{array}$ & $\begin{array}{l}\text { Dec. } \\
\text { Proj. }\end{array}$ & $\begin{array}{l}\text { Mar. } \\
\text { Proj. }\end{array}$ & $\begin{array}{l}\text { Jun. } \\
\text { Proj. }\end{array}$ & $\begin{array}{l}\text { Sep. } \\
\text { Proj. }\end{array}$ & $\begin{array}{l}\text { Dec. } \\
\text { Proj. }\end{array}$ \\
\hline & \multicolumn{12}{|c|}{ (In millions of lari) } \\
\hline Net foreign assets & -356 & -357 & 240 & 789 & 1,067 & 800 & 1,249 & 1,340 & 1,343 & 1,357 & 1,455 & 1,563 \\
\hline NBG & 1,438 & 1,442 & 1,672 & 2,030 & 2,323 & 1,880 & 2,203 & 2,371 & 2,518 & 2,576 & 2,671 & 2,871 \\
\hline Commercial banks $1 /$ & $-1,794$ & $-1,800$ & $-1,432$ & $-1,241$ & $-1,256$ & $-1,079$ & -954 & $-1,031$ & $-1,175$ & $-1,219$ & $-1,216$ & $-1,307$ \\
\hline Of which: liabilities & $-2,760$ & $-2,446$ & $-2,319$ & $-2,229$ & $-2,197$ & $-2,303$ & $-2,157$ & $-2,216$ & $-2,129$ & $-2,184$ & $-2,192$ & $-2,293$ \\
\hline Net domestic assets & 4,031 & 3,952 & 3,852 & 3,814 & 3,669 & 4,242 & 4,139 & 4,275 & 4,577 & 4,794 & 5,010 & 5,175 \\
\hline Domestic credit & 5,644 & 5,733 & 5,676 & 5,539 & 5,418 & 6,041 & 6,125 & 6,253 & 6,586 & 6,832 & 7,077 & 7,272 \\
\hline Net claims on general government & -114 & 270 & 387 & 280 & -5 & 230 & 206 & 316 & 370 & 472 & 451 & 361 \\
\hline Of which: government deposits at NBG & -812 & -380 & -323 & -585 & -940 & -681 & -790 & -674 & -621 & -523 & -570 & -695 \\
\hline Of which: T-bills at commercial banks & & & 68 & 260 & 326 & 368 & 431 & 431 & 439 & 448 & 486 & 531 \\
\hline Credit to the rest of the economy & 5,758 & 5,462 & 5,289 & 5,259 & 5,423 & 5,811 & 5,919 & 5,937 & 6,216 & 6,360 & 6,626 & 6,911 \\
\hline Other items, net & $-1,613$ & $-1,781$ & $-1,824$ & $-1,725$ & $-1,749$ & $-1,799$ & $-1,986$ & $-1,978$ & $-2,008$ & $-2,037$ & $-2,067$ & $-2,097$ \\
\hline Broad money (M3) 1/ & 3,675 & 3,594 & 4,092 & 4,603 & 4,736 & 5,042 & 5,388 & 5,615 & 5,920 & 6,152 & 6,465 & 6,738 \\
\hline Broad money, excl. forex deposits (M2) & 1,634 & 1,709 & 1,914 & 2,133 & 2,215 & 2,347 & 2,458 & 2,630 & 2,676 & 2,789 & 2,910 & 3,073 \\
\hline Currency held by the public & 960 & 1,020 & 1,093 & 1,229 & 1,187 & 1,269 & 1,307 & 1,456 & 1,381 & 1,431 & 1,456 & 1,556 \\
\hline \multirow[t]{2}{*}{ Total deposit liabilities } & 2,715 & 2,574 & 2,999 & 3,373 & 3,549 & 3,773 & 4,081 & 4,159 & 4,539 & 4,721 & 5,009 & 5,182 \\
\hline & \multicolumn{12}{|c|}{ (Percent contribution, compared to broad money at the end of previous year) } \\
\hline Net foreign assets & -10.2 & -10.3 & 3.8 & 16.7 & 6.0 & 0.3 & 10.0 & 12.0 & 0.1 & 0.3 & 2.0 & 4.0 \\
\hline Net domestic assets & -3.5 & -5.3 & -7.7 & -8.6 & -3.1 & 9.3 & 7.1 & 10.0 & 5.4 & 9.2 & 13.1 & 16.0 \\
\hline Domestic credit & -6.5 & -4.4 & -5.8 & -9.0 & -2.6 & 10.9 & 12.7 & 15.5 & 5.9 & 10.3 & 14.7 & 18.1 \\
\hline Net claims on general government & 1.0 & 10.0 & 12.7 & 10.2 & -6.2 & -1.1 & -1.6 & 0.8 & 1.0 & 2.8 & 2.4 & 0.8 \\
\hline Credit to the rest of the economy & -7.5 & -14.4 & -18.5 & -19.2 & 3.6 & 12.0 & 14.3 & 14.7 & 5.0 & 7.5 & 12.3 & 17.3 \\
\hline \multirow[t]{2}{*}{ Other items, net } & 3.0 & -0.9 & -1.9 & 0.4 & -0.5 & -1.6 & -5.7 & -5.5 & -0.5 & -1.1 & -1.6 & -2.1 \\
\hline & \multicolumn{12}{|c|}{ (Percentage change, relative to end of previous year) } \\
\hline Broad money (M3) & -13.7 & -15.6 & -3.9 & 8.1 & 2.9 & 9.6 & 17.1 & 22.0 & 5.4 & 9.6 & 15.1 & 20.0 \\
\hline Broad money, excl. forex deposits (M2) & -11.9 & -7.8 & 3.2 & 15.0 & 3.9 & 10.1 & 15.3 & 23.3 & 1.7 & 6.1 & 10.6 & 16.9 \\
\hline Currency held by the public & -11.3 & -5.7 & 1.0 & 13.6 & -3.5 & 3.3 & 6.3 & 18.4 & -5.2 & -1.7 & 0.0 & 6.9 \\
\hline Total deposit liabilities & -14.5 & -19.0 & -5.6 & 6.2 & 5.2 & 11.8 & 21.0 & 23.3 & 9.1 & 13.5 & 20.4 & 24.6 \\
\hline Credit to the rest of the economy & -5.2 & -10.1 & -13.0 & -13.5 & 3.1 & 10.5 & 12.5 & 12.9 & 4.7 & 7.1 & 11.6 & 16.4 \\
\hline \multicolumn{13}{|l|}{ Memorandum items: } \\
\hline M3 (in percent, 12-month growth) & -8.7 & -14.2 & 3.2 & 8.1 & 28.9 & 40.3 & 31.7 & 22.0 & 5.4 & 9.6 & 15.1 & 20.0 \\
\hline M2 (in percent, 12-month growth) & -27.7 & -29.3 & -15.2 & 15.0 & 35.6 & 37.3 & 28.5 & 23.3 & 1.7 & 6.1 & 10.6 & 16.9 \\
\hline Credit to the economy (in percent, 12-month growth) & 13.6 & -2.4 & -4.0 & -13.5 & -5.8 & 6.4 & 11.9 & 12.9 & 4.7 & 7.1 & 11.6 & 16.4 \\
\hline Ratio of bank lari reserves to lari deposits $2 /$ & 18.6 & 47.6 & 49.4 & 31.7 & 22.8 & 18.6 & 16.9 & 16.8 & 15.9 & 15.5 & 14.9 & 13.8 \\
\hline M3 multiplier & 2.64 & 2.19 & 2.26 & 2.46 & 2.67 & 2.79 & 2.89 & 2.78 & 2.78 & 2.81 & 2.88 & 2.87 \\
\hline M3 velocity & 5.13 & 5.06 & 4.40 & 3.91 & 3.87 & 4.06 & 3.70 & 3.65 & 3.56 & 3.52 & 3.44 & 3.42 \\
\hline Foreign exchange deposits in percent of total deposits & 75.2 & 73.2 & 72.6 & 73.2 & 71.0 & 71.4 & 71.8 & 71.8 & 71.5 & 71.2 & 71.0 & 70.7 \\
\hline
\end{tabular}

Sources: National Bank of Georgia; and Fund staff estimates.

1/ The proceeds of the Georgian Railway eurobond issuance from July 2010, which were deposited in accounts with Georgian commercial banks that placed them abroad, are subtracted fron commercial banks' foreign assets and domestic $\mathrm{fx}$ deposits.

2/ Comprises required and excess reserves on lari-denominated deposits (excess reserves include overnight deposits with NBG). 
Table 7. Georgia: External Vulnerability Indicators, 2008-15

\begin{tabular}{|c|c|c|c|c|c|c|c|c|}
\hline & $\begin{array}{c}2008 \\
\text { Act. }\end{array}$ & $\begin{array}{c}2009 \\
\text { Act. }\end{array}$ & $\begin{array}{l}2010 \\
\text { Proj. }\end{array}$ & $\begin{array}{l}2011 \\
\text { Proj. }\end{array}$ & $\begin{array}{l}2012 \\
\text { Proj. }\end{array}$ & $\begin{array}{l}2013 \\
\text { Proj. }\end{array}$ & $\begin{array}{l}2014 \\
\text { Proj. }\end{array}$ & $\begin{array}{l}2015 \\
\text { Proj. }\end{array}$ \\
\hline Value of exports of goods and services, percent change & 15.9 & -13.2 & 18.5 & 11.5 & 8.5 & 9.2 & 8.9 & 9.1 \\
\hline Value of imports of goods and services, percent change & 26.7 & -29.8 & 14.3 & 9.2 & 4.5 & 5.6 & 7.0 & 7.0 \\
\hline Terms of trade (deterioration - ) & 0.1 & 1.5 & 2.4 & 1.0 & 0.5 & 1.0 & 0.1 & 0.5 \\
\hline Current account balance (percent of GDP) & -22.7 & -11.3 & -11.6 & -12.6 & -11.4 & -10.6 & -9.9 & -9.1 \\
\hline Capital and financial account (percent of GDP) & 22.6 & 15.0 & 10.0 & 14.2 & 12.7 & 13.2 & 11.5 & 10.9 \\
\hline External public debt (percent of GDP) & 20.9 & 31.4 & 36.4 & 38.4 & 36.1 & 35.1 & 32.7 & 29.3 \\
\hline in percent of exports of goods and services & 73.0 & 105.6 & 110.3 & 114.8 & 106.8 & 102.7 & 94.9 & 84.5 \\
\hline \multicolumn{9}{|l|}{ Debt service on external public debt } \\
\hline (in percent of exports of goods and services) & 3.4 & 5.3 & 5.1 & 6.0 & 9.4 & 22.5 & 10.7 & 11.5 \\
\hline External debt (percent of GDP) & 44.0 & 58.1 & 64.4 & 65.1 & 62.7 & 60.1 & 57.3 & 52.9 \\
\hline in percent of exports of goods and services & 153.6 & 195.3 & 194.9 & 194.7 & 185.5 & 176.1 & 166.5 & 152.4 \\
\hline \multicolumn{9}{|l|}{ Debt service on MLT external debt } \\
\hline (in percent of exports of goods and services) & 16.0 & 23.7 & 20.0 & 20.8 & 27.7 & 38.0 & 23.0 & 23.9 \\
\hline \multicolumn{9}{|l|}{ Gross international reserves } \\
\hline in millions of USD & 1,480 & 2,111 & 2,202 & 2,615 & 2,545 & 2,545 & 2,465 & 2,566 \\
\hline in months of next year's imports of goods and servces & 3.4 & 4.2 & 4.0 & 4.6 & 4.2 & 3.9 & 3.6 & 3.5 \\
\hline in percent of external debt & 26.1 & 33.7 & 29.8 & 31.7 & 29.9 & 28.8 & 27.1 & 28.2 \\
\hline in percent of short-term external debt (remaining maturity) & 101 & 162 & 156 & 141 & 107 & 157 & 135 & 114 \\
\hline
\end{tabular}

Source: Fund staff estimates and projections. 
Table 8. Georgia: Indicators of Fund Credit, 2008-17

(In millions of SDR)

\begin{tabular}{|c|c|c|c|c|c|c|c|c|c|c|}
\hline & 2008 & 2009 & $\begin{array}{l}2010 \\
\text { Proj. }\end{array}$ & $\begin{array}{l}2011 \\
\text { Proj. }\end{array}$ & $\begin{array}{l}2012 \\
\text { Proj. }\end{array}$ & $\begin{array}{l}2013 \\
\text { Proj. }\end{array}$ & $\begin{array}{l}2014 \\
\text { Proj. }\end{array}$ & $\begin{array}{l}2015 \\
\text { Proj. }\end{array}$ & $\begin{array}{l}2016 \\
\text { Proj. }\end{array}$ & $\begin{array}{l}2017 \\
\text { Proj. }\end{array}$ \\
\hline \multicolumn{11}{|l|}{ Existing Fund credit } \\
\hline Stock 1/ & 298.8 & 501.6 & 682.1 & 644.0 & 484.1 & 233.0 & 66.2 & 14.0 & 4.2 & 0.0 \\
\hline ECF 2/ & 137.1 & 119.1 & 105.0 & 87.1 & 67.2 & 47.6 & 29.4 & 14.0 & 4.2 & 0.0 \\
\hline SBA & 161.7 & 382.5 & 577.1 & 556.9 & 416.9 & 185.4 & 36.8 & 0.0 & 0.0 & 0.0 \\
\hline Obligations & 23.3 & 22.5 & 21.6 & 46.2 & 167.6 & 256.4 & 168.8 & 52.5 & 9.8 & 4.2 \\
\hline ECF 2/ & 22.8 & 18.6 & 14.1 & 17.9 & 20.1 & 19.7 & 18.3 & 15.5 & 9.8 & 4.2 \\
\hline SBA 3/ & 0.5 & 3.9 & 7.5 & 28.3 & 147.5 & 236.6 & 150.5 & 37.1 & 0.0 & 0.0 \\
\hline \multicolumn{11}{|l|}{ Prospective purchases under the SBA } \\
\hline Disbursements & $\ldots$ & $\ldots$ & 0.0 & 170.0 & 0.0 & 0.0 & 0.0 & 0.0 & 0.0 & 0.0 \\
\hline Stock 1/ & $\ldots$ & $\ldots$ & 0.0 & 170.0 & 170.0 & 170.0 & 115.0 & 30.0 & 0.0 & 0.0 \\
\hline Obligations $3 /$ & $\ldots$ & $\ldots$ & 0.0 & 1.6 & 2.4 & 2.4 & 57.2 & 86.2 & 30.1 & 0.0 \\
\hline Principal (repurchases) & $\ldots$ & $\ldots$ & 0.0 & 0.0 & 0.0 & 0.0 & 55.0 & 85.0 & 30.0 & 0.0 \\
\hline GRA charges & $\ldots$ & $\ldots$ & 0.0 & 1.6 & 2.4 & 2.4 & 2.2 & 1.2 & 0.1 & 0.0 \\
\hline Surcharges & $\ldots$ & $\ldots$ & 1.4 & 4.8 & 5.0 & 2.0 & 0.0 & 0.0 & 0.0 & 0.0 \\
\hline Stock of existing and prospective Fund credit $1 /$ & 298.8 & 501.6 & 682.1 & 814.0 & 654.1 & 403.0 & 181.2 & 44.0 & 4.2 & 0.0 \\
\hline In percent of quota & 198.8 & 333.7 & 453.8 & 541.6 & 435.2 & 268.1 & 120.6 & 29.3 & 2.8 & 0.0 \\
\hline In percent of GDP & 3.7 & 7.2 & 9.0 & 9.8 & 7.3 & 4.2 & 1.7 & 0.4 & 0.0 & 0.0 \\
\hline In percent of exports of goods and nonfactor services & 12.8 & 24.2 & 27.3 & 29.2 & 21.7 & 12.2 & 5.1 & 1.1 & 0.1 & 0.0 \\
\hline In percent of gross reserves & 31.9 & 36.7 & 47.0 & 47.3 & 39.1 & 24.1 & 11.2 & 2.6 & 0.2 & 0.0 \\
\hline In percent of public external debt & 17.5 & 22.9 & 24.7 & 25.5 & 20.3 & 11.9 & 5.3 & 1.3 & 0.1 & 0.0 \\
\hline \multicolumn{11}{|l|}{ Obligations to the Fund from existing and } \\
\hline $\begin{array}{l}\text { prospective Fund credit 3/ } \\
\text { In percent of quota }\end{array}$ & 23.3 & 22.5 & 23.0 & 52.6 & 175.0 & 260.8 & 226.0 & 138.7 & 40.0 & 4.2 \\
\hline In percent of quota & 15.5 & 15.0 & 15.3 & 35.0 & 116.5 & 173.5 & 150.4 & 92.3 & 26.6 & 2.8 \\
\hline In percent of GDP & 0.3 & 0.3 & 0.3 & 0.6 & 2.0 & 2.7 & 2.2 & 1.2 & 0.3 & 0.0 \\
\hline In percent of exports of goods and nonfactor services & 1.0 & 1.1 & 0.9 & 1.9 & 5.8 & 7.9 & 6.3 & 3.6 & 1.0 & 0.1 \\
\hline In percent of gross reserves & 2.5 & 1.6 & 1.6 & 3.1 & 10.5 & 15.6 & 14.0 & 8.3 & 2.2 & 0.2 \\
\hline In percent of public external debt service & 29.4 & 20.7 & 18.1 & 31.7 & 61.4 & 35.1 & 58.8 & 31.0 & 10.7 & 1.2 \\
\hline
\end{tabular}

Source: Fund staff estimates and projections.

1/ End of period.

2/ Following the Low Income Countries (LIC) reforms, effective January 7 2010, the PRGF arrangements were renamed Extended Credit Facility (ECF) arrangements.

3/ Repayment schedule based on repurchase obligations and GRA charges. 
Table 9. Georgia: Schedule of Prospective Reviews and Purchases 1/

\begin{tabular}{|c|c|c|c|}
\hline \multirow[t]{2}{*}{ Availability Date } & \multirow[t]{2}{*}{ Condition } & \multicolumn{2}{|c|}{ Available Purchases } \\
\hline & & (In millions of SDR) & (In percent of quota) \\
\hline $15-$ Sep-08 & & 161.7 & 107.6 \\
\hline 15-Dec-08 & ormance criteria and other relevant performance criteria $2 /$ & 63.1 & 42.0 \\
\hline 23-Mar-09 & erformance criteria and other relevant performance criteria $2 /$ & 63.1 & 42.0 \\
\hline 6-Aug-09 & ce criteria and other relevant performance criteria & 94.6 & 62.9 \\
\hline 15-Nov-09 & rformance criteria and other relevant performance criteria & 47.3 & 31.5 \\
\hline 15-Feb-10 & rmance criteria and other relevant performance criteria & 97.3 & 64.7 \\
\hline 9-Jul-10 & cee criteria and other relevant performance criteria & 50.0 & 33.3 \\
\hline $15-N o v-10$ & mber 2010 performance criteria and other relevant performance criteria & 100.0 & 66.5 \\
\hline 15-May-11 & ance criteria and other relevant performance criteria & 70.0 & 46.6 \\
\hline Total available & & 747.1 & 497.1 \\
\hline
\end{tabular}

1/ Reflects the augmentation of access by SDR270 million and the extended arrangement through June 2011.

2/ As the authorities did not draw the purchase that became available at the time of the first review, SDR 126.2 million were available and purchased at the second review. 
Table 10. Georgia: External Financing Requirements and Sources, 2008-15

(In millions of U.S. dollars)

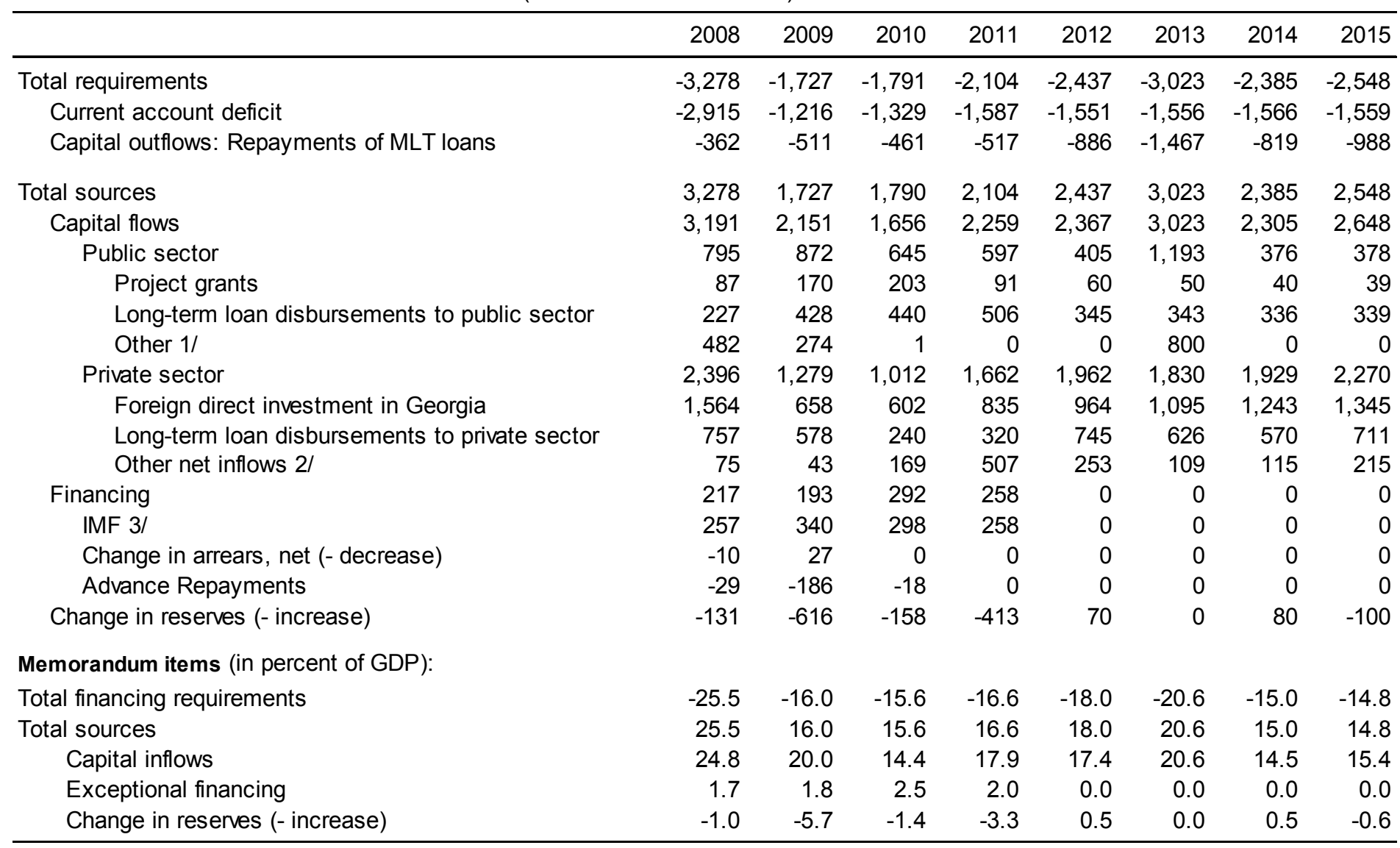

Sources: Georgian Statistics Department; National Bank of Georgia; and Fund staff estimates.

$1 /$ Including the receipts and the repayment of the Eurobond-2013.

2/ Including errors and omissions.

3/ ECF (formerly known as PRGF) disbursements in 2006 and 2007, SBA purchases from 2008 on, including augmentation in 2010-11. 
Table 11. Georgia: Public External Debt, 2008-09

\begin{tabular}{lrrrrrr}
\hline & Dec-08 & Jun-09 & Dec-09 & Dec-08 & Jun-09 & Dec-09 \\
\hline & \multicolumn{2}{c}{ (In millions of U.S. dollars) } & (In percent of GDP) \\
\cline { 2 - 7 } & 2,691 & 2,925 & 3,382 & 20.9 & 27.2 & 31.4 \\
Total & 1,648 & 1,879 & 2,321 & 12.8 & 17.4 & 21.6 \\
Multilateral & 988 & 1,016 & 1,252 & 7.7 & 9.4 & 11.6 \\
WB - IDA & 465 & 647 & 786 & 3.6 & 6.0 & 7.3 \\
IMF & 195 & 216 & 282 & 1.5 & 2.0 & 2.6 \\
Other & 535 & 538 & 560 & 4.2 & 5.0 & 5.2 \\
Bilateral & 446 & 412 & 466 & 3.5 & 3.8 & 4.3 \\
Paris Club & 89 & 127 & 94 & 0.7 & 1.2 & 0.9 \\
$\quad$ Non-Paris Club & & & & & & \\
Commercial & 508 & 508 & 501 & 3.9 & 4.7 & 4.7 \\
\hline
\end{tabular}

Source: Ministry of Finance of Georgia. 
Table 12. Georgia: Private External Debt, 2008-09

\begin{tabular}{|c|c|c|c|c|c|c|c|c|c|c|}
\hline & Dec-08 & Mar-09 & Jun-09 & Sep-09 & Dec-09 & Dec-08 & Mar-09 & Jun-09 & Sep-09 & Dec-09 \\
\hline & \multicolumn{5}{|c|}{ (In millions of U.S. dollars) } & \multicolumn{5}{|c|}{ (In percent of GDP) } \\
\hline Total Private debt $1 /$ & 2,974 & 2,830 & 2,763 & 2,772 & 2,873 & 23.1 & 22.0 & 21.5 & 21.5 & 22.3 \\
\hline Banks & 1,875 & 1,737 & 1,621 & 1,558 & 1,503 & 14.6 & 13.5 & 12.6 & 12.1 & 11.7 \\
\hline Short-term & 566 & 404 & 390 & 370 & 354 & 4.4 & 3.1 & 3.0 & 2.9 & 2.7 \\
\hline Of which: Loans & 355 & 214 & 200 & 140 & 104 & 2.8 & 1.7 & 1.6 & 1.1 & 0.8 \\
\hline Of which: Currency and deposits 2/ & 209 & 187 & 186 & 229 & 250 & 1.6 & 1.5 & 1.4 & 1.8 & 1.9 \\
\hline Long-term & 1,309 & 1,333 & 1,231 & 1,188 & 1,149 & 10.2 & 10.4 & 9.6 & 9.2 & 8.9 \\
\hline Of which: Loans & 1,309 & 1,333 & 1,231 & 1,188 & 1,149 & 10.2 & 10.4 & 9.6 & 9.2 & 8.9 \\
\hline Other Sectors & 1,099 & 1,094 & 1,142 & 1,214 & 1,370 & 8.5 & 8.5 & 8.9 & 9.4 & 10.6 \\
\hline Short-term & 390 & 366 & 395 & 442 & 491 & 3.0 & 2.8 & 3.1 & 3.4 & 3.8 \\
\hline Of which: Trade credits & 324 & 292 & 315 & 325 & 373 & 2.5 & 2.3 & 2.4 & 2.5 & 2.9 \\
\hline Long-term & 709 & 727 & 747 & 772 & 879 & 5.5 & 5.7 & 5.8 & 6.0 & 6.8 \\
\hline Of which: Loans & 709 & 727 & 747 & 772 & 879 & 5.5 & 5.7 & 5.8 & 6.0 & 6.8 \\
\hline Direct Investment: Intercompany Lending & 2,102 & 2,108 & 2,148 & 2,174 & 2,139 & 16.3 & 16.4 & 16.7 & 16.9 & 16.6 \\
\hline
\end{tabular}

Source: National Bank of Georgia.

1/ Excluding intercompany debt from foreign direct investors.

2/ In line with the recommendations of the Debt Statistics Manual that all currency and deposits be included in the short-term category unless detailed information is available to make short-term/long-term attribution. 
Table 13a. Georgia: External Debt Sustainability Framework, Baseline Scenario, 2007-2030 1/ (In percent of GDP, unless otherwise indicated)

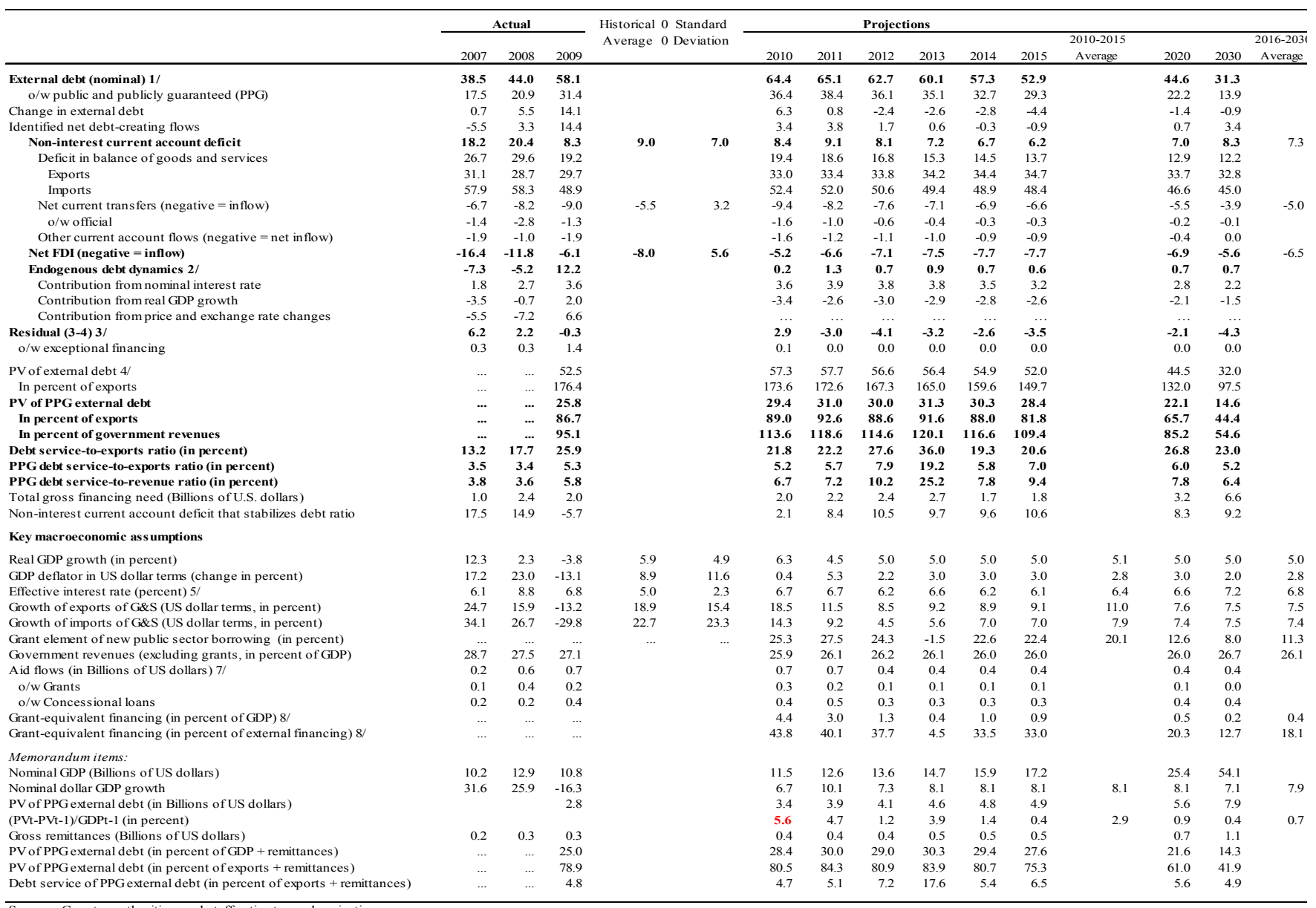

1/ Includes both public and private sector external debt.
$2 /$ Derived as $[\mathrm{r}-\mathrm{g}-\rho(1+\mathrm{g}) /(1+\mathrm{g}+\rho+\mathrm{g} \rho)$ times previous period debt ratio, with $\mathrm{r}=$ nominal interest rate; $\mathrm{g}=$ real GDP growth rate, and $\rho=$ growth rate of GDP deflator in U.S. dollar terms.

3/ Includes exceptional financing (i.e., changes in arrears and debt relief); changes in gross foreign assets; and valuation adjustments. For projections also includes contribution from price and exchange rate changes.

5/ Current-year interest paments divided by previous period debt stue,

6/ Historical averages and standard deviations are generally derived over the past 10 years, subject to data availability

$7 /$ Defined as grants, concessional loans, and debt relief.

CInternational Monetary Fund. Not for Redistribution 
Table 13b.Georgia: Sensitivity Analysis for Key Indicators of Public and Publicly Guaranteed External Debt, 2010-2030 (In percent)

\begin{tabular}{|c|c|c|c|c|c|c|c|c|}
\hline & \multicolumn{8}{|c|}{ Projections } \\
\hline & 2010 & 2011 & 2012 & 2013 & 2014 & 2015 & 2020 & 2030 \\
\hline \multicolumn{9}{|c|}{ PV of debt-to GDP ratio } \\
\hline Baseline & 29 & 31 & 30 & 31 & 30 & 28 & 22 & 15 \\
\hline \multicolumn{9}{|l|}{ A. Alternative Scenarios } \\
\hline A1. Key variables at their historical averages in 2010-2030 1/ & 29 & 28 & 24 & 25 & 24 & 22 & 16 & -4 \\
\hline A2. New public sector loans on less favorable terms in 2010-2030 2 & 29 & 32 & 32 & 33 & 33 & 32 & 27 & 23 \\
\hline \multicolumn{9}{|l|}{ B. Bound Tests } \\
\hline B1. Real GDP growth at historical average minus one standard deviation in 2011-2012 & 29 & 32 & 31 & 32 & 31 & 29 & 21 & 14 \\
\hline B2. Export value growth at historical average minus one standard deviation in 2011-2012 3/ & 29 & 33 & 35 & 36 & 34 & 32 & 23 & 13 \\
\hline B3. US dollar GDP deflator at historical average minus one standard deviation in 2011-2012 & 29 & 33 & 33 & 34 & 33 & 30 & 23 & 14 \\
\hline B4. Net non-debt creating flows at historical average minus one standard deviation in 2011-2012 4/ & 29 & 40 & 48 & 48 & 46 & 43 & 30 & 14 \\
\hline B5. Combination of B1-B4 using one-half standard deviation shocks & 29 & 37 & 41 & 42 & 40 & 37 & 27 & 14 \\
\hline B6. One-time 30 percent nominal depreciation relative to the baseline in $20115 /$ & 29 & 43 & 41 & 42 & 40 & 37 & 28 & 18 \\
\hline
\end{tabular}

\section{PV of debt-to-exports ratio}

Baseline

A. Alternative Scenarios

A 1. Key variables at their historical averages in 2010-2030 1/

A2. New public sector loans on less favorable terms in 2010-20302

89

89

B. Bound Tests

B1. Real GDP growth at historical average minus one standard deviation in 2011-2012

B2. Export value growth at historical average minus one standard deviation in 2011-2012 3/

B3. US dollar GDP deflator at historical average minus one standard deviation in 2011-2012

B4. Net non-debt creating flows at historical average minus one standard deviation in 2011-2012 4/

B5. Combination of B1-B4 using one-half standard deviation shocks

B6. One-time 30 percent nominal depreciation relative to the baseline in 20115 /

PV of debt-to-revenue ratio

Baseline

A. Alternative Scenarios

A1. Key variables at their historical averages in 2010-2030 1/

A2. New public sector loans on less favorable terms in 2010-20302

$\begin{array}{rrrrrrrr}114 & 106 & 93 & 95 & 91 & 85 & \mathbf{6 2} & -15 \\ 114 & 124 & 122 & 127 & 127 & 122 & \mathbf{1 0 5} & 85\end{array}$

\section{B. Bound Tests}

B1. Real GDP growth at historical average minus one standard deviation in 2011-2012 B2. Export value growth at historical average minus one standard deviation in 2011-2012 3 / B3. US dollar GDP deflator at historical average minus one standard deviation in 2011-2012 B4. Net non-debt creating flows at historical average minus one standard deviation in 2011-2012 4/ B5. Combination of B1-B4 using one-half standard deviation shocks

B6. One-time 30 percent nominal depreciation relative to the baseline in 2011 5/

$\begin{array}{rrrrrrrr}114 & 121 & 120 & 124 & 120 & 111 & \mathbf{8 2} & 51 \\ 114 & 126 & 134 & 137 & 132 & 123 & \mathbf{8 9} & 49 \\ 114 & 127 & 127 & 131 & 126 & 117 & \mathbf{8 7} & 54 \\ 114 & 153 & 182 & 184 & 177 & 166 & \mathbf{1 1 6} & 53 \\ 114 & 143 & 157 & 160 & 154 & 144 & \mathbf{1 0 2} & 52 \\ 114 & 163 & 156 & 162 & 155 & 144 & \mathbf{1 0 7} & 66\end{array}$


Table 13b.Georgia: Sensitivity Analysis for Key Indicators of Public and Publicly Guaranteed External Debt, 2010-2030 (continued)

(In percent)

Debt service-to-exports ratio

Baseline

A. Alternative Scenarios

A1. Key variables at their historical averages in 2010-2030 1/

A2. New public sector loans on less favorable terms in 2010-20302

\section{B. Bound Tests}

B1. Real GDP growth at historical average minus one standard deviation in 2011-2012

B2. Export value growth at historical average minus one standard deviation in 2011-2012 3/

B3. US dollar GDP deflator at historical average minus one standard deviation in 2011-2012

B4. Net non-debt creat ing flows at historical average minus one standard deviation in 2011-2012 4

B5. Combination of B1-B4 using one-half standard deviation shocks

B6. One-time 30 percent nominal depreciation relative to the baseline in $20115 /$

Debt service-to-revenue ratio

\section{Baseline}

A. Alternative Scenarios

A1. Key variables at their historical averages in 2010-2030

A2. New public sector loans on less favorable terms in 2010-2030 2

\section{B. Bound Tests}

B1. Real GDP growth at historical average minus one standard deviation in 2011-2012

B2. Export value growth at historical average minus one standard deviation in 2011-2012 3 /

B3. US dollar GDP deflator at historical average minus one standard deviation in 2011-2012

B4. Net non-debt cretting flows at historicl avege mins on stand deviation in 2011-2012

B5. Combination of B1-B4 using one-half standard deviation shocks

B6. One-time 30 percent nominal depreciation relative to the baseline in $20115 /$

Memorandum item:

Grant element assumed on residual financing (i.e., financing required above baseline) 6/

列

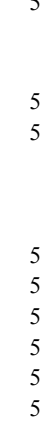

6

19

Sources: Country authorities; and staff estimates and projections.

1/ Variables include real GDP growth, growth of GDP deflator (in U.S. dollar terms), non-interest current account in percent of GDP, and non-debt creating flows.

2/ Assumes that the interest rate on new borrowing is by 2 percentage points higher than in the baseline., while grace and maturity periods are the same as in the baseline

3/ Exports values are assumed to remain permanently at the lower level, but the current account as a share of GDP is assumed to return to its baseline level after the shock (implicit/ an offsetting adjustment in import levels).

4 / Includes official and private transfers and FDI.

5/ Depreciation is defined as percentage decline in dollar/local currency rate, such that it never exceeds 100 percent.

6/ Applies to all stress scenarios except for A2 (less favorable financing) in which the terms on all new financing are as specified in footnote 2 . 
Table 14a.Georgia: Public Sector Debt Sustainability Framework, Baseline Scenario, 2007-2030

(In percent of GDP, unless otherwise indicated)

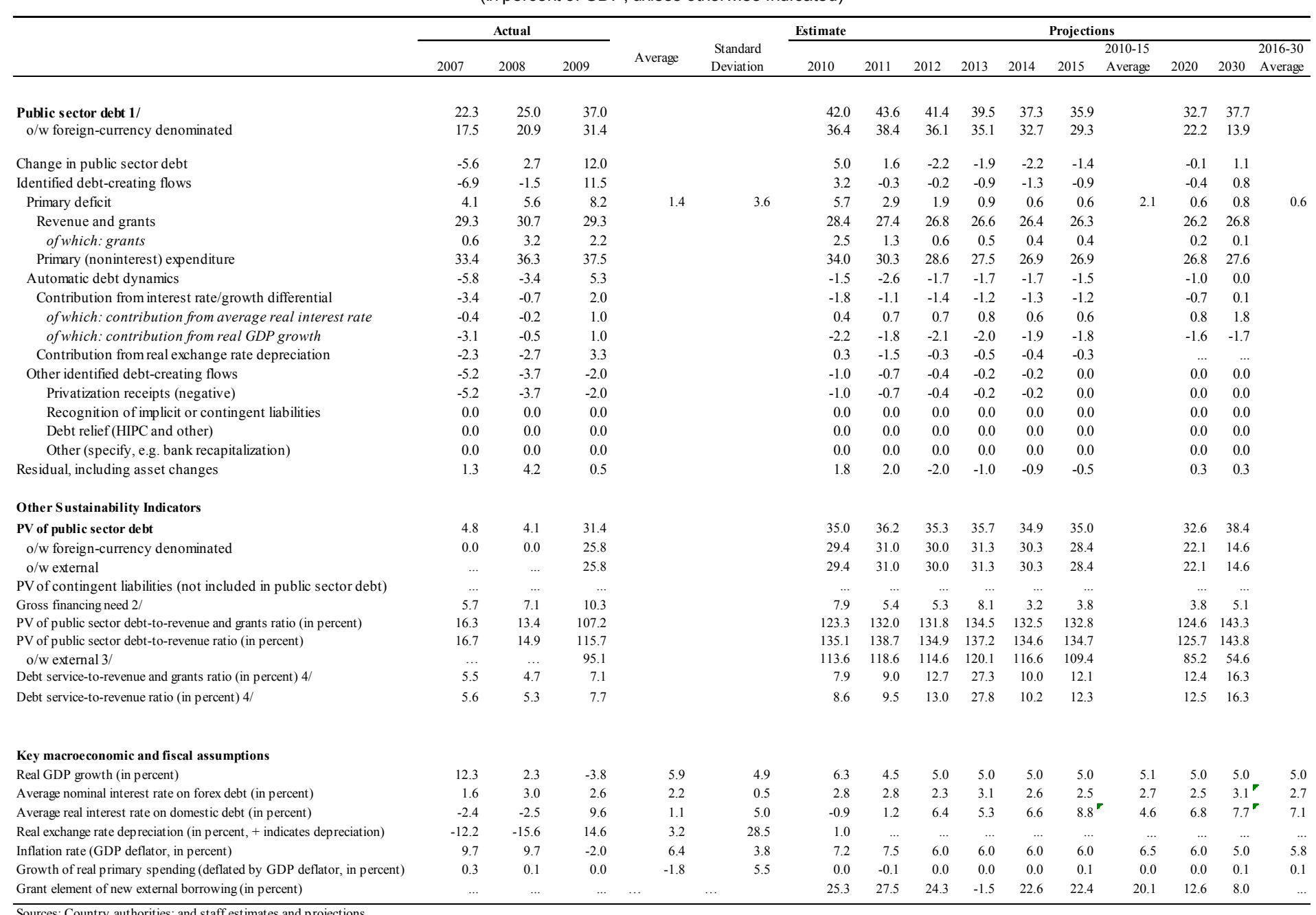

Sources: Country authorities; and staff estimates and projections.

$1 /$ [ndicate coverage of public sector, e.g, general government or nonfinancial public sector. Also whether net or gross debt is used.]

2/ Gross financing need is defined as the primary deficit plus debt service plus the stock of short-term debt at the end of the last period.

$3 /$ Revenues excluding grants.

4/ Debt service is defined as the sum of interest and amortization of medium and long-term debt.

$5 /$ Historical averages and standard deviations are generally derived over the past 10 years, subject to data availability. 
Table 14b.Georgia: Sensitivity Analysis for Key Indicators of Public Debt 2010-2030

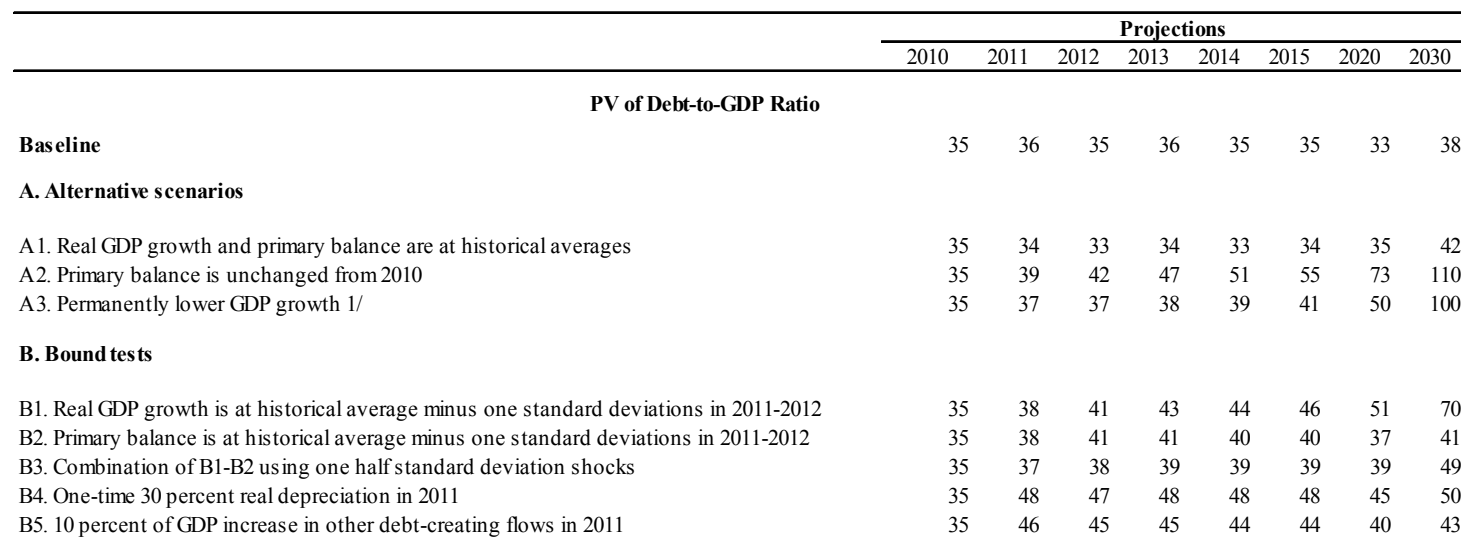

\section{PV of Debt-to-Revenue Ratio 2/}

Baseline

A. Alternative scenarios

A1. Real GDP growth and primary balance are at historical averages

A2. Primary balance is unchanged from 2010

A3. Permanently lower GDP growth $1 /$

$\begin{array}{llllllll}123 & 125 & 122 & 127 & 127 & 130 & 133 & 158 \\ 123 & 142 & 156 & 176 & 192 & 210 & 280 & 411\end{array}$

B. Bound tes ts

B1. Real GDP growth is at historical average minus one standard deviations in 2011-2012 B2. Primary balance is at historical average minus one standard deviations in 2011-2012

B3. Combination of B1-B2 using one half standard deviation shocks

B4. One-time 30 percent real depreciation in 2011

B5. 10 percent of GDP increase in other debt-creating flows in 2011

Debt Service-to-Revenue Ratio 2/

Bas eline

A. Alternative scenarios

A1. Real GDP growth and primary balance are at historical averages

A2. Primary balance is unchanged from 2010

A3. Permanently lower GDP growth $1 /$

$\begin{array}{rrrrrrrr}8 & 9 & 12 & 26 & 9 & 12 & 12 & 16 \\ 8 & 9 & 13 & 28 & 12 & 15 & 18 & 32 \\ 8 & 9 & 13 & 28 & 11 & 13 & 15 & 29\end{array}$

\section{B. Bound tests}

B1. Real GDP growth is at historical average minus one standard deviations in 2011-2012

B2. Primary balance is at historical average minus one standard deviations in 2011-2012

B3. Combination of B1-B2 using one half standard deviation shocks

B4. One-time 30 percent real depreciation in 2011

B5. 10 percent of GDP increase in other debt-creating flows in 2011

$\begin{array}{llllllll}123 & 140 & 152 & 163 & 167 & 174 & 195 & 261 \\ 123 & 140 & 152 & 154 & 151 & 151 & 140 & 154 \\ 123 & 135 & 141 & 147 & 147 & 149 & 150 & 184 \\ 123 & 176 & 177 & 182 & 181 & 182 & 170 & 188 \\ 123 & 168 & 168 & 170 & 167 & 166 & 152 & 162\end{array}$

Sources: Country authorities; and staff estimates and projections.

1/ Assumes that real GDP growth is at baseline minus one standard deviation divided by the square root of the length of the projection period.

2/ Revenues are defined inclusive of grants. 
Figure 1a. Georgia: Indicators of Public and Publicly Guaranteed External Debt under Alternatives Scenarios, 2010-2030 1/
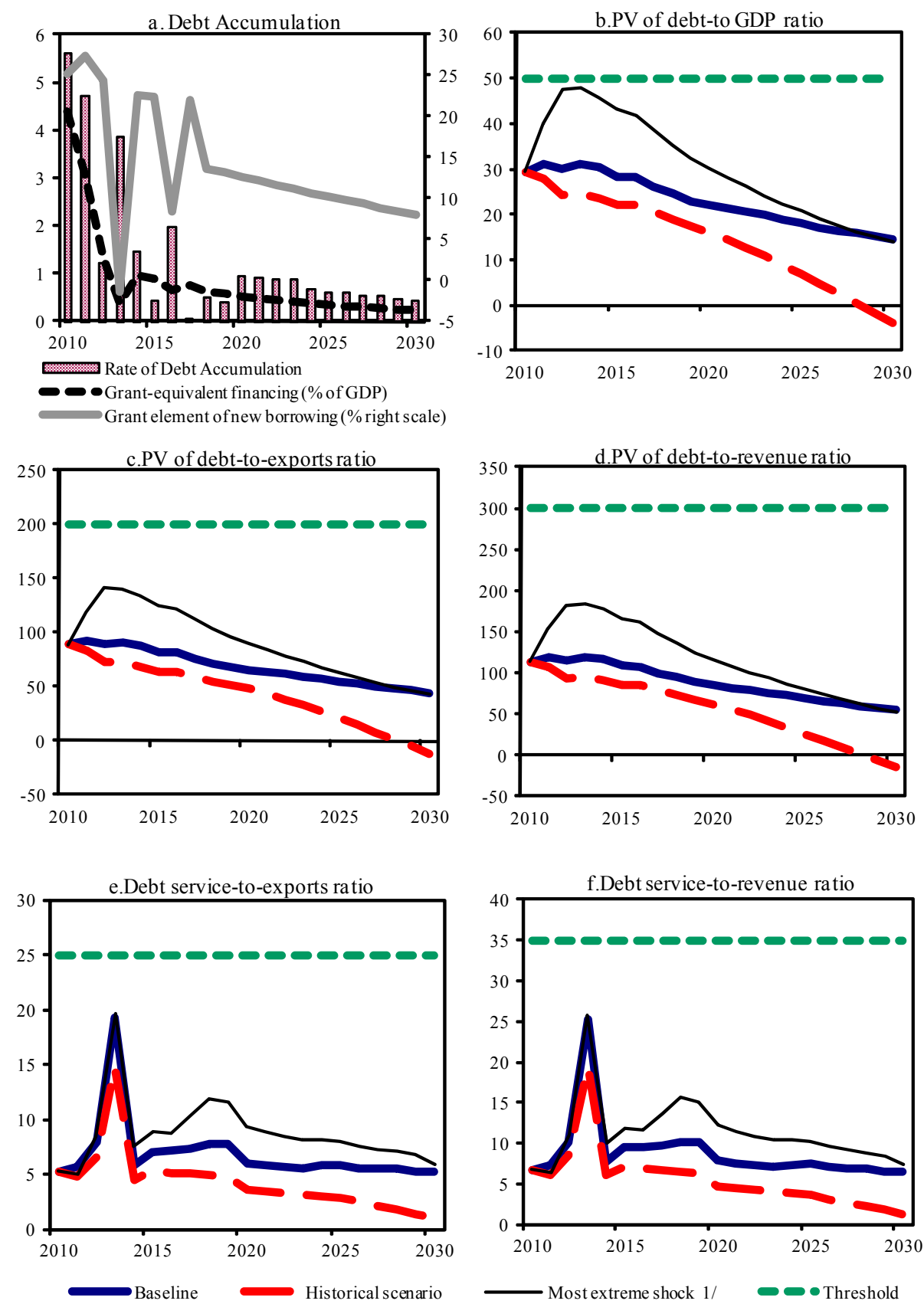

Sources: Country authorities; and staff estimates and projections.

$1 /$ The most extreme stress test is the test that yields the highest ratio in 2020. In figure b. it corresponds to a Non-debt flows shock; in c. to a Non-debt flows shock; in d. to a Non-debt flows shock; in e. to a Non-debt flows shock and in figure f. to a Non-debt flows shock 
Figure 1b.Georgia: Indicators of Public Debt Under Alternative Scenarios, 2010-2030
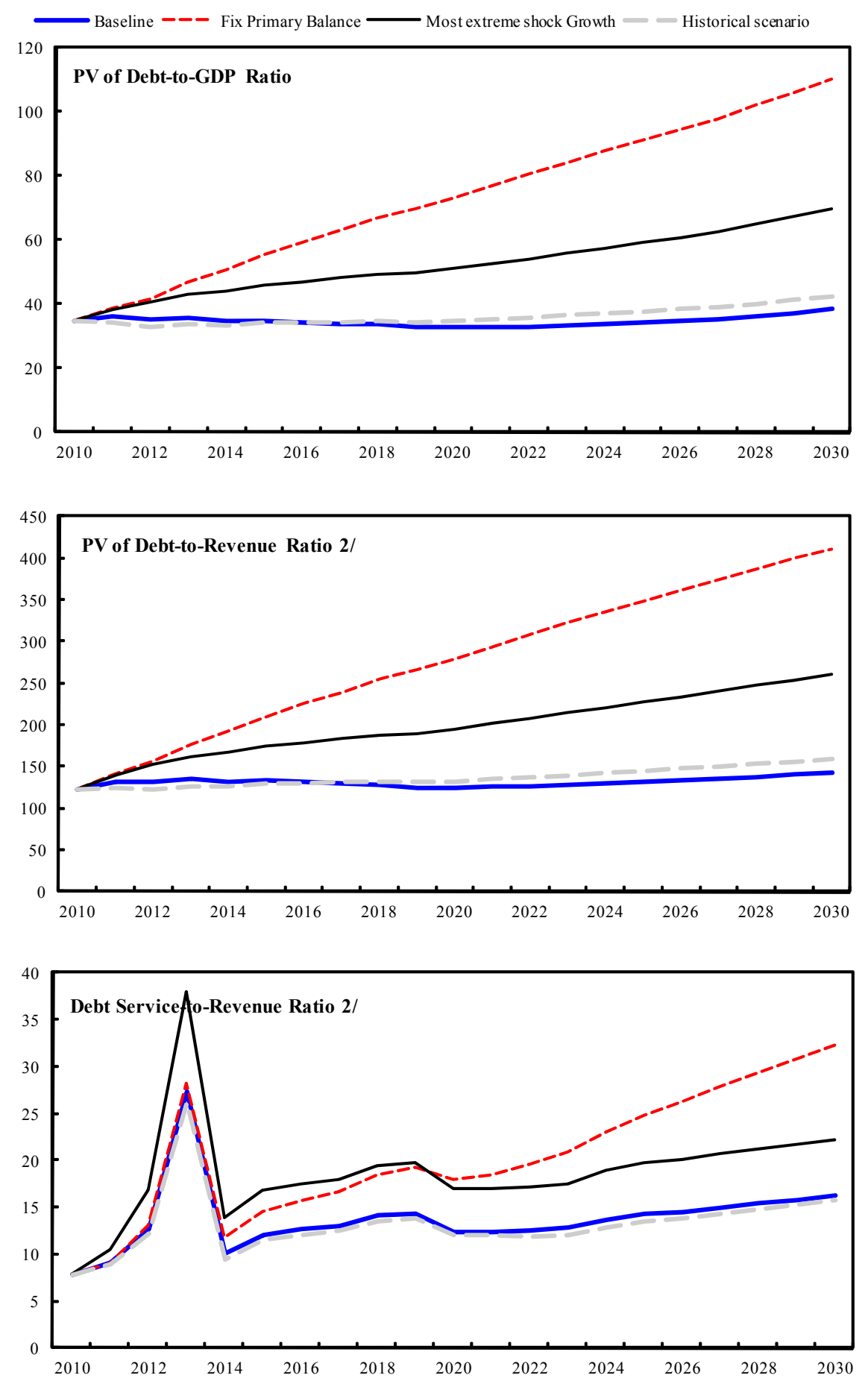

Sources: Country authorities; and staff estimates and projections.

1/ The most extreme stress test is the test that yields the highest ratio in 2020.

2/ Revenues are defined inclusive of grants. 


\section{ATTACHMENT I. GEORGIA: LETTER OF INTENT}

December 22, 2010

Mr. Dominique Strauss-Kahn

Managing Director

International Monetary Fund

Washington, D.C.

Dear Mr. Strauss-Kahn:

1. In September 2008, the International Monetary Fund (IMF) approved a Stand-By Arrangement (SBA) for Georgia, which was further augmented in August 2009. On July 9, 2010 the IMF's Executive Board completed the sixth review of the SBA allowing for an immediate purchase of an amount equivalent to SDR 50 million. We are grateful for the assistance which the IMF provides to Georgia.

2. This letter of intent describes the economic policies that we plan to implement during 2010 and 2011. As always, we are committed to policies that will maintain macroeconomic stability, protect the economy from shocks associated with the global economic crisis and facilitate the process of macroeconomic adjustment. We, of course, remain committed to implementing the measures contained in previous letters of intent, i.e. those dated September 9, 2008, November 28, 2008, March 10, 2009, July 30, 2009, November 25, 2009, February 25, 2010, and June 24, 2010.

\section{Recent Economic Developments}

\section{Macroeconomic developments}

3. From the beginning of 2010 economy started to recover. In the first half of 2010 real growth of the economy reached 6.5 percent. Significant growth was achieved in manufacturing $(19.6 \%)$, transport $(14.6 \%)$, trade $(12.9 \%)$, and construction $(12.5 \%)$.

4. Balance of payments data for the first half of 2010 show that exports of goods and services increased year-on-year by 25.3 percent and imports of goods and services increased by 13.7 percent; FDI inflows declined by 6.9 percent year-on-year. The current account deficit dropped to 9.5 percent of GDP in the first half of 2010, showing significant improvement relative to the same period of the previous years. In 2009, the current account deficit was 11.3 percent of GDP and 22.7 percent in 2008. In the second quarter of 2010, FDI increased compared to Q1, 2010.

5. As a result of recent developments in global commodity markets, particularly soaring wheat prices, prices of several key CPI basket components have also increased, which pushed inflation rate up to $10.5 \%$ year-to-year in November, 2010. Higher inflation figure, 
especially for food products lead to the increased inflation expectations. In order to bring inflation back to target NBG has tightened monetary policy for the last four Monetary Policy Committee (MPC) meetings, increasing the refinancing rate from 5 to 7.5 percent. As part of the tightening policy, NBG also extended the coverage of reserve requirements to external borrowing of commercial banks.

6. Fiscal performance in the first three quarters of 2010 has been stronger than anticipated. Tax collection in Q1-3 2010 increased by 17.0 percent y-o-y in nominal terms (excluding one-off payments). Expenditures in the first three quarters of 2010 were contained at GEL 4988.0 million (general government, including capital expenditures), or 3 percent higher than in the same period of 2009 and in line with the program target. In all, the Q1-3 fiscal deficit reached 3.8 percent of the projected annual GDP, which is consistent with the program target.

7. Consistent with our commitment to increase exchange rate flexibility, starting from May 25, 2009, the NBG foreign exchange interventions are conducted only through the foreign exchange auctions. Less frequent interventions have increased flexibility of the Lari. During the first half of the year, the Lari currency depreciated against the U.S. dollar by $11.5 \%$, and has since appreciated by $6.4 \%$.

8. In order to cover part of the FX financing gap of the private sector, in the first half of the year NBG sold at the FX market \$321 million. Since June demand for FX has weakened and NBG has intervened occasionally to buy foreign exchange in the market. Since September exchange rate started to appreciate mainly due to mix of factors, including increase in non-resident FX deposits and market expectation. The depreciation of US Dollar vis-a-vis other major currencies contributed to its depreciation against Lari as well.

9. The banking sector continued its positive performance in the third quarter of 2010 . Commercial banks' net profits in the third quarter equaled GEL 58 million. In October Commercial banks' net profits increased by GEL 26 million. Starting from May 2009, the volume of deposits has been growing steadily, posting a 44.9 percent annual growth in lari terms by end-October 2010. Bank lending to the economy has picked up, and credit to the economy has increased by 10.8 percent (6.5 percent excluding FX valuation effects) annually as of end-October. The major part of the increase in credit is attributed to lending in domestic currency. Banking sector remains highly capitalized; with the average capital adequacy ratio of 18.5 at end-October 2010. Since October NBG increased minimum liquidity ratio from $20 \%$ to $30 \%$, to the level that existed before the crisis.

\section{Structural reforms}

10. To increase efficiency of monetary policy NBG has made a number of reforms, that include raising reserve requirements in local currency, activation of standing facilities, more active use of refinancing instrument and widening the base for reserve requirement by including borrowed funds by commercial banks in FX. NBG started to provide commercial 
banks with guaranteed access to refinancing loans against collateral at the interest linked to the NBG's key policy rate. The collateral base for refinancing loans is extended to include international bank guarantees and long term local currency loans.

11. We continue to improve the efficiency and effectiveness of public finances. The Ministry of Finance is broadly on track in implementing the Public Finance Management Reform Policy Vision 2009-2013, which we view as an important prerequisite to ensuring transparency, discipline, efficiency and accountability in the public finance area. The Reform Action Plan for 2010 is being successfully implemented. Consistently with the new budget code, by end-July 2010 cabinet endorsed the medium-term expenditure framework (Basic Data and Directions) that included expenditure ceilings applicable to the 2011 budget (structural benchmark under the program). Also, in October 2010 the cabinet endorsed guidelines for pilot Ministries to introduce a programmatic approach to budgeting, in line with the recommendations of the technical assistance from the IMF's Fiscal Affairs Department (structural benchmark).

12. In pursuance of our reforms aimed at fostering a culture of compliance and streamlining tax and customs administration procedures, we seek achievement of further cost-efficiency and effectiveness gains within the Revenue Service of the Ministry of Finance, with a view to enhance business-friendliness of tax and customs processes and legislation and thus to promote private sector-led growth. In 2010, we have progressed significantly in establishing electronic information exchange system between banks and the Revenues Service, establishing a customs post-clearance audit, integrating all taxes into the e-filing system, introducing advance ruling in the customs and tax field, establishing the commodity expertise within the Revenue Service and the institute of personal tax agent, introducing electronic VAT invoices and one stop shop at the land customs crossing point for commercial vehicles, elaborating procedures manuals for Revenue Service officers, introducing web-based e-services, web applications, video help and centralized consultative correspondence via e-mails. The implementation of these reforms has enhanced efficiency and effectiveness in the use of public financial resources and shall contribute to the overall resilience of the economy both now and over the medium term.

\section{Macroeconomic Outlook and Policies for the remainder of 2010 and for 2011}

\section{Macroeconomic outlook and risks}

13. Our major macroeconomic challenge continues to be further increase in the pace of economic growth while promoting balance of payments adjustment. This will, of course, require increase of private capital inflows and domestic lending in support of investment projects. Our efforts to enhance macroeconomic stability concentrate on intensifying economic reforms, and achieving a sustainable fiscal and external balance as quickly as possible. 
14. Economic growth remains strong, in the first two quarters of 2010 economy increased by 3.9 and 8.7 percent respectively. Overall in the 2010 real GDP growth is projected at $5.5-$ 6.0 percent per annum. Growth is expected to be strong in 2011, at 4.5 percent.

15. The current account deficit for 2010 is expected to be around 11.6 percent of GDP. Exports and imports of goods and services are projected to increase by 18.5 percent and 14.3 percent, respectively. Worker remittances are expected to increase by around 26.9 percent for the year. We expect the recovery in private capital inflows to accelerate in the second half of 2010. Conservatively, we project FDI inflows of about US\$603 million in 2010 , slightly less than in 2009. Overall, gross reserves in 2010 are expected to increase by about US\$92 million. In 2011, the current account deficit would increase to 12.6 percent of GDP, as the slowdown in export growth (which would grow by 11.5 percent) would be more marked than that of imports (which would grow by 9.2 percent). Capital flows would increase substantially, contributing to a further increase in gross international reserves of about $\$ 413$ million.

16. There are substantial risks to this outlook, notably related to the uncertainty surrounding future capital inflows. In particular, a failure of FDI to resume could lower growth and reopen an external financing gap. On the upside, based on recent inflation and appreciation pressures, there are also risks of overheating, which could be further fueled in the future by stronger-than-expected capital inflows.

\section{Policies}

17. We consider that sound fiscal position is critical for the sustainability of the recovery and also to preserve the stability of Georgia's external accounts. We are therefore committed to the deficit reduction. Based on further expenditure containment, an expected recovery of tax revenues owing to sustained GDP growth as well as the revenue measures taken in 2010 and 2011, we are committed to steady reductions in the deficit to 2-3 percent of GDP by 2013. Moreover, in order to increase policy flexibility in the event of adverse economic developments, we have introduced an escape clause in the constitutional amendment requiring that tax increases be subject to referendums. The conditions under which the referendum requirement would be suspended will be defined by the Economic Freedom Act, which will be resubmitted to parliament in 2011. The constitutional amendment, which was adopted on December 15, 2010, will only come into effect once the Economic Freedom Act is also approved.

18. In 2010, spending is expected to be in line with what was agreed at the time of the sixth review, except for the on-lending operation which is described below, in $\{28$. Revenues are likely to be lower than projected, reflecting a shortfall in budget-support grants of GEL 56 million. The shortfall is due to the late disbursement of budget grants, which we now expect to come in 2011. Tax revenue projections remain unchanged, but other domestic revenues could make up for the shortfall in budget grants. As a result of these two factors 
(on-lending operation and shortfall in budget grants), the deficit is anticipated to be at most GEL 156 million higher than envisaged at the time of the sixth review (GEL 1,397 million, compared with GEL 1,241 million). However, the deficit would decline significantly in 2010, to 6.8 percent of GDP from 9.2 percent of GDP in 2009.

19. In 2011, we will pursue our fiscal consolidation efforts so as to reduce demand pressures in the economy, while facilitating the return to international capital markets through strengthening medium-term fiscal sustainability. Consistent with these objectives, the fiscal deficit will be reduced further to 4.3 percent of GDP. This reduction would reflect measures aimed at curbing spending, such as restraining public sector wage bill in nominal terms, reduction of defense budget, stable education spending in nominal terms, no increase in pensions and no change in thresholds of social assistance schemes. The tax-to-GDP ratio is projected to increase relative to 2010 owing to the full year effect of the measures taken in 2010 (excises on telecommunications and certain beverages), as well as the new measures coming into effect in 2011(harmonization of personal income tax rates and VAT on public health services).

20. Monetary policy will aim at bringing back year-on-year inflation towards our 6percent target by end-2011, while fostering investors' confidence through increases in gross and net international reserves. More specifically, we consider that credit growth of 15 to 20 percent is consistent with noninflationary growth. To meet these objectives, the NBG has already raised the policy rates and considers increasing reserve requirements on foreign exchange deposits and external borrowing. The latter should also contribute to strengthening the ongoing dedollarization process. The need for additional tightening will be assessed based on inflation, credit, and foreign exchange market developments.

21. The exchange rate policy will remain flexible. Within the aforementioned limit, the NBG will intervene only to smooth extreme volatility, to counter speculative pressures and if too fast and too large depreciation threatens financial stability. Intervention will also be constrained by our objective to increase net international reserves in 2011 to around $\$ 885$ million by end-2011. Should persistent appreciation pressures materialize, we will address them through a tightening of the fiscal stance. Should external developments prove more favorable than currently projected, we stand ready to raise the NIR targets for future reviews, so as to strengthen our exit strategy from official balance of payments support.

22. To further strengthen regulatory disincentive for lending in foreign currency and taking into account recent rapid recovery, the NBG is considering increasing the weight for loans denominated in foreign currency in risk-weighted assets from 1.5 to 1.75. In line with changes in legislation, which enable the supervisor to conduct risk-based supervision, a reorganization process is under way to enable the NBG to use more effectively its resources for risk based supervision. The move toward a risk based framework is done gradually, to minimize regulatory risk for the industry and enable smooth transition towards the new regulatory framework. 
23. To facilitate reduction of information costs and promote the cross product and cross bank comparability of the financial products NBG plans to implement consumer financial protection framework in 2011. In line with short term objectives, Georgian banks will be obliged to standardize retail contracts in more understandable way, disclosing all necessary information with new features like effective annual percentage rate and other vital information for informed decision making. A special unit is planned to be created inside NBG that will be in charge of monitoring and strengthening consumer protection.

\section{Structural reforms}

24. In order to enhance the safety and efficiency of the international reserves management process, the NBG is implementing a new portfolio management system. The system will cover front-middle-back office and accounting functionality based on Straight Through Processing (STP) principles. The system will be IFRS compliant and will allow NBG to introduce new, more sophisticated financial instruments and investment techniques in its reserves management process. The new system will help NBG bring its reserves management procedures in line with international best practices. NBG has signed the contract on system supply and implementation with WallstreetSystems, leading portfolio management system supplier who has over 30 central banks clients around the world. The system is expected to become fully operational by end of April 2011.

25. To bring our official statistics in line with international standards, we improved legal framework and reorganized the former State Department of Statistics (new title-Geostat). New Law on State Statistics strengthens the independence of the Geostat and ensures the sustainable production of official statistics. On May 17, 2010, we subscribed to the IMF's Special Data Dissemination Standard (SDDS), with a view to enhancing the availability of timely and comprehensive statistics provided to the public.

26. Based on the higher than projected budget support disbursements from IFIs in 2010, we reduced the Government's use of IMF financing for the budget. Accordingly, the purchase that was made upon completion of the sixth review was the last purchase for budget support in 2010.

27. We have implemented the recommendations provided in the recent update of the Safeguards Assessment Report. In particular:

- The new Audit Committee Charter was elaborated based on the best international practice.

- The Audit Committee composition was modified and includes only non-executive members of the Board.

- The oversight function of the Audit Committee was strengthened.

- The assessment of internal audit activities for compliance with the International Standards for Professional Practice of Internal Auditing and The IIA's Code of Ethics was conducted. 
- The Internal Audit Service reviewed operations of the newly implemented core banking system.

The internal audit of the new RTGS and reserve management systems will be carried out following their deployment.

\section{Program Monitoring}

28. We expect all end-December performance criteria under the Stand-By Arrangement to be met, with the exception of the general government deficit and total expenditure targets, owing to the delayed disbursement of budget grants in the amount of GEL 56 million, which we expect to receive in 2011, and the early disbursement by KfW-EBRD-EIB (and onlending by the government) of a GEL 100-million amount under the high voltage power transmission project loan. These will cause deficit and spending overruns of about GEL 156 million (or 0.75 percent of GDP) and GEL 100 million (or 0.5 percent of GDP), respectively, relative to the program targets. Even though the delay in the disbursement of budget grants does not affect the underlying fiscal adjustment commitment, we expect that other revenues will compensate in large part for this shortfall in 2010. Similarly, we do not consider that the overruns related to the early disbursement of KfW-EBRD-EIB's project loan, and related onlending by the government, affect the underlying fiscal adjustment. Moreover this operation has a zero net expected impact on public finances, since it is equivalent to guaranteeing a loan to a commercially viable public enterprise. As such we do not consider it necessary or appropriate to adjust the government's fiscal position in response to changes in the disbursement schedule of this loan. To avoid such problems going forward, we request that the fiscal deficit and general government expenditure targets be adjusted for any changes in the timing of disbursements under this loan relative to our expectations as reflected in the program deficit and expenditure ceilings.

29. Therefore, based on our performance under the program, we request waivers of nonobservance of the end-December 2010 PCs on the cash deficit of the general government and on the general government expenditures, a rephasing of purchases, the establishment of end-March 2011 PCs, and the completion of the seventh and eighth Reviews. We will maintain our usual close policy dialogue with the Fund and are ready to take additional measures as appropriate to ensure that we meet program objectives.

30. The attached Table 1 establishes end-March 2011 PCs on the fiscal deficit, NIR, NDA, and total government expenditures, as well as an end-March 2011 indicative target on external public debt. We request that the ninth review be based on end-March 2011 performance criteria and be scheduled for completion by June 14, 2011.

31. We authorize the IMF to publish this Letter of Intent and its attachments as well as the accompanying staff report. 
Sincerely yours,

$/ \mathrm{s} /$

Nika Gilauri

Prime Minister of Georgia
$/ \mathrm{s} /$

Kakha Baindurashvili

Minister of Finance

$/ \mathrm{s} /$

Giorgi Kadagidze

President of the National Bank of Georgia 
Table 1. Georgia: Quantitative Performance Criteria (PC) and Indicative Targets, 2010-11

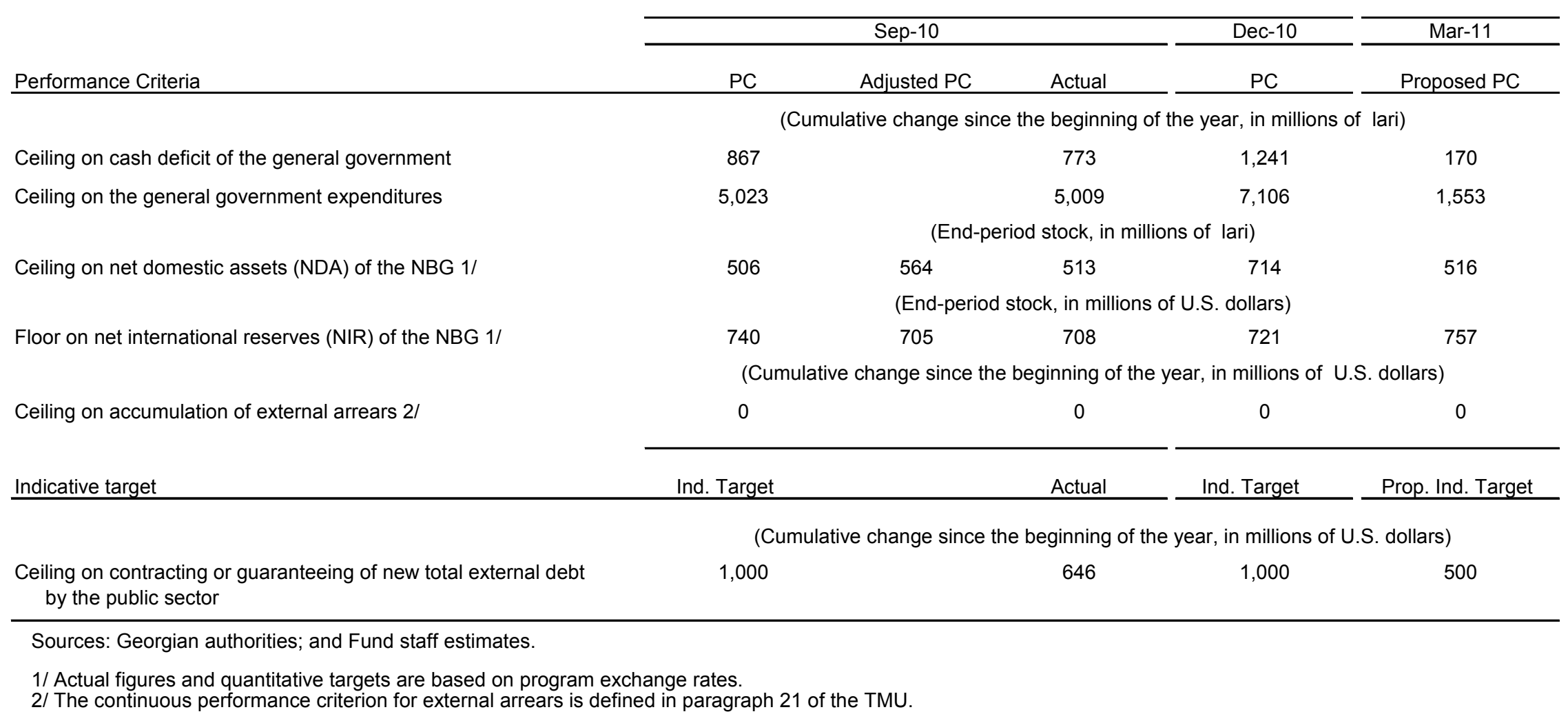


Table 2. Georgia: Structural Benchmarks

\section{Action}

FSA and NBG to sign and implement a memorandum of understanding to strengthen cooperation.

NBG to introduce revised LOLR facility.

Submission to parliament of a state budget for 2009 with an overall fiscal deficit of no more than $33 / 4$ percent of projected GDP (subject to an adjustor of at most 3 percent of GDP as set out in the TMU).

NBG to develop and publish a liquidity management framework, including the introduction of a refinancing mechanism as the main instrument to provide liquidity.

The NBG, the FSA, and the government to develop a financial stability plan that will contain policy actions to respond to potential situations of stress by defining the roles and responsibilities of the different players-the NBG, the FSA and the government-under each circumstance.

Appointment of the remaining members to the FSA board.
Submission of a new budget code to the cabinet to make the budget preparation process more inclusive, enhance the budget execution monitoring process, and move to performance driven policy by improving strategic planning.

Status report on the implementation of the action plan described in the Financial Stability Plan, including bank-by-bank contingency measures based on stress test results and assurances of support from foreign shareholders.

\author{
Proposed \\ Time Frame
}

End-Oct-08

Structural

Benchmark

Structural

End-Dec-08

End-Dec-08

End-Mar-09

End-Jun-09

End-Jun-09

Structural

Benchmark

End-Jul-09

Type of Conditionality

Status

Performance

Criterion

Observed

Structural

Benchmark

Observed

Not

Structural

Benchmark

observed.

Implemented

with delay

Structural

Performance

Criterion

Observed

Not observed, became redundant with elimination of FSA board

Structural Benchmark

Observed

End-Sep-09

Structural Benchmark

Observed 
Submission to parliament of a state budget for 2010 that: (i) is consistent with the program targets and assumptions, and an overall deficit of no more than 7.3 percent of GDP (program definition); (ii) contains a medium-term fiscal framework consistent with the program's medium-term deficit reduction targets; and (iii) describes the medium-term policies underlying the fiscal deficit objectives through 2013.

Cabinet approval of a new medium-term expenditure framework (Basic Data and Directions) that includes expenditure ceilings applicable to the 2011 budget.

Cabinet approval of guidelines for pilot ministries to introduce a programmatic approach to budgeting, in line with the recommendations of the IMF technical assistance report "Georgia-Advancing Program Budgeting," by D. Radev, S. Flynn, L. Eyraud, and S. Gurr, May 2010.

\section{October 1, $2009 \quad \begin{gathered}\text { Structural } \\ \text { Benchmark }\end{gathered}$ Observed}

July 31, $2010 \quad$ Structural

Benchmark

Observed

September 30, $2010 \quad$ Structural

Implemented with delay on October 13. 


\section{ATtACHMENT II. GeORgIA: REVISED TeChNICAL MEMORANDUM OF UNDERSTANDING}

December 22, 2010

1. This memorandum sets out the understandings between the Georgian authorities and the IMF staff regarding the definitions of quantitative performance criteria and indicative targets, as well as respective reporting requirements for the Stand-By Arrangement (SBA). It replaces the technical memorandum of understanding dated June 24, 2010.

2. These performance criteria and indicative targets are reported in Tables 1 attached to the Letter of Intent dated December 22, 2010. The exchange rate for the purposes of the program of the Georgian lari to the U.S. dollar is set at GEL $1.67=\$ 1$. The corresponding cross exchange rates are provided in Table 1.

\section{General Government ANd the Public Sector}

3. Definition: The general government is defined as the central government, local governments, and extra-budgetary funds. The public sector consists of the general government and the National Bank of Georgia (NBG).

4. Supporting material: The Treasury Department of the Ministry of Finance (MOF) will provide to the IMF detailed information on monthly revenues of the general government within two weeks of the end of each month, and monthly expenditures and arrears of the central government within four weeks of the end of each month. In addition, the Treasury will provide, on a daily basis, the cash balances in the accounts of the general government as of the previous business day.

\section{Quantitative Performance Criteria, Indicative Targets, and Continuous Performance Criteria: Definitions and Reporting Standards}

\section{A. Quantitative Performance Criteria and Indicative Targets}

5. The quantitative performance criteria and indicative targets specified in Table 1 attached to the Letter of Intent are:

- a performance criterion (ceiling) on the cash deficit of the general government;

- a performance criterion (ceiling) on the general government expenditures;

- a performance criterion (floor) on net international reserves (NIR) of the NBG;

- a performance criterion (ceiling) on net domestic assets (NDA) of the NBG; 
- a continuous performance criterion (zero ceiling) on the accumulation of external arrears; and

- an indicative target (ceiling) on the contracting and guaranteeing of new total external debt by the public sector.

The performance criteria and the indicative target are monitored quarterly on a cumulative basis from the beginning of the calendar year (with the exception of the NIR and NDA targets, which are monitored in terms of stock), while the continuous performance criterion is monitored on a continuous basis.

\section{B. Ceiling on the Cash Deficit of the General Government}

6. Definition: The cash deficit of the general government will be measured from the financing side at current exchange rates, and will be defined as equal to total financing. Total financing will be defined as the sum of (i) net domestic financing from banks and nonbanks, (ii) net external financing, and (iii) privatization receipts.

- Net domestic financing consists of bank and nonbank net financing to the general government which will be defined as follows:

(i) Net lending (borrowing net of repayments) provided by commercial banks to the general government plus the use of deposits held by the general government at commercial banks. Monitoring of net lending and government accounts will be based on the NBG's monetary survey and Treasury data. The change in cash balances of the local government at commercial banks for budget financing purposes will be monitored based on the "budget of territorial unit" account data provided by the Treasury Department. Any securities issued by the general government and purchased by commercial banks (for example, T-Bills) are also included in domestic financing.

(ii) Net lending (borrowing net of repayments) provided by the NBG to the general government plus the use of deposits of the general government held at the NBG. Monitoring of net lending and government accounts will be based on the Central Bank survey and Treasury data. The change in cash balances of the central government at the NBG for budget financing purposes will be monitored based on the "GEL TSA state budget" account data provided by the Treasury Department. Any securities issued by the general government and purchased by the NBG (for example, T-Bills) are also included in domestic financing.

(iii) Any securities issued by the general government and purchased by the nonbanks (for example, T-Bills or securitized claims on the government sold by the NBG) are also included in domestic financing. 
- Net external financing is defined as the total of loans disbursed to the general government for budget support (including from the IMF), and project financing (capital expenditure and net lending), net change in external arrears, change in the accounts of the general government abroad, minus amortization. Amortization includes all external debt-related payments of principal by the general government.

- $\quad$ Privatization receipts consist of all transfers of monies received by the central and local governments in connection with the sale of central or local government assets. This includes receipts from the sale of shares, the sale of non-financial assets as well as leases and the sale of licenses with duration of 10 years and longer.

\section{Adjustor:}

- The end-March 2011 ceiling on the cash deficit of the general government will be adjusted upward/downward by 100 percent for any excess/shortfall in on-lending by the government of the disbursements of the Black Sea Transmission Network project loans relative to the projected GEL 40 million.

\section{Supporting material:}

- Data on domestic bank and nonbank financing will be provided to the IMF by the NBG and the Treasury Department of the MOF within four weeks after the end of the month.

- Data on external project financing as well as other external borrowing will be provided to the IMF monthly by the Debt Unit at the MOF (specifying projects by creditor) within two weeks of the end of each month.

- $\quad$ Data will be provided at the actual exchange rates.

- Data on privatization receipts of the general government will be provided by the Treasury Department of the MOF to the IMF on a monthly basis within two weeks of the end of each month.

- Data on securitized debt sold by the NBG, including the securities that have been purchased by nonbanks, will be reported by the NBG on a monthly basis within two weeks of the end of each month.

\section{Ceiling on the General Government Expenditures}

9. Definition: General government expenditures comprise all current and capital expenditures as well as net lending: (i) current expenditures comprise compensation of employees, use of goods and services, subsidies, grants, social expenses, other expenses, other account payables and domestic and external interest payments; (ii) capital 
expenditures include projects financed by foreign loans and grants; (iii) net lending is defined as lending by, minus repayments to, the general government.

\section{Adjustor:}

- $\quad$ The end-March 2011 ceiling on the general government expenditures will be adjusted upward/downward by 100 percent for any excess/shortfall in on-lending by the government of the disbursements of the Black Sea Transmission Network project loans relative to the projected GEL 40 million.

11. Supporting material: Data for monitoring expenditures will be derived from the accounts of the general government covered under the ceiling (based on state, local authority, and autonomous republics budgets). The ministry of finance is responsible for such reporting according to the above definition. Data on general government expenditures should be reported within four weeks after the end of the quarter.

\section{Floor on the Net International Reserves of the NBG}

12. Definition: Net international reserves (NIR) of the NBG in U.S. dollars are defined as foreign assets of the NBG minus the sum of foreign liabilities of the NBG. Foreign assets of the NBG include gold, gross foreign exchange reserves, Georgia's SDR holdings, and the reserve position in the IMF. Gross foreign exchange reserves of the NBG are defined as liquid, convertible currency claims of the NBG on nonresidents, including cash holdings of foreign exchange that are readily available. Pledged or otherwise encumbered assets, including (but not limited to) assets used as collateral (or guarantee for third party external liabilities) are excluded from foreign assets. Foreign liabilities of the NBG shall be defined as the sum of Georgia's outstanding liabilities to the IMF, Georgia's SDR allocation, and any other liabilities of the NBG, excluding the foreign exchange balances in the government's account with the NBG. Thus defined, the definition of NIR excludes foreign assets stemming from foreign currency deposits of financial institutions at the NBG and foreign assets arising from the currency swaps with financial institutions. For program monitoring purposes, the stock of foreign assets and foreign liabilities of the NBG shall be valued at program exchange rates as described in paragraph 2 above.

\section{Adjustors:}

The floor on the NIR of the NBG will be adjusted:

- (a) upward/downward by 50 percent for any excess/shortfall in the balance-ofpayments support loans and balance-of-payments support grants relative to the projected amounts presented in Table 2.

- (b) upward/downward by 50 percent for any excess/shortfall in the disbursements of the project loans and project grants to the Treasury Single account at the NBG relative to the projected amounts presented in Table 2. 
- $\quad$ (c) upward by 100 percent for any shortfall in the amount of conversion for government imports relative to the projected amounts presented in Table 2.

- (d) upward by 100 percent for the amount of any Eurobond issuance, net of cost of redemption of previously issued Eurobonds.

14. Supporting material: Data on net international reserves (both at actual and program exchange rates); net foreign financing (balance of payments support loans, cash grants to the general government, amortization (excluding repayments to the IMF), interest payments on external debt by the MOF and the NBG); conversions for government imports and transfers of receipts from the Sovereign Wealth Funds will be provided to the IMF in a foreign exchange cash flow table (which include details of inflows, outflows, and net international reserves) on a weekly basis within three working days following the end of the week.

\section{E. Ceiling on Net Domestic Assets of the NBG}

15. Definition: Net domestic assets of the NBG are defined as the difference between reserve money and NIR as defined above in paragraph 10. Therefore, the ceiling on NDA is defined as projected reserve money (as defined in Table 3) minus the target NIR.

\section{Adjustors:}

The ceiling on the NDA of the NBG will be adjusted:

- (a) upward/downward by 50 percent for any shortfall/excess in the balance-ofpayments support loans and balance-of-payments support grants relative to the projected amounts presented in Table 2 .

- (b) upward/downward by 50 percent for any shortfall/excess in the disbursements of the project loans and project grants to the Treasury Single account at the NBG relative to the projected amounts presented in Table 2.

- $\quad$ (c) downward by 100 percent for any shortfall in the amount of conversion for government imports relative to the projected amounts presented in Table 2 .

- (d) downward by 100 percent for the amount of any Eurobond issuance, net of cost of redemption of previously issued Eurobonds.

17. Supporting material: The NBG will provide to the IMF its balance sheet, which includes data on reserve money and net domestic assets on a weekly basis within three working days following the end of the week. Data will be provided using both actual and program exchange rates. 


\section{F. Ceiling on Contracting or Guaranteeing of New External Debt by the Public Sector}

18. Definition: External debt is defined as set forth in point No. 9 of the Executive Board Decision No. 6230-(79/140), as revised on August 31, 2009 (Decision No. 14416-(09/91)). ${ }^{1}$ External debt is defined as debt contracted by the public sector with nonresidents other than the IMF. Previously disbursed external debt that has been rescheduled will be excluded from the definition of "new debt" for the purposes of this performance criterion.

\section{Adjustor:}

- The end-March 2011 ceiling on contracting or guaranteeing of new external debt by the public sector will be adjusted upward by 100 percent for the amount of any Eurobond issuance.

20. Supporting material: Details of all new contracted debt and government guarantees for external borrowing, with detailed explanations, will be provided by the MOF to the IMF on a quarterly basis within thirty days of the end of each quarter. Data will be provided using actual exchange rates.

\footnotetext{
${ }^{1}$ Point No. 9 of the IMF's guidelines reads as follows: "(a) For the purpose of this guideline, the term "debt" will be understood to mean a current, i.e., not contingent, liability, created under a contractual arrangement through the provision of value in the form of assets (including currency) or services, and which requires the obligor to make one or more payments in the form of assets (including currency) or services, at some future point(s) in time; these payments will discharge the principal and/or interest liabilities incurred under the contract. Debts can take a number of forms, the primary ones being as follows: (i) loans, i.e., advances of money to obligor by the lender made on the basis of an undertaking that the obligor will repay the funds in the future (including deposits, bonds, debentures, commercial loans and buyers' credits) and temporary exchanges of assets that are equivalent to fully collateralized loans under which the obligor is required to repay the funds, and usually pay interest, by repurchasing the collateral from the buyer in the future (such as repurchase agreements and official swap arrangements); (ii) suppliers' credits, i.e., contracts where the supplier permits the obligor to defer payments until sometime after the date on which the goods are delivered or services are provided; and (iii) leases, i.e., arrangements under which property is provided which the lessee has the right to use for one or more specified period(s) of time that are usually shorter than the total expected service life of the property, while the leaser retains the title to the property. For the purpose of the Guideline, the debt is the present value (at the inception of the lease) of all lease payments expected to be made during the period of the agreement excluding those payments that cover the operation, repair, or maintenance of the property. (b) Under the definition of debt set out in point 9(a) above, arrears, penalties, and judicially awarded damages arising from the failure to make payment under a contractual obligation that constitutes debt are debt. Failure to make payment on an obligation that is not considered debt under this definition (e.g., payment on delivery) will not give rise to debt."
} 


\section{G. Continuous Performance Criterion on Accumulation of External Arrears}

21. Definition: External arrears are defined as unpaid debt service by the public sector to official creditors beyond 30 days after the due date.

22. Supporting material: Details of official arrears accumulated on interest and principal payments to creditors will be reported to the IMF within one week from the date of the missed payment. Data will be provided using actual exchange rates.

Table 1. Program Exchange Rates

\begin{tabular}{ccc}
\hline & Currency Name & Currency/US\$ \\
\hline SDR & Special Drawing Rights & 0.65 \\
GEL & Georgian lari & 1.67 \\
EUR & Euro & 0.72 \\
& & \\
\hline
\end{tabular}

Table 2. Projected Balance-of-Payments Support Financing 1/ (In millions of U.S. dollars)

\begin{tabular}{|l|c|c|c|}
\hline & $\begin{array}{c}\text { Balance-of-payments support } \\
\text { loans and balance-of- } \\
\text { payments support grants }\end{array}$ & $\begin{array}{c}\text { Project loans and } \\
\text { project grants }\end{array}$ & $\begin{array}{c}\text { Conversion for } \\
\text { government } \\
\text { imports }\end{array}$ \\
\hline December 31, 2010 & 219.6 & 238.8 & 243.4 \\
\hline March 31, 2011 & 37.7 & 34.7 & 31.0 \\
\hline 1/ Cumulative from the beginning of the calendar year.
\end{tabular}

\begin{tabular}{|l|c|}
\hline \multicolumn{2}{|c|}{$\begin{array}{c}\text { Table 3. Projected Reserve Money } \\
\text { (End-of-period stock in millions of lari) }\end{array}$} \\
\hline December 31, 2010 & $1,918.3$ \\
\hline March 31, 2011 & $1,781.4$ \\
\hline
\end{tabular}




\section{GEORGIA}

Seventh and Eighth Reviews Under the Stand-By Arrangement, and Requests for Waivers of Nonobservance of Performance Criteria and Rephasing of Purchases

\section{Informational Annex}

Prepared by the Middle East and Central Asia Department

December 23, 2010

Contents

I. Relations with the Fund .$\underline{2}$

II. Relations with the World Bank ……………….............................................

III. Relations with the EBRD ........................................................................... 


\section{ANNEX I. GEORGIA: RELATIONS WITH THE FUND}

(As of November 30, 2010)

I. Membership Status: Georgia joined the Fund on May 5, 1992.

II. General Resources Account:

Quota

Fund holdings of currency

Reserve position in Fund

III. SDR Department:

Holdings

IV. Outstanding Purchases and Loans:

Stand-by Arrangements

$\mathrm{ECF}^{1}$

V. Latest Financial Arrangements:

\begin{tabular}{|c|c|c|c|c|}
\hline Type & $\begin{array}{c}\text { Approval } \\
\text { Date }\end{array}$ & $\begin{array}{c}\text { Expiration } \\
\text { Date }\end{array}$ & $\begin{array}{l}\text { Amount Approved } \\
\text { (SDR million) }\end{array}$ & $\begin{array}{l}\text { Amount Drawn } \\
\text { SDR Million) }\end{array}$ \\
\hline tand-By & $9 / 15 / 08$ & 6/14/11 & 747.10 & 577.10 \\
\hline $\mathrm{CF}^{1}$ & $6 / 4 / 04$ & $9 / 30 / 07$ & 98.00 & 98.00 \\
\hline $\mathrm{ECF}^{1}$ & $1 / 12 / 01$ & $1 / 11 / 04$ & 108.00 & 49.50 \\
\hline
\end{tabular}

VI. Projected Payments to Fund (Expectation Basis):

(SDR million; based on existing use of resources and present holdings of SDRs):

\begin{tabular}{cccrrr} 
& \multicolumn{5}{c}{ Forthcoming } \\
\cline { 2 - 6 } & $\mathbf{2 0 1 0}$ & $\mathbf{2 0 1 1}$ & $\mathbf{2 0 1 2}$ & $\mathbf{2 0 1 3}$ & $\mathbf{2 0 1 4}$ \\
Principal & 1.40 & 38.11 & 159.90 & 251.11 & 166.75 \\
Charges/interest & & 10.50 & 9.17 & 5.20 & 1.98 \\
Total & 1.40 & 48.61 & 169.07 & 256.32 & 168.73
\end{tabular}

\section{Safeguard Assessments:}

An update of the December 2008 safeguards assessment of the National Bank of Georgia (NBG) was completed on January 21, 2010 in conjunction with an augmentation of access

\footnotetext{
${ }^{1}$ Following the Low Income Countries (LIC) reforms, effective January 7, 2010, the PRGF arrangements were renamed the Extended Credit Facility (ECF) Arrangements.
} 
under the SBA approved on August 6, 2009. The NBG continues to publish financial statements that comply with International Financial Reporting Standards, and are externally audited by an international firm in accordance with International Standards on Auditing. In response to the safeguards assessment, the authorities have agreed to a multi-year appointment of an external audit firm, beginning with financial year 2010 .

\section{Implementation of Multilateral Debt Relief Initiative (MDRI):}

Not Applicable.

\section{Implementation of HIPC Initiative:}

Not Applicable.

\section{Exchange Arrangements:}

(a) From 1993 to 2009, the National Bank of Georgia conducted foreign exchange market interventions through daily fixing sessions at the Tbilisi Interbank Currency Exchange (TICEX). A temporary de facto exchange rate peg to the U.S. dollar was introduced in the wake of the early August armed conflict. During the second week of November, the authorities allowed a 17 percent depreciation of the lari. In March 2009, the authorities introduced an auction-based system for the foreign exchange market. This mechanism is intended to allow more flexibility and give market forces a greater role in setting the price, with a view to reaching faster and smoother convergence toward equilibrium in the foreign exchange market and giving the market greater clarity about the authorities' policies. In endMay 2009, the authorities officially ended foreign exchange market interventions on TICEX.

(b) The government uses the official exchange rate for budget and tax accounting purposes as well as for all payments between the government and enterprises and other legal entities. The official rate may differ by more than two percent from freely determined market rates, which gives rise to a multiple currency practice. In practice, the official and market rates have never differed by more than 2 percent since the introduction of foreign exchange auctions in March 2009.

\section{Article IV Consultation:}

The 2009 Article IV consultation was concluded on March 23, 2009.

\section{FSAP Participation:}

Two FSAP missions visited Tbilisi during May 1-15, and July 24-August 7, 2001. An FSAP update mission visited Tbilisi during February 15-28, 2006.

\section{Technical Assistance:}

See Table 1 of this Annex. 


\section{Resident Representative:}

The sixth resident representative, Mr. Edward Gardner, took up his post on March 15, 2009.

\section{National Bank of Georgia Resident Advisors:}

Ms. Vance, MAE peripatetic banking supervision advisor to the NBG, commenced a series of visits to Tbilisi in September 1997. Mr. Nielsen, an MAE advisor, provided technical assistance to the NBG in May 1998. Mr. Viksnins was an MAE peripatetic advisor to the NBG president starting in October 1999. Mr. Fish was resident advisor on banking supervision from August 10, 1999 to January 31, 2002. Mr. Bernard Thompson provided peripatetic technical assistance in accounting and internal audit in March and August 2000. Mr. Wellwood Mason provided technical assistance on payment system issues on a peripatetic basis in 2002 and 2003. Mr. Howard C. Edmonds served from September 2004 to October 2007 as a resident advisor on banking supervision issues.

\section{Ministry of Finance Resident Advisors:}

Mr. Sharma was an FAD resident advisor and assisted the authorities in the development of a Treasury beginning in May 1997. Mr. Sainsbury, an FAD advisor, assisted the ministry of finance from June 1998 to November 1999. Mr. Chaturvedi was FAD resident advisor in 2001 and 2002 to assist the authorities in continuing the development of the Treasury and the Treasury Single Account, in revising the legislative framework, expenditure control systems, and budgeting issues. Between 2001 and 2003, Mr. Welling was an FAD peripatetic advisor to assist the State Customs Department in preparing and introducing measures for the custom reform and modernization program. In March 2005, Mr. Zohrab started advising the authorities on treasury-related reforms, and his term ended in November 2006. 
Table 1. Georgia: Fund Technical Assistance Missions, 2007-10

\begin{tabular}{|c|c|c|c|}
\hline Subject & Type of Mission & Timing & Counterpart \\
\hline \multicolumn{4}{|c|}{ Fiscal Affairs Department (FAD) } \\
\hline Tax Administration & Follow-up mission & Jan. 17-30, 2007 & Ministry of Finance \\
\hline Tax Administration & $\begin{array}{l}\text { Expert assistance } \\
\text { (Woodley) }\end{array}$ & $\begin{array}{l}\text { Jan/Feb and Apr/May } \\
2008\end{array}$ & Ministry of Finance \\
\hline $\begin{array}{l}\text { Budget Classification } \\
\text { and Accounting } \\
\text { Reforms }\end{array}$ & $\begin{array}{l}\text { Expert assistance } \\
\text { (Swarap) }\end{array}$ & Jun. 11-22, 2007 & Ministry of Finance \\
\hline $\begin{array}{l}\text { Budget Classification } \\
\text { and Accounting } \\
\text { Reforms }\end{array}$ & $\begin{array}{l}\text { Expert assistance } \\
\text { (Swarap) }\end{array}$ & Jun. 11-22, 2007 & Ministry of Finance \\
\hline $\begin{array}{l}\text { Public Financial } \\
\text { Management }\end{array}$ & Expert assistance & Apr. 6-19, 2010 & Ministry of Finance \\
\hline
\end{tabular}

\section{Monetary and Capital Markets Department (MCM)}

Monetary
Operations/Monetary
Policy/Foreign
Exchange
Consolidated
Supervision
Lender of Last Resort
Framework

Advisory

Advisory

Advisory

Advisory

Foreign Exchange

Market

Macroeconomic

Modeling for Monetary

Policy Formulation

Macroeconomic

Modeling for Monetary

Policy Formulation

Balance of Payments

Monetary and

Financial Statistics

Evaluation of

Technical Assistance

External Sector Statistics

Advisory

Advisory

Advisory
Feb. 16-Mar. 2, National Bank of Georgia 2007

Dec. 4-14, $2007 \quad$ National Bank of Georgia

Dec. 11-17, $2008 \quad$ National Bank of Georgia

Apr. 21-30, $2009 \quad$ Financial Supervisory

Agency; National Bank of Georgia

June 2-10, 2010

National Bank of Georgia

October 4-13, 2010

National Bank of Georgia

\section{Statistics Department (STA)}

Follow-up assistance Jul. 9-20, 2007

Mar. 18-31, 2009

National Bank of Georgia

National Bank of Georgia

Follow-up assistance Jul. 14-16, 2010

National Statistics Office, National Bank of Georgia, Ministry of Finance

National Bank of Georgia 
Table 1. Georgia: Fund Technical Assistance Missions, 2007-10

\begin{tabular}{llll}
\hline Subject & Type of Mission & Timing & Counterpart \\
\hline \multirow{2}{*}{$\begin{array}{l}\text { Legal Department (LEG) } \\
\text { Payment Systems }\end{array}$} & Advisory & May 25-Jun. 5, & National Bank of Georgia \\
Payment Systems & Follow-up assistance & Nov. 8-14, 2010 & National Bank of Georgia \\
\hline
\end{tabular}


ANNEX II. GeORgia: RELATIONS WITH THE WORLD BANK

(As of September 1, 2010)

\begin{tabular}{|c|c|c|c|}
\hline Title & Product & $\begin{array}{l}\text { Tentative Timing of } \\
\text { Mission }\end{array}$ & $\begin{array}{l}\text { Expected Delivery of } \\
\text { Report }\end{array}$ \\
\hline Bank & $\begin{array}{l}\text { Operations } \\
\text { DPO program, including ongoing policy } \\
\text { dialogue on: } \\
\text { public investment management } \\
\text { program budgeting } \\
\text { social safety nets } \\
\text { tax and customs reforms } \\
\text { trade-related reforms } \\
\text { Public Sector Financial Management } \\
\text { Project Analytical Work } \\
\text { Programmatic PER } \\
\text { Trade Dialogue / Technical Assistance } \\
\text { Programmatic Poverty Assessment }\end{array}$ & $\begin{array}{l}\text { Quarterly } \\
\text { Ongoing } \\
\text { Quarterly } \\
\text { Ongoing } \\
\text { Periodic }\end{array}$ & $\begin{array}{l}\text { Ongoing } \\
\text { End-2010/Mid-2011 } \\
\text { Ongoing } \\
\text { Periodic }\end{array}$ \\
\hline Fund & $\begin{array}{l}\text { Missions and Technical Assistance: } \\
\text { Staff visit on } 2011 \text { budget and } \\
\text { macroeconomic framework update } \\
\text { SBA } 7^{\text {th }} \text { and } 8^{\text {th }} \text { Reviews } \\
\text { SBA } 9^{\text {th }} \text { Review and Art.IV Consultation } \\
\text { SBA } 10^{\text {th }} \text { Review } \\
\text { TA: payments system legal framework, } \\
\text { follow up } \\
\text { TA: Payments system oversight } \\
\text { TA: macroeconomic model for monetary } \\
\text { policy analysis } \\
\quad \text { Analytical work } \\
\text { DSGE model for monetary policy } \\
\text { analysis } \\
\text { Inflation process and forecast } \\
\text { Potential output estimation } \\
\text { Equilibrium exchange rate assessment } \\
\text { International reserve adequacy } \\
\text { assessment }\end{array}$ & $\begin{array}{l}\text { Sept.8-16, } 2010 \\
\text { Oct.26-Nov.5, } 2010 \\
\text { Feb 1-11, } 2011 \\
\text { Mar.30-Apr.8, } 2010 \\
\text { January, } 2011 \\
\text { undecided } \\
\text { Oct.4-14, } 2010\end{array}$ & $\begin{array}{l}\text { Sept 20, } 2010 \\
\text { Nov.10 (draft) } \\
\text { Feb } 16 \text { (draft) } \\
\text { Apr.12 (draft) } \\
\text { February } 2011 \\
\text {... } \\
\text { November } 2010\end{array}$ \\
\hline $\begin{array}{l}\text { Joint } \\
\text { Bank- } \\
\text { Fund }\end{array}$ & Joint Debt Sustainability Analysis & & February 2011 \\
\hline
\end{tabular}




\section{ANNEX III. GEORGIA: RELATIONS WITH THE EBRD}

(As of December 15, 2010)

Since 1994, the EBRD has been active in supporting Georgia's transformation toward a market economy. The Bank's current country strategy for Georgia, approved in February 2010, outlines the following main strategic directions:

- Supporting stabilization and restructuring of the financial sector, strengthening risk and portfolio management practices and increasing the share of local currency operations;

- Helping rehabilitate and modernize the country's road, energy and municipal infrastructure to strengthen energy security and promote energy efficiency, help Georgia benefit from its potential as a transit country and improve efficiency and long-term financial sustainability of its municipal services;

- Provide financing to the enterprise sector with the view of supporting innovation, competition and export potential, in particular in manufacturing and agribusiness.

As of end-November 2010, the Bank had signed 131 investments in Georgia with the cumulative commitment totaling $€ 1$ billion. Its outstanding portfolio stands at around $€ 700$ million. The majority of the portfolio is in the financial sector (around $2 / 5^{\text {th }}$ ), energy sector and infrastructure $\left(1 / 5^{\text {th }}\right.$ each). The ratio of private sector projects in the portfolio currently stands at 80 percent. The Bank will give preference to non-sovereign operations. Where sovereign guarantees are required, donor co-funding on a grant basis will be sought.

In 2008-9, the Bank played an important role in stabilizing Georgia's financial system that had suffered from the August 2008 conflict and the global financial crisis. Along with the IFC, the EBRD provided Bank of Georgia and TBC Bank, the two largest systemic banks, with equity, quasi equity and loan facilities aggregating $\$ 170$ million.

In 2010, the EBRD's operations focused on the infrastructure sector. The Bank signed several large projects, including Tbilisi Railway By-Pass ( $€ 112$ million), a sovereign guaranteed loan to finance the Black Sea Transmission Line ( $€ 80$ million), the second stage of the rehabilitation of the Enghuri hydro power plant ( $€ 20$ million) as well as a berth rehabilitation project at the Poti port (€8 million) and Adjara solid waste landfill project (€3million).

The Bank also signed a number of smaller projects in the financial and industrial sectors. The Bank increased its equity participation in Bank Republic and provided SME credit lines to TBC Bank and Bank of Georgia ( $€ 5.6$ million and $€ 15$ million, respectively). It enhanced its Medium size Co-Financing Facility (MCFF) and signed four sub-projects in the manufacturing, agriculture and health sectors (totaling $€ 16$ million). MCFF has been working successfully for several years. The Bank also expanded the efforts in promoting its 
Energy Efficiency Initiative by providing $€ 3.7$ million facility for residential and industrial on-lending to Bank of Georgia.

Georgia is part of the 'Early Transition Countries' (ETC) initiative. Launched in April 2004, the initiative aims to increase investments in the Bank's then seven poorest countries. The initiative builds on international efforts to address poverty in these countries. Through this initiative, the EBRD focuses its efforts on private sector business development and selected public sector interventions. It aims to stimulate market activity by using a streamlined approach to financing, focusing on smaller projects, mobilizing more investment, and encouraging ongoing economic reform. The Bank will accept higher risk in the projects it finances in the ETCs, while respecting the principles of sound banking. Since the launch of the ETC initiative, the Bank's annual business volume in Georgia has increased five-fold.

Going forward, the EBRD is actively engaged in promoting local currency lending and dedollarisation of the Georgian banking system. Georgia is one of the first countries to undergo a joint EBRD-IMF-World Bank assessment of the economic policy, regulatory and legal frameworks for development of the local currency capital markets. Next steps are expected to include a framework agreement with the authorities on policy reforms required to support dedollarisation, expansion of EBRD lending in lari and technical assistance activities. 


\section{Statement by the Staff Representative on Georgia \\ Executive Board Meeting \\ January 12, 2011}

1. The following information has become available since the issuance of the staff report (EBS/10/244). These developments do not change the thrust of the staff appraisal.

Georgia: Quantitative Performance Criteria (PC) and Indicative Targets, 2010

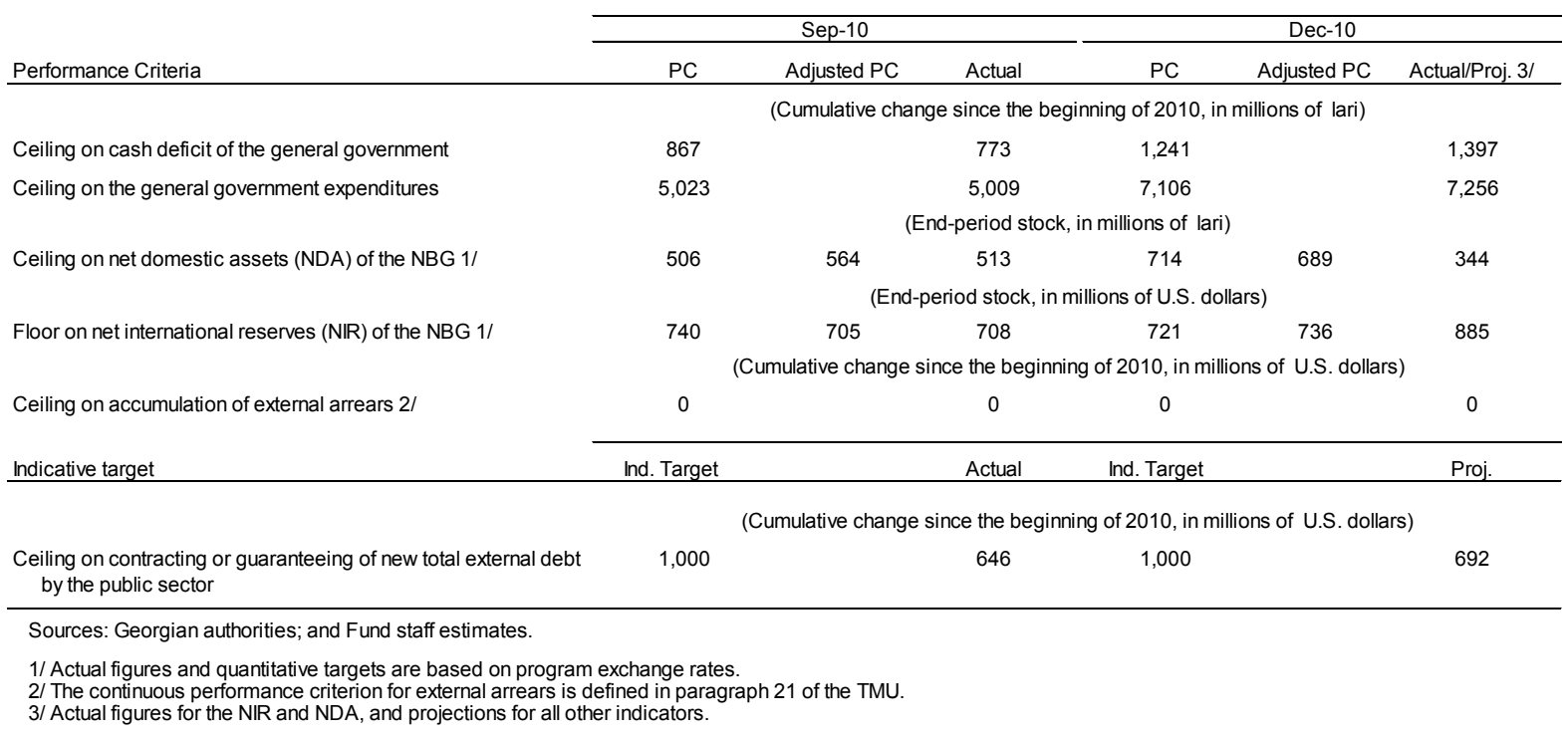

2. The end-December NDA and NIR PCs were met by even larger margins than anticipated reflecting the absence of seasonal intervention in December, which the central bank had anticipated. The level of new external debt contracted or guaranteed by the public sector is expected to be within the ceiling set as an indicative target.

3. The authorities expect government expenditure at end-December 2010 to be slightly higher, by GEL 24 million ( 0.1 percent of GDP), than projected in the staff report owing to a faster pace of capital project implementation by local governments. Since this revision reflects changes in the implementation schedule of projects that have been budgeted, it should in principle be offset by lower capital spending in 2011, and therefore not affect the underlying fiscal stance. At the same time, the authorities noted that this is still a projection and therefore subject to possible deviations. In order to cover such uncertainty and minimize the risk of misreporting, staff and the authorities agreed to adjust upward the projected level of spending by a total of GEL 50 million ( 0.2 percent of GDP) relative to the staff report, as reflected in the above table. Because of better-than-anticipated performance on the revenue side, a similar adjustment is not being sought for the deficit projection. The budget deficit PC is still expected to be missed as set out in the staff report. 
4. Real GDP growth was 6.5 percent year-on-year in the first three quarters of 2010, in line with the annual projection of 6.3 percent. CPI inflation reached 11.2 percent at end-2010, fueled by rising food prices.

5. The authorities have indicated that they do not intend to draw under the arrangement at this time, reflecting improved balance of payments conditions, and the fact that gross international reserves are expected to be further boosted by a return to the market in the near future. 
January 12, 2011

\section{IMF Executive Board Completes Seventh and Eighth Reviews Under the Stand-By Arrangement for Georgia, Approves US\$153 Million Disbursement}

The Executive Board of the International Monetary Fund (IMF) today completed the seventh and eighth reviews of Georgia's economic performance under a Stand-By Arrangement (SBA) for an amount equivalent to SDR 477.1 million (about US\$728 million1) approved on September 15, 2008 (see Press Release No. 08/208). On August 6, 2009, the Executive Board approved an augmentation of access under the SBA to an amount equivalent to SDR 747.1 million (about US\$1 billion) and an extension of the SBA until June 14, 2011 (see Press Release No. 09/277).

The completion of the seventh and eighth reviews allows for the immediate disbursement of an amount equivalent to SDR 100 million (about US\$153 million). In completing the review the Executive Board granted waivers for the nonobservance of the end-December 2010 performance criteria on the cash deficit of the consolidated government and total expenditures of the general government. The Executive Board also approved the rephasing of the remaining disbursements under the SBA.

The authorities indicated that they do not intend to draw the amounts (SDR 100 million) that became available to Georgia after the completion of the seventh and eight reviews.

After the Executive Board's discussion, Mr. Murilo Portugal, Deputy Managing Director and Acting Chair, said:

"Backed by the steady implementation of the program's economic policies, Georgia's economic recovery has strengthened, as evidenced by better-than-expected growth and the stabilization of the exchange rate. The authorities' economic policies, focused on tighter monetary and fiscal policies and exchange rate flexibility, will lay the groundwork for achieving macroeconomic stability and growth based on private sector financing and investment. While short-term risks to growth appear balanced, significant downside mediumterm external risks remain, related in particular to the uncertainty surrounding the recovery in private capital inflows, including FDI.

Washington, D.C. 20431 • Telephone 202-623-7100 • Fax 202-623-6772 • www.imf.org 
"The budget for 2011, which provides for a further reduction of the deficit of about $2 \frac{1}{2}$ percent of GDP, is consistent with the authorities' objective of reestablishing fiscal sustainability. The authorities' commitment to cap expenditure in 2011 is commendable, as is their decision to introduce an escape clause in the constitutional amendment subjecting tax increases to a referendum. This clause will provide the authorities with more flexibility in implementing the consolidation efforts necessary over the medium term.

"While the recent increase in the policy rate and the decision to tighten reserve requirements will help to bring down inflation in 2011, the authorities should stand ready to tighten monetary policy further should inflationary pressures persist. Consistent with the need to rebuild net international reserves, exchange rate flexibility should remain an anchor of the authorities' economic strategy.

"The banking sector's high levels of capital and provisioning continue to provide adequate buffers against adverse shocks, but continued close supervision of banks remains critical. In this regard, capacity building toward risk-based supervision is welcome. As announced by the authorities, it is also important to continue tightening the regulatory framework as financial sector stability solidifies." 


\section{Statement by Age Bakker, Executive Director for Georgia And David Lezhava, Assistant to Executive Director January 12, 2011}

\section{Economic performance}

2010 can be considered as the recovery year for Georgia. In the first quarter of 2010 estimates for growth were around 2.0 percent. In the course of the year, GDP growth has accelerated substantially, narrowing the negative output gap. The growth rate in the third quarter reached 6.7 percent with 6.5 percent year-on-year for the first three quarters. Several sectors showed double digit growth: manufacturing, trade, transport, and finance.

Since the sixth review, both the authorities and staff have raised their estimates for growth for 2010. The authorities' projections remain more conservative compared to staff, largely reflecting the preference for upside risks. According to the authorities' latest estimates, the GDP growth rate in 2010 will be close to 6.0 percent.

Increased external demand for goods and services made a significant positive contribution to growth. Export and import of goods and services in the first three quarters grew at 22.8 and 13.7 percent respectively. Distinct annual growth by 1.6 times was observed in tourism services in the third quarter, as a result of infrastructure development. Overall, the current account deficit for the first 9 months of 2010 was $15.6 \%$ less, compared to the same period of 2009.

In the third quarter of 2010 prices started accelerating and inflation now stands at 11.2 percent. Food prices largely contributed to this increase, reflecting low agricultural yields as well as an increase in international food prices. Monetary policy was tightened several times in the second half of the year, but its effect on prices has not materialized yet. However, core annual inflation during the last month fell from 9.7 to 7.6 percent.

Nominal and real exchange rates have appreciated by 2.4 and 0.4 percent during the year. The exchange rate against the dollar depreciated by 4.7 percent during the year. The trend was uneven during the year, with clearly defined depreciation pressures in the first half and appreciation pressures in the period September-November. The appreciation was due to a mix of factors, including an increase in non-resident FX deposits and market expectations.

The authorities used the opportunity to accumulate reserves. As a result, both end-September and end-December NIR targets were met with significant margins. The authorities stand ready to allow exchange rate depreciation, unless extreme volatility or speculative pressures are observed or if too fast and/or too large depreciation threatens financial stability.

Fiscal performance in the first three quarters of 2010 has been stronger than anticipated. There are no final figures yet for Q4, but probably the budget deficit and expenditure ceiling PCs will be missed. Such an outcome is highly probable largely due to unrealized budget grants on the one hand and disbursement for a high voltage power transmission project loan on the other hand, which the authorities had anticipated would be disbursed in 2011, due to 
the conditions they needed to fulfill. Therefore the authorities estimate the amount of general government expenditure to be below 7256 million GEL and the deficit of the general government to be 1397 million GEL. However, the deficit will decline significantly in 2010, to 6.8 percent of GDP from 9.2 percent of GDP in 2009. The fiscal deficit will be reduced further to 4.3 percent of GDP in 2011.

The banking sector indicators continue to show steadily improved performance. ROE and ROA for the entire banking sector for the end of November was 10.7 and 1.9 percent respectively. The banking sector remains highly capitalized, with an average capital adequacy ratio of 18.2 at end-November 2010. Since May non-performing loans have decreased in nominal terms by 13.2 percent. The volume of deposits and bank lending are growing steadily.

\section{Policy response to economic developments}

In response to inflationary pressures the monetary authorities have taken several tightening measures. The monetary policy rate was gradually increased from 5.0 to 7.5 percent, although in a dollarized economy increases in local currency interest rates have become less effective. Therefore, the National Bank extended the coverage of reserve requirements to external borrowing of commercial banks. In addition, as of January 20, 2011 reserve requirements on foreign currency will be increased from 5 to 10 percent as a first step to a planned increase of up to 15 percent.

In order to further strengthen regulatory disincentives for lending in foreign currency and taking into account the recent rapid recovery, the NBG has increased the weight for loans denominated in foreign currency in risk-weighted assets from 1.5 to 1.75 starting from January 1, 2011. Since October the NBG increased the minimum liquidity ratio from 20 to 30 percent, restoring pre-crisis requirements.

The Ministry of Finance is broadly on track in implementing the Public Finance Management Reform Policy Vision 2009-2013. The Reform Action Plan for 2010 is successfully being implemented. Consistent with the new budget code, by end-July 2010 the cabinet endorsed the medium-term expenditure framework that included expenditure ceilings applicable to the 2011 budget (structural benchmark under the program). Also, in October 2010 the cabinet endorsed guidelines for pilot ministries to introduce a programmatic approach to budgeting, in line with the recommendations from the Fiscal Affairs Department's technical assistance (structural benchmark).

A New Tax Code and its regulations are in force from January 1, 2011. An important change in the tax code is simpler taxes for small taxpayers. A number of structural reforms has been implemented by the Revenue Service of the Ministry of Finance. To create a convenient tax payment process the authorities put relevant infrastructure in place and e-services are being implemented. These and many other changes in the system are aimed at the formation of a fair, simple and reliable tax system.

The NBG is implementing a new portfolio management system. The system will be IFRS compliant and will allow the NBG to introduce new, more sophisticated financial instruments 
and investment techniques in its reserves management process. The new system will help the NBG bring its reserves management procedures in line with international best practices. The recently implemented new Real Time Gross Settlement (RTGS) increases both speed and capacity of the transaction system, making it more reliable and allowing for new functions, such as intraday lending. The government has introduced an electronic treasury system. The established direct electronic link has significantly increased the efficiency of interaction between the treasury and all government institutions.

\section{Policies Going Forward}

The authorities consider a sound fiscal position critical for the sustainability of the recovery and also to preserve the stability of Georgia's external accounts. Therefore they are committed to deficit reduction. Based on further expenditure containment, an expected recovery of tax revenues owing to sustained GDP growth as well as the revenue measures taken in 2010 and 2011, the authorities are committed to steady reductions in the deficit to 23 percent of GDP by 2013.

The authorities are not satisfied with the current FDI levels. An increase is needed in order to foster high sustainable growth. The authorities are implementing reforms to eliminate structural constraints. Thanks to the reforms conducted in the last few years, Georgia is ranked number 12 in the ease of doing business. A recent unilateral initiative to declare that Georgia will never use force for the country's reunification should facilitate normalization of the political climate. During the year rating agencies have upgraded Georgia's rating. All this together with global recovery prospects strengthens confidence that FDI can be increased.

One of the most actively discussed issues in the Executive Board during the preceding reviews was the authorities' decision to make tax increases subject to referendums. This constitutional amendment now has been adopted, but with the introduction of an escape clause. The conditions under which the referendum requirement would be suspended will be defined by the Economic Freedom Act, which will be resubmitted to parliament in 2011.

Monetary policy will aim at bringing year-on-year inflation back towards the 6-percent target by end-2011, while fostering investor confidence through increases in gross and net international reserves. Due to the cooperation between the monetary and fiscal authorities containing inflation within sustainable limits is guaranteed. Dedollarization remains one of the main objectives of the monetary authorities. They realize that a successful dedollarisation process is a precondition for the efficiency of monetary policy in the future.

As was mentioned above, economic developments allowed the National Bank to build up some international reserves. According to the BOP forecasts the National Bank will be able to further add to reserves. The authorities do not see an urgent need to draw from the Fund at the moment. Therefore, the authorities will maintain a close policy dialogue with the Fund and stand ready to take additional measures as appropriate to ensure that we meet the program objectives. 